\title{
Nutritional evaluation of lowering consumption of meat and meat products in the Nordic context
}

Tetens, Inge; Hoppe, Camilla ; Frost Andersen, Lene ; Helldan, Anni; Warensjö Lemming, Eva; Trolle, Ellen; Holm Totland, Torunn; Lindross, Anna Karin

Link to article, DOI:

10.6027/TN2013-506

Publication date:

2013

Document Version

Publisher's PDF, also known as Version of record

Link back to DTU Orbit

Citation (APA):

Tetens, I., Hoppe, C., Frost Andersen, L., Helldan, A., Warensjö Lemming, E., Trolle, E., Holm Totland, T., \& Lindross, A. K. (2013). Nutritional evaluation of lowering consumption of meat and meat products in the Nordic context. Nordic Council of Ministers. TemaNord No. 2013:506 https://doi.org/10.6027/TN2013-506

\section{General rights}

Copyright and moral rights for the publications made accessible in the public portal are retained by the authors and/or other copyright owners and it is a condition of accessing publications that users recognise and abide by the legal requirements associated with these rights.

- Users may download and print one copy of any publication from the public portal for the purpose of private study or research.

- You may not further distribute the material or use it for any profit-making activity or commercial gain

- You may freely distribute the URL identifying the publication in the public portal 


\section{U norden}

\section{Nutritional evaluation of lowering consumption of meat and meat products in the Nordic context}

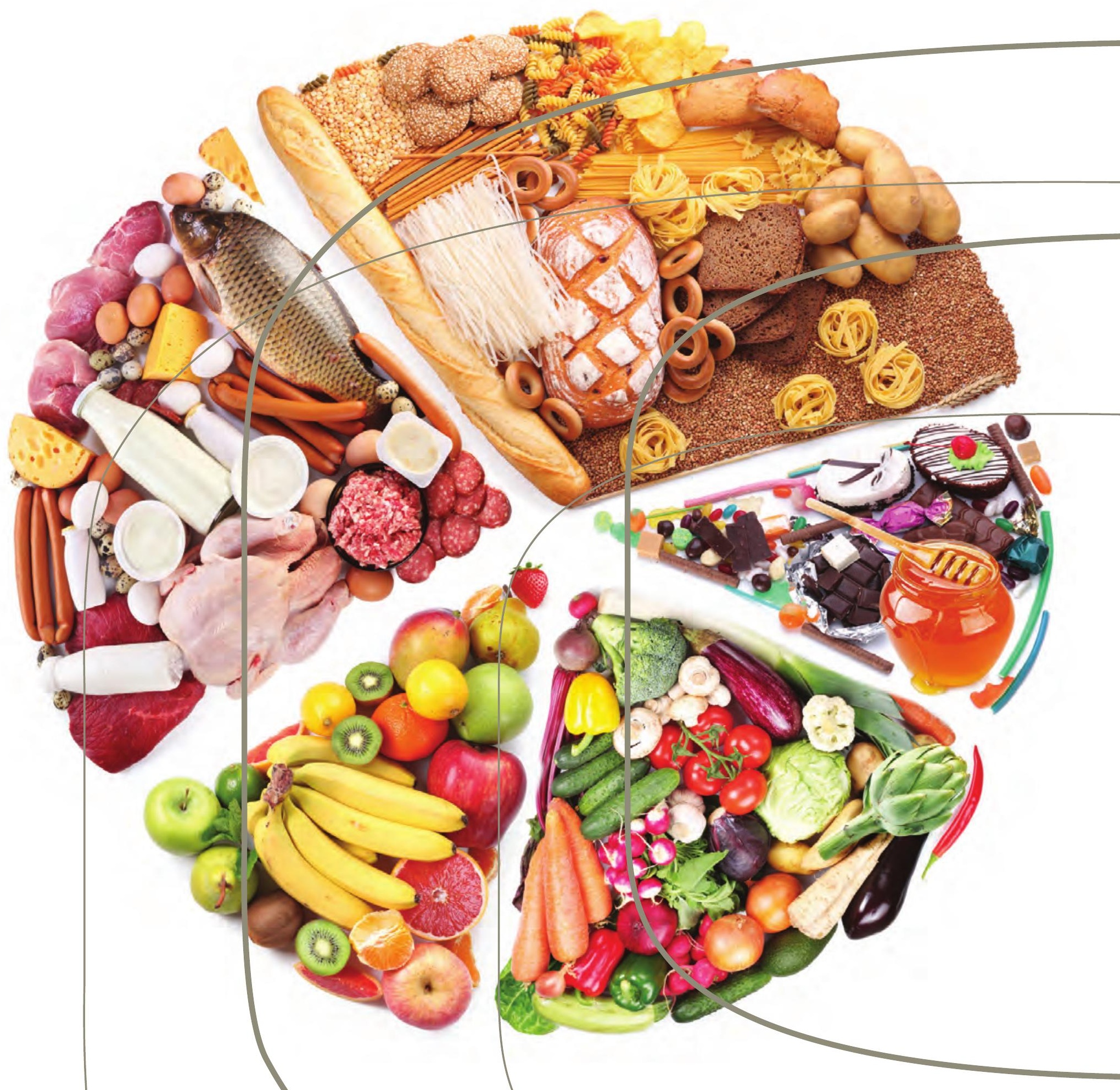



2 norden 



\section{Nutritional evaluation of lowering consumption of meat and meat products in the Nordic context}

Inge Tetens, Camilla Hoppe, Lene Frost Andersen, Anni Helldán, Eva Warensjö Lemming, Ellen Trolle. Torunn Holm Totland and Anna Karin Lindroos 
Nutritional evaluation of lowering consumption of meat and meat products in the Nordic context

Inge Tetens, Camilla Hoppe, Lene Frost Andersen, Anni Helldán, Eva Warensjö Lemming,

Ellen Trolle. Torunn Holm Totland and Anna Karin Lindroos

ISBN 978-92-893-2465-6

http://dx.doi.org/10.6027/TN2013-506

TemaNord 2013:506

(C) Nordic Council of Ministers 2013

Layout: NMR

Cover photo: ImageSelect

This publication has been published with financial support by the Nordic Council of Ministers. However, the contents of this publication do not necessarily reflect the views, policies or recommendations of the Nordic Council of Ministers.

\section{www.norden.org/en/publications}

\section{Nordic co-operation}

Nordic co-operation is one of the world's most extensive forms of regional collaboration, involving Denmark, Finland, Iceland, Norway, Sweden, and the Faroe Islands, Greenland, and Åland.

Nordic co-operation has firm traditions in politics, the economy, and culture. It plays an important role in European and international collaboration, and aims at creating a strong Nordic community in a strong Europe.

Nordic co-operation seeks to safeguard Nordic and regional interests and principles in the global community. Common Nordic values help the region solidify its position as one of the world's most innovative and competitive.

\section{Nordic Council of Ministers}

Ved Stranden 18

DK-1061 Copenhagen K

Phone (+45) 33960200

www.norden.org 


\section{Content}

Preface

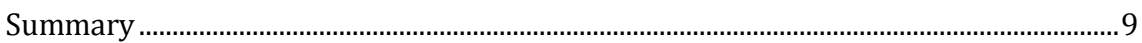

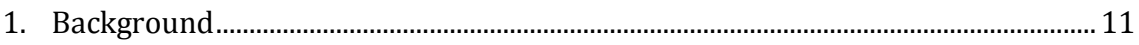

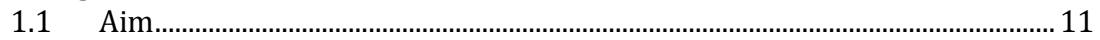

2. Meat products and constituents............................................................................ 13

2.1 Contributions from meat to energy and nutrients in the Nordic diets........... 14

2.2 Trends in the supply of meat and meat products .......................................... 17

3. Materials and Methods ......................................................................................... 21

3.1 Description of estimation of meat intake in the participating countries.............................................................................................................. 21

3.2 Manual for the modelling exercise ……………............................................. 27

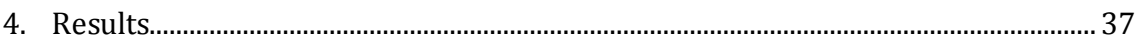

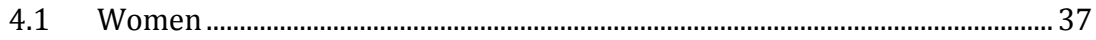

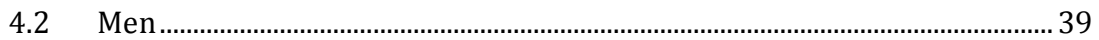

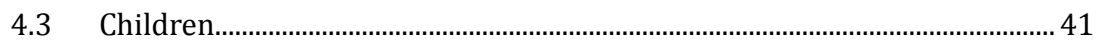

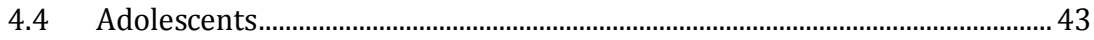

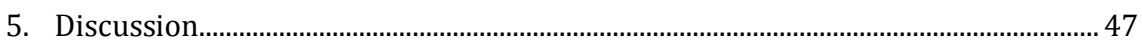

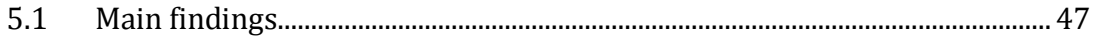

5.2 Intake of meat and meat products and health ............................................... 48

5.3 Intake of meat and meat products and nutrients........................................... 49

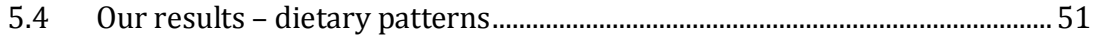

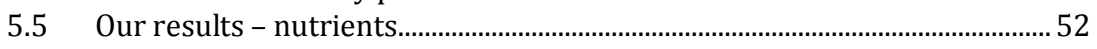

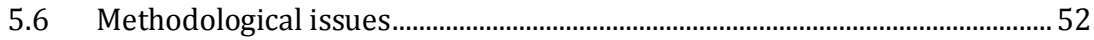

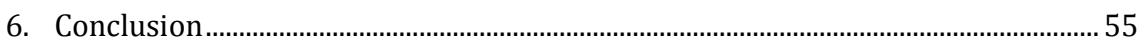

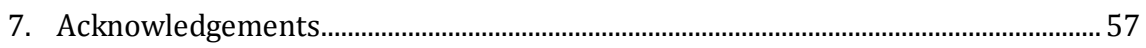

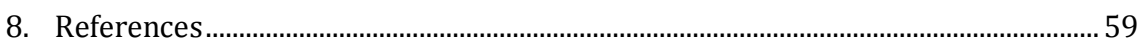

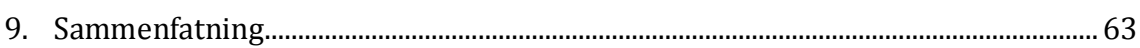

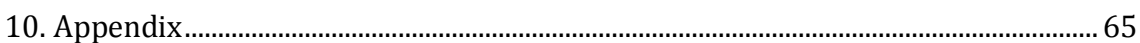

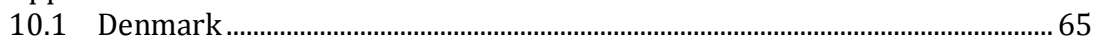

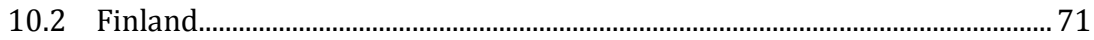

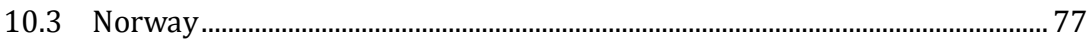

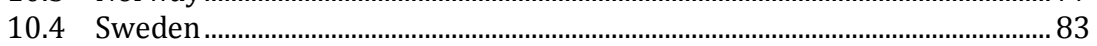





\section{Preface}

In recent years the role of meat as an important part of the diet has been challenged. Not only with regard to animal welfare, climate and environmental changes but also in relation to health issues.

Quantitative guidelines about optimal amounts of meat and meat products in the habitual diet should be based on estimations on the actual diets. The Nordic countries conduct representative national dietary surveys that can serve as a base for estimating the nutritional consequences of changes in meat intake.

The Nordic Council of Ministers provided funding via a grant from the Nordic Working Group for Diet, Food and Toxicology (NKMT) to four Nordic countries to conduct a modeling study on the nutritional consequences of change in the current habitual intake of meat and meat products. The present report is the result of this study. The study was headed by the National Food Institute, Technical University of Denmark (Inge Tetens, Camilla Hoppe, Ellen Trolle) with participation from Institute of Basic Medical Sciences, University of Oslo, Norway (Lene Frost Andersen, Torunn Holm Totland), National Food Agency, Sweden (Anna Karin Lindroos , Eva Warensjö Lemming), and National Institute for Health and Welfare, Finland (Anni Helldán).

Søborg November 28th, 2012,

\section{Gitte Gross}

Head of Division of Nutrition, The National Food Institute,

Technical University of Copenhagen 



\section{Summary}

Based on a systematic review of the available literature and in particular with reference to the evidence on the association between colorectal cancer and meat consumption, The World Cancer Research Fund (WCRF) recommended in 2007 that the dietary intake on red meat should be limited and processed meat avoided. The personal recommendation to individuals consuming meat was to consume less than 500 g red meat per week (equivalent to $70 \mathrm{~g} / \mathrm{d}$ ) with very little - if any processed meat. The specific public health goal was an average consumption of red meat to be no more than $300 \mathrm{~g}$ of red meat per week (equivalent to $43 \mathrm{~g} / \mathrm{d}$ ) and very little - if any processed meat.

The aim of this report was to assess the overall nutritional consequences of lowering the daily consumption of meat from current intake to the level suggested by the WCRF, with specific emphasis on processed meat.

Five scenarios were generated, and dietary modeling was conducted for each of the four Nordic countries for women 18-75 y, men 18-75y, children 4-9 y, and adolescents 10-17 y. Scenario 1 was the average habitual diet; Scenario 2 was the average habitual diet where the habitual red meat intake was reduced to $70 \mathrm{~g} / \mathrm{d}$ and the intake of processed meat intake was $0 \mathrm{~g} / \mathrm{d}$. The meat was substituted with $\mathrm{X} g$ white meat/fish; Scenario 3 was the average habitual diet where the habitual red meat intake was reduced to $70 \mathrm{~g} / \mathrm{d}$ and the intake of processed meat intake was $0 \mathrm{~g} / \mathrm{d}$. The meat was substituted with a proportional amount of other food products but meat; Scenario 4 the average habitual diet where the habitual red meat intake was reduced to $43 \mathrm{~g} / \mathrm{d}$ and the intake of processed meat intake was $0 \mathrm{~g} / \mathrm{d}$. The meat was substituted with $\mathrm{X} \mathrm{g}$ white meat/fish; and Scenario 5 was the average habitual diet where the habitual red meat intake was reduced to $43 \mathrm{~g} / \mathrm{d}$ and the intake of processed meat intake was $0 \mathrm{~g} / \mathrm{d}$. The meat was substituted with a proportional amount of other food products but meat.

The present study showed that the average meat intake in the Nordic countries in 18-75-y-old women and men, 4-9-y-old children, and 10-17$y$-old adolescents was not very high in comparison with the levels recommended by the WCRF. The largest change observed in the modelling of the dietary intake to the levels recommended by the WCRF was the exclusion of processed meat. 
The overall impact on the average intake of nutrients that should be limited in the diet and on the nutrients that should be increased in the diet in relation to the nutrition recommendations differed little in the different scenarios studied, where white meat and fish or other food items substituted red meat and processed meat.

Despite methodological challenges when comparing nutritional data from representative samples from four different countries, results were markedly similar across countries

The present study suggests that the current habitual level of intake of meat is not far from the level suggested by WCRF at individual level. The greatest difference was the reduction in processed meat, with neglectable nutritional consequences of this reduction. 


\section{Background}

Based on a systematic review of the available literature and in particular with reference to the evidence on the association between colorectal cancer and meat consumption, The World Cancer Research Fund (WCRF) recommended in 2007 that the dietary intake on red meat should be limited and processed meat avoided (World Cancer Research Fund and American Institute for Cancer Research, 2007). The personal recommendation to individuals consuming meat was to consume less than $500 \mathrm{~g}$ red meat per week (equivalent to $70 \mathrm{~g} / \mathrm{d}$ ) with very little - if any - processed meat. The specific public health goal was an average consumption of red meat to be no more than $300 \mathrm{~g}$ of red meat per week (equivalent to $43 \mathrm{~g} / \mathrm{d}$ ) and very little - if any processed meat. Amounts are for weigt of meat as eaten.

In the Nordic countries meat and meat products are part of the traditional diets and contribute protein, readily available iron (heme iron), zinc, selenium and a range of B-vitamins. Meat also provides fat, especially saturated fatty acids in varying amount depending on the animal species and the specific cut from the animal and on the processing. Processed meat products may contain relatively high amounts of sodium (as salt). Like in other countries each of the Nordic countries has its own food based dietary guidelines (FGDG). However, until the recent Norwegian FBDG (Nasjonalt råd for ernæring, 2011), none of the Nordic countries had specific guidelines regarding the amounts of meat or meat products as part of the existing FBDG. In order to form the basis for future guidelines on meat intake, work is needed to estimate the nutritional consequences of a change of the present meat intake to the level suggested by the WCRF or to other levels.

\subsection{Aim}

The aim of this report was to assess the overall nutritional consequences of lowering the daily consumption of meat from current intake to the level suggested by the The World Cancer Research Fund, with specific emphasis on processed meat. 



\section{Meat products and constituents}

In this report the term meat includes all animal flesh from mammals and birds. The term red meat refers to flesh from beef, pork, lamb and goat. The term white meat refers to meat from poultry like chicken and turkey. The term meat products include food items that completely or partially are prepared by meat ingredients with the exception of whole, coherent meat pieces. The term processed meat is used in relation to meat and meat products that are salted, smoked, or treated in any other way in order to prolong the shelf life. Meat and meat products that are temperature treated (freezing or cooking) is not regarded as processed meat in this context (World Cancer Research Fund and American Institute for Cancer Research, 2007).

Meat usually contains $20-35 \%$ protein (weight basis). Meat and meat products can be important sources of vitamin $\mathrm{B}_{6}$, vitamin $\mathrm{B}_{12}$, iron, zinc and selenium. There are large differences between different meat sources and meat products concerning content of energy, fat, fatty acids, and salt (Table 1). The fat content varies from below $1 \%$ to above $40 \%$. The fatty acid composition also varies between species. The percentage of saturated fatty acids is approximately $30 \%$ of fat content in chicken, $35 \%$ in pork, $45-50 \%$ in lamb and beef. The percentage of trans fatty acids is below $1 \%$ in chicken and pork, and approximately $4 \%$ in ruminants such as beef and lamb. The content of salt is low in raw meat, but is often high in processed meat products (Danish Food Composition Databank, 2012).

Meat from wild animals is usually leaner, contains a larger percentage of polyunsaturated fatty acids and a smaller percentage of saturated fat than meat from domesticated animals. 


\subsection{Contributions from meat to energy and nutrients in the Nordic diets}

Meat and meat products contribute with a number of nutrients to the overall habitual diet. On average meat and meat products contribute with $10-20 \%$ of the intake of fat and monounsaturated fatty acids, protein, vitamin A, several B vitamins, and iron, zinc and selenium in the Danish, Finnish, Norwegian and Swedish diet (Table 2). In Denmark, the contribution of especially fat soluble vitamins from meat is high in comparison to the other Nordic countries. This may be attributed to the relatively high intake of liver paste, which has a high content of vitamin A. Additionally, the intake of fish is lower in Denmark, resulting in a higher contribution of vitamin D from meat in Denmark.

\begin{tabular}{|c|c|c|c|c|c|c|}
\hline & Energy, & Fat, & $\begin{array}{r}\text { Saturated } \\
\text { fat, } \\
\mathrm{g}\end{array}$ & $\begin{array}{r}\text { Mono } \\
\text { un-saturated } \\
\text { fat, } \\
\text { g }\end{array}$ & $\begin{array}{r}\text { Trans } \\
\text { fatty } \\
\text { acids, } \\
\text { g }\end{array}$ & Sodium, \\
\hline \multicolumn{7}{|l|}{ Denmark } \\
\hline Chicken, hen, flesh only & 445 & 2.7 & 0.7 & 0.8 & $<0.1$ & 52 \\
\hline Chicken, breast, boiled, sliced & 475 & 3.2 & 0.8 & 1.1 & $<0.1$ & 1120 \\
\hline Pork, liver paste, Danish, low fat & 636 & 6.7 & 2.2 & 2.3 & $<0.1$ & 802 \\
\hline Lamb, leg, average values, raw & 704 & 9.8 & 4.5 & 3.6 & 0.6 & 66 \\
\hline Pork, collar, defatted, raw & 757 & 12.2 & 4.4 & 5.0 & $<0.1$ & 82 \\
\hline Pork, liver paste, Danish & 989 & 19.2 & 6.7 & 8.0 & $<0.1$ & 718 \\
\hline Bacon, sliced, raw & 1076 & 21.4 & 7.5 & 9.3 & $<0.1$ & 1225 \\
\hline Beef, entrecote, "cap on," raw & 1098 & 21.3 & 9.0 & 10.2 & 0.6 & 54 \\
\hline Pork, sausage, frankfurter & 1144 & 23.2 & 8.4 & 10.7 & $<0.1$ & 1164 \\
\hline Sausage, salami & 2107 & 49.0 & 18.8 & 22.5 & $<0.1$ & 1988 \\
\hline \multicolumn{7}{|l|}{ Sweden } \\
\hline Chicken, breast, boiled & 625 & 4.0 & 1.1 & 1.6 & na & 430 \\
\hline Pork, liver paste, Swedish, low fat & 767 & 9.0 & 3.2 & 3.9 & na & 600 \\
\hline Pork, collar, raw & 717 & 11.2 & 4.9 & 4.6 & na & 57 \\
\hline Chicken, hen, flesh only & 590 & 6.3 & 1.4 & 2.7 & na & 52 \\
\hline Pork, sausage, frankfurter & 1146 & 215 & 7.9 & 10.4 & na & 850 \\
\hline Beef, boiled & 723 & 5.4 & 2.2 & 2.4 & na & 194 \\
\hline Lamb steak, raw & 555 & 5.9 & 3.0 & 2.2 & na & 66 \\
\hline Pork, liver paste, Swedish & 1181 & 23.2 & 8.5 & 10.1 & na & 737 \\
\hline Bacon, sliced, raw & 1441 & 32.8 & 13.7 & 14.8 & na & 820 \\
\hline Sausage, salami imported & 2029 & 45.0 & 16.7 & 20.0 & na & 1850 \\
\hline
\end{tabular}

"na" values are not available 
Table 2. Contribution of energy and macronutrients, vitamins and minerals from meat and poultry in the Danish diet (Pedersen et al., 2010), the Finnish diet (Findiet 2007, unpublished results), the Norwegian diet (Norkost3, 2006), and the Swedish diet (Riksmaten adults unpublished results, 2010) (\% of total intake)

\begin{tabular}{|c|c|c|c|c|c|c|c|c|c|c|}
\hline & \multirow[t]{2}{*}{ Energy } & \multirow[t]{2}{*}{ Fat } & \multicolumn{4}{|c|}{ Fatty acids } & \multirow[t]{2}{*}{ Carbohydrate } & \multirow{2}{*}{$\begin{array}{l}\text { Added } \\
\text { sugar }\end{array}$} & \multirow[t]{2}{*}{ Fibre } & \multirow[t]{2}{*}{ Protein } \\
\hline & & & SFA & MUFA & PUFA & Trans & & & & \\
\hline \multicolumn{11}{|c|}{ Denmark } \\
\hline Meat & 10 & 20 & 18 & 25 & 11 & 11 & - & - & - & 25 \\
\hline Poultry & 2 & 2 & 1 & 2 & 3 & 0 & 0 & 0 & 0 & 6 \\
\hline \multicolumn{11}{|l|}{ Finland } \\
\hline Meat & 9 & 16 & 16 & 18 & 11 & 12 & 0.5 & - & - & 20 \\
\hline Poultry & 2 & 3 & 2 & 4 & 5 & 3 & - & - & - & 7 \\
\hline \multicolumn{11}{|l|}{ Norway } \\
\hline Meat & 6 & 10 & 10 & 12 & 5 & na & - & - & - & 14 \\
\hline Poultry & 2 & 2 & 2 & 2 & 2 & na & - & - & - & 7 \\
\hline \multicolumn{11}{|l|}{ Sweden } \\
\hline Meat & 9 & 16 & 17 & 20 & 13 & na & 1 & 1 & 2 & 16 \\
\hline Poultry & 2 & 3 & 2 & 3 & 2 & na & 0 & 0 & 0 & 6 \\
\hline
\end{tabular}

“_" contribution is less than $0.5 \%$, "na” values are not available 
Table 2 - continued. Contribution of energy and macronutrients, vitamins and minerals from meat and poultry in the Danish diet (Pedersen et al., 2010), the Finnish diet (Findiet 2007, unpublished results), the Norwegian diet (Norkost3), and the Swedish diet (Riksmaten, adults 2010, unpublished results) (\% of total intake)

\begin{tabular}{|c|c|c|c|c|c|c|c|c|c|c|c|c|}
\hline & \multicolumn{5}{|c|}{ Fat soluble vitamins } & \multicolumn{7}{|c|}{ Water soluble vitamins } \\
\hline & Vit A & Retinol & $\beta$-carotene & Vit D & Vit E & Thiamine & Riboflavin & Niacin & Vit $B_{6}$ & Folate & Vit $B_{12}$ & Vit C \\
\hline \multicolumn{13}{|l|}{ Denmark } \\
\hline Meat & 34 & 50 & 0 & 19 & 3 & 31 & 15 & 25 & 19 & 7 & 35 & 6 \\
\hline Poultry & - & - & 0 & 1 & 1 & 2 & 2 & 7 & 5 & 1 & 3 & 1 \\
\hline \multicolumn{13}{|l|}{ Finland } \\
\hline Meat & 1 & 1 & - & 4 & 3 & 24 & 9 & 19 & 19 & 1 & 13 & . \\
\hline Poultry & 1 & 1 & - & 2 & 3 & 2 & 3 & 6 & 18 & 1 & 4 & - \\
\hline \multicolumn{13}{|l|}{ Norway } \\
\hline Meat & 1 & 1 & - & - & 2 & 11 & 7 & na & 10 & 1 & 13 & . \\
\hline Poultry & - & 1 & - & - & 2 & 3 & 3 & na & 10 & 1 & 3 & . \\
\hline \multicolumn{13}{|l|}{ Sweden } \\
\hline Meat & 8 & 11 & - & 9 & 6 & 17 & 14 & 20 & 13 & 3 & 17 & 3 \\
\hline Poultry & 1 & 1 & - & 4 & 4 & 4 & 3 & 9 & 6 & 2 & 1 & 0 \\
\hline
\end{tabular}

"-" contribution is less than $0.5 \%$

\begin{tabular}{|c|c|c|c|c|c|c|c|c|}
\hline & Calcium & Phosphorus & Magnesium & Iron & Zinc & lodine & Selenium & Potassium \\
\hline \multicolumn{9}{|c|}{ Denmark } \\
\hline Meat & 1 & 14 & 6 & 18 & 30 & 1 & 25 & 10 \\
\hline Poultry & . & 3 & 2 & 2 & 3 & 0 & 7 & 2 \\
\hline \multicolumn{9}{|l|}{ Finland } \\
\hline Meat & 1 & 10 & 5 & 11 & 18 & 2 & 24 & 7 \\
\hline Poultry & - & 3 & 2 & 2 & 3 & 2 & 5 & 2 \\
\hline \multicolumn{9}{|l|}{ Norway } \\
\hline Meat & 1 & $\mathrm{Na}$ & 4 & 11 & na & na & na & 6 \\
\hline Poultry & - & $\mathrm{Na}$ & 2 & 1 & na & na & na & 2 \\
\hline \multicolumn{9}{|l|}{ Sweden } \\
\hline Meat & 4 & 15 & 7 & 18 & 27 & na & 15 & 11 \\
\hline Poultry & 0 & 4 & 3 & 2 & 3 & na & 6 & 3 \\
\hline
\end{tabular}

"-_" contribution is less than $0.5 \%, "$ na" values are not available 


\subsection{Trends in the supply of meat and meat products}

\subsubsection{Denmark}

The annual per capita meat supply in Denmark increased during the 1970s and 1980s up to around $110 \mathrm{~kg}$ per capita per year in the $1990 \mathrm{~s}$ and around 2000. Hereafter the meat supply has decreased. The increase was mainly due to the increase in supply of pork in the 1970s and 1980s. The supply of poultry has increased steadily from $3 \mathrm{~kg}$ per capita per year in 1955 to $22 \mathrm{~kg}$ in 2006-2008 while the supply of cattle was almost stable until the increase started in the 1990s. The decrease in the supply of pork started around 2000. It is important to notice that there was a large decrease from 2004 to 2005 in the supply of pork due to changes in data handling. Overall, the recent years show a decrease in supply of in all three types of meat and total meat consumption per capita was $83 \mathrm{~kg}$ in 2009 (Figure 1).

Figure 1. Per capita supply (kg/capita/y)

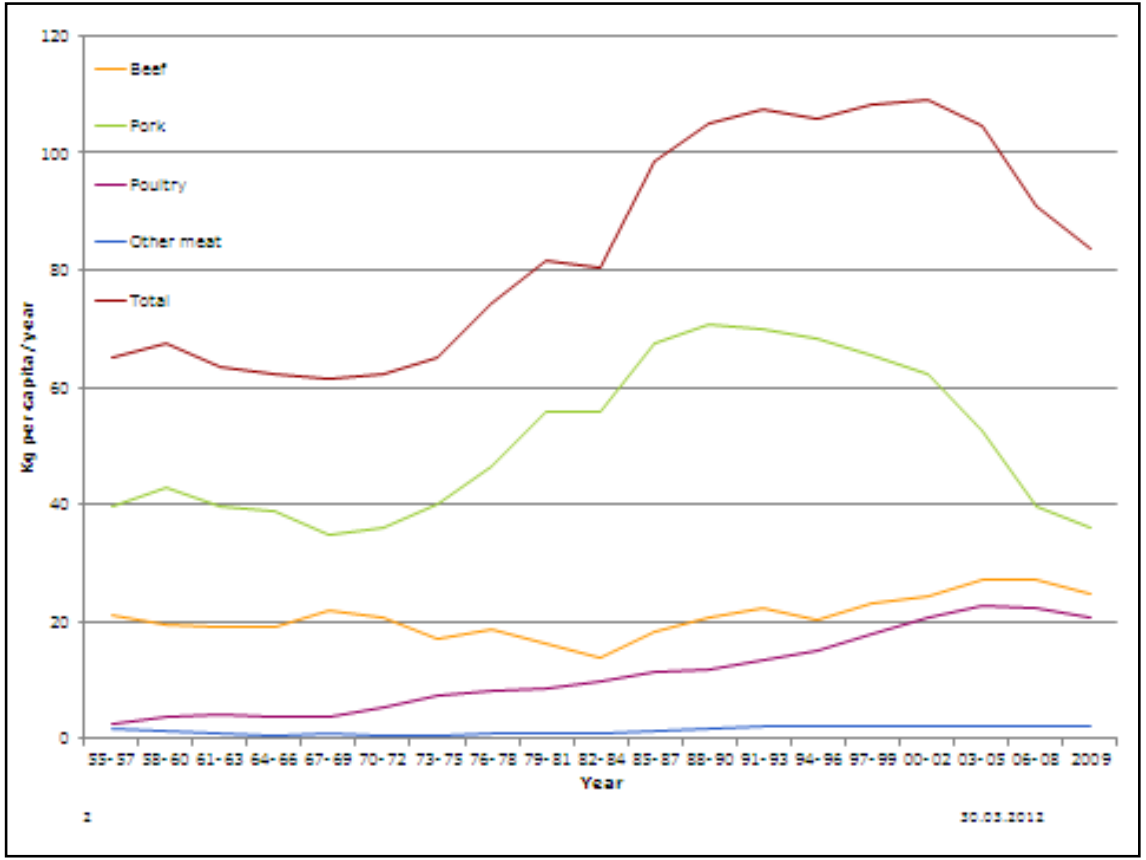

Beef (yellow), pork (green), poultry (pink), other meat (blue) and total meat (red) in Denmark (Fagt et al., unpublished results). 


\subsubsection{Finland}

According to the previous Findiet studies (Anttolainen et al., 1998; Männistö et al., 2003; Paturi et al., 2008; Kleemola et al., 1992) the supply of meat has been relatively constant over the past 20 years. When comparing supply of different types of meat, it appears that the supply of red meat and processed meat has decreased slightly over time and that the intake of poultry has increased in the same period. However, according to the supply statistics of Ministry of Agriculture and Forestry the per capita supply of pork and poultry has increased during the past four decades from 21 to 35 and 1 to $18 \mathrm{~kg}$ per capita per year. Supply of beef has decreased slightly (Figure 2).

\section{Figure 2. Per capita supply (kg/capita/y)}

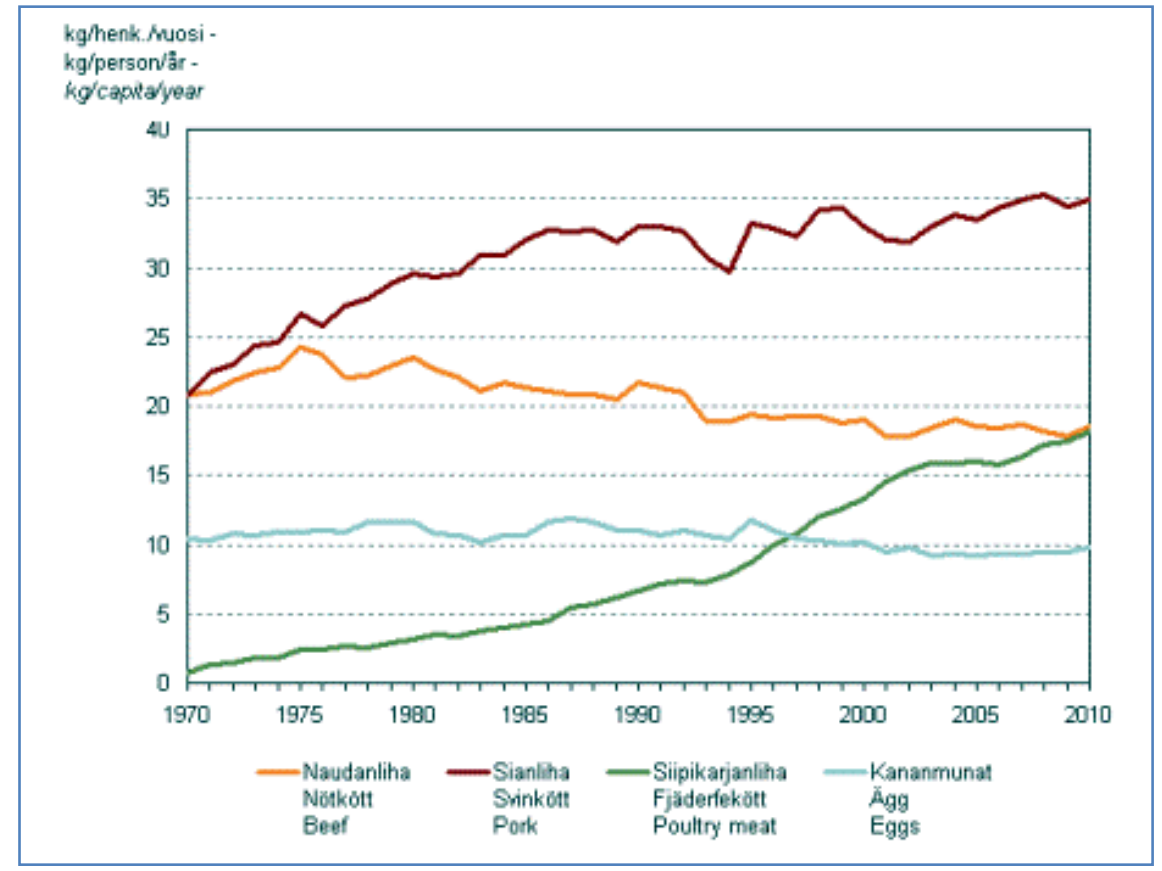

Beef (yellow), pork (red), poultry (green) and eggs (blue) in Finland (Information Centre of the Ministry of Agriculture and Forestry in Finland (Tike), 2012).

\subsubsection{Norway}

The supply of meat has increased considerably in Norway over a longer period of time, from $53 \mathrm{~kg}$ in 1989 to $77 \mathrm{~kg}$ per capita per year in 2008 (Helsedirektoratet, 2011). However, since 2010, the meat supply has decreased with almost $3 \mathrm{~kg}$ per capita per year (Figure 3 ). The supply of white meat (poultry) increased from 5 to $18 \mathrm{~kg}$ per capita per year in the 
period 1989-2009, but decreased somewhat in 2010. Supply of red meat (pork, cattle, sheep and goat) increased from 43 to $53 \mathrm{~kg}$ per capita per year in the period 1989 to 2008, but has since decreased to $50 \mathrm{~kg}$.

Figure 3. Per capita supply (kg/capita/y)

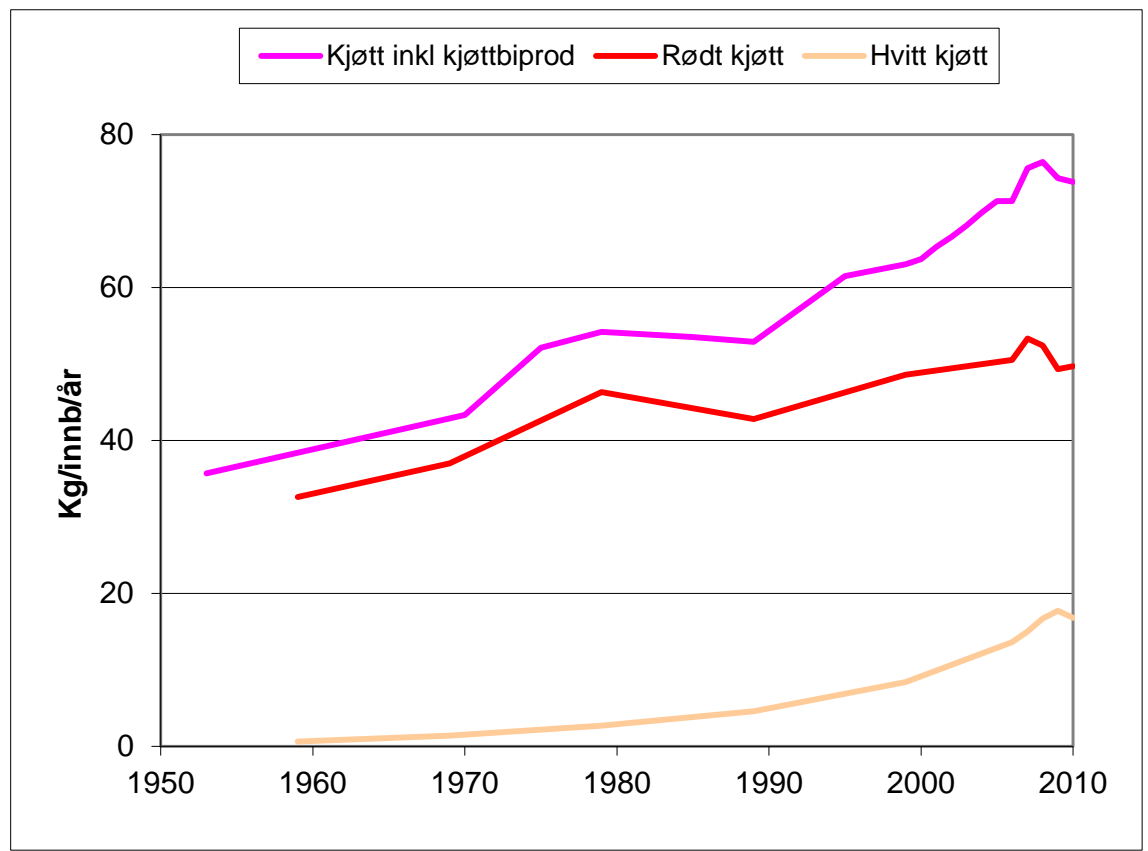

Meat, incl. meat products (pink), red meat (red), and white meat (yellow), in Norway (Helsedirektoratet, 2011).

\subsubsection{Sweden}

In Sweden the annual per capita total meat supply has increased from 51 $\mathrm{kg}$ in 1950 to about $85 \mathrm{~kg}$ in 2010 (Statens Jordbruksverk, 2012). Supply of red meat increased from $59 \mathrm{~kg}$ in 1980 to $67 \mathrm{~kg}$ in 2010, while the supply of white meat increased from approximately $5 \mathrm{~kg}$ to $18 \mathrm{~kg}$ in the same period (Figure 4). 
Figure 4. Per capita supply (kg/capita/y)

4. Totalkonsumtion av kött, kg per person och år

4. Total consumption of meat, $\mathrm{kg}$ per capita and year

$\mathrm{Kg}$

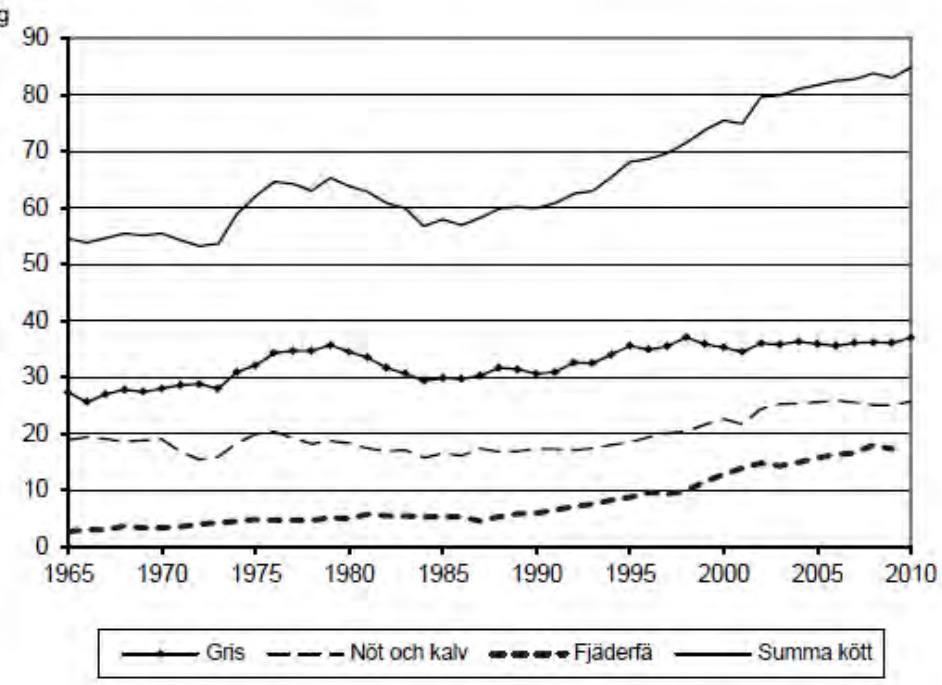

Total meat (full line), pig (dotted line), cattle and veil (thin dashed line), and poultry (thick dashed line), in Sweden (Statens Jordbruksverk, 2012). 


\section{Materials and Methods}

The nutritional consequences of the WCRF recommendations was evaluated in the light of the diet in selected Nordic countries. Representative data on dietary intake and dietary patterns in the four participating Nordic countries, Denmark, Finland, Norway and Sweden, were used to estimate nutrient intakes in different age and sex groups at varying meat intakes and especially the categorization of meat was evaluated. Actual and recent meat intakes from the four participating countries were modulated to various predetermined levels, including the recommended level suggested by the WCRF and the nutritional consequences for adults, children and adolescents were assessed using the present nutritional recommendations (Nordic Council of Ministers, 2004) as the recommended level of nutrient intake.

It is expected that the present report can be used as a basis for setting future specific meat and meat product guidelines. It is expected that the results of the analyses will reflect the particular dietary patterns and cultures in the different Nordic countries.

\subsection{Description of estimation of meat intake in the participating countries}

\subsubsection{Dietary data used in this project}

Dietary data used in this project originate from four different countries. (Table 3) provides an overview of the methods used to collect dietary data, the period in which the dietary data were collected as well as the age groups, number of participants and food composition tables used. 


\begin{tabular}{|c|c|c|c|c|c|c|}
\hline Country & Dietary study & Method & Period & Age groups & $\mathbf{N}$ & $\begin{array}{l}\text { Food composi- } \\
\text { tion table }\end{array}$ \\
\hline DK & $\begin{array}{l}\text { Danish National Survey } \\
\text { of Diet and Physical } \\
\text { Activity, DANSDA }\end{array}$ & $7 \mathrm{~d}$ dietary record & $2005-2008$ & $\begin{array}{l}4-9 y \\
10-17 y \\
18-75 y\end{array}$ & $\begin{array}{r}298 \\
377 \\
2025\end{array}$ & $\begin{array}{l}\text { Foodcomp.dk, } \\
\text { release } 7.0\end{array}$ \\
\hline $\mathrm{Fl}-1$ & FINDIET 2007 & $48 \mathrm{~h}$ recall & 2007 & $25-74$ & 2039 & $\begin{array}{l}\text { Fineli Nutrition } \\
\text { Database, } \\
\text { release } 7\end{array}$ \\
\hline $\mathrm{Fl}-2$ & $\begin{array}{l}\text { Dietary habits and well- } \\
\text { being of secondary } \\
\text { school pupils (DHWS) }\end{array}$ & $48 \mathrm{~h}$ recall & $2007-2008$ & $\begin{array}{l}7^{\text {th }} \text { graders (13- } \\
14 \mathrm{y})\end{array}$ & 306 & $\begin{array}{l}\text { Fineli Nutrition } \\
\text { Database, } \\
\text { release } 8\end{array}$ \\
\hline NO -1 & Norkost & $\begin{array}{l}2 * 24 \mathrm{~h} \text { recall and } \\
\text { Food propensity } \\
\text { questionnaire }\end{array}$ & 2010-2011 & $18-70 y$ & 1787 & $\begin{array}{l}\text { Norkost (based } \\
\text { on the Norwe- } \\
\text { gian Food } \\
\text { composition } \\
\text { table-2006) }\end{array}$ \\
\hline $\mathrm{NO}-2$ & Ungkost 2000 & $4 \mathrm{~d}$ dietary record & $\begin{array}{l}2000 \\
2001 \\
2001\end{array}$ & $\begin{array}{l}4 y \\
8-10 y \\
12-14 y\end{array}$ & $\begin{array}{r}394 \\
815 \\
1009\end{array}$ & $\begin{array}{l}\text { Instiutt for } \\
\text { Ernærings- } \\
\text { forskning } 1996 \\
\text { (based on the } \\
\text { Norwegian Food } \\
\text { composition } \\
\text { table-1995) }\end{array}$ \\
\hline SE -1 & $\begin{array}{l}\text { The Swedish National } \\
\text { Dietary Survey - Riks- } \\
\text { maten children } 2003\end{array}$ & $\begin{array}{l}\text { Open estimated } \\
\text { food diary over } 4 \\
\text { consecutive days }\end{array}$ & 2003 & $\begin{array}{l}4 \text { y School } \\
\text { children in: } \\
\text { grade } 2 \text { grade } 5\end{array}$ & $\begin{array}{r}590(4 y) \\
889(\text { gr } 2) \\
1016(\text { gr5) }\end{array}$ & $\begin{array}{l}\text { Livsmedelsda- } \\
\text { tabasen, ver. } \\
\text { Riksmaten } \\
\text { children } 2003\end{array}$ \\
\hline SE -2 & $\begin{array}{l}\text { The Swedish National } \\
\text { Dietary Survey - Riks- } \\
\text { maten adults 2010-11 }\end{array}$ & $\begin{array}{l}\text { Web-based } \\
\text { dietary record for } \\
4 \text { consecutive } \\
\text { days }\end{array}$ & 2010-2011 & $18-80 y$ & 1797 & $\begin{array}{l}\text { Livsmedelsda- } \\
\text { tabasen, } \\
\text { release Riks- } \\
\text { maten adults } \\
2010\end{array}$ \\
\hline
\end{tabular}

\subsubsection{Participation rate and representativity}

\section{Denmark}

Participation rate in the Danish National Survey of Dietary habits and Physical Activity (DANSDA) 2003-2008 was 53\%; $50.2 \%$ for adults (15-75 years of age) and $69.8 \%$ for children (4-14 years of age). Participants were recruited through the Central Office of Civil Registration, using a random sample covering nationwide.

\section{Finland}

Participation rate in Findiet 2007 was 63\% (Paturi et al., 2008). Findiet is a part of a health survey called FINRISK which monitors risk factors of chronic diseases regularly every 5 years. In the FINRISK study the representative sample was a random sample from the Finnish Population 
Information System, stratified according to sex, 10-year age groups, and the five geographical areas (Männistö et al., 2012). Although the study does not cover the whole of Finland, it is assumed that the situation in non-studied areas does not critically differ from the areas being studied. One third of the people invited to participate in the FINRISK study was also invited to the Findiet 2007 study. It was tested statistically (t-test) that the age, weight and daily amount of smoking occations were parallel with the rest of the FINRISK participants (Paturi et al., 2008).

Participation rate for adolescents in the Dietary Habits and Wellbeing of Secondary School Pupils survey was 52\% (Hoppu et al., 2008; Hoppu et al., 2010). Participants were from 12 secondary schools including 77 classes located in three different cities. Initially 23 schools were asked to join the study, and 12 of these schools entered the study with the permission of the principal. It is possible that in this phase there were more active schools and schools that were more favourable towards development selected to the study. Although one common reason for declining to participate was participation already in other studies. Some schools did not justify their decision to be left out with any reason.

Random sampling was not used, but the study probably still describes quite well the situation with the young nowadays in Finland because there were different sizes of cities and diverse schools included. There were several differences between the schools already at baseline. City schools might have been different from suburban schools because of the family backgrounds of the pupils. Also the emphasis on special education such as music, languages or sports could affect the students to be diverse in different schools.

\section{Norway}

In Norkost the invited sample was representative of the Norwegian population aged 18-70 y. The adult participation rate was 37\%. In Ungkost a representative sample of schools were invited to participate. The participation rate for the 9 -y-olds was $81 \%$, and for the 13 -y-olds $86 \%$.

\section{Sweden}

In the Riksmaten Adults survey, the invited sample for the adults was representative of the Swedish population and stratified on sex, age group (18-30 years, 30-44 years, 45-64 years and 65-80 years) and region. The participation rate was $36 \%$.

In the Riksmaten Children survey, children that turned 4 years in 2003 and those who attended grade 2 or 5 during 2003 were invited to participate. When the sample was drawn income and educational level of the family plus region were taken into account to get a representative sample 
in each age category. The participation rate was $64 \%$ among the 4 year olds, among the two- graders $74 \%$ and among the five-graders $79 \%$.

\subsubsection{Under-and over-reporting}

\section{Denmark}

In the Danish National Surveys of Dietary Habits and Physical Activity under-reporting was estimated according to the Goldberg method (Goldberg et al., 1991) and expressed as the percentages having a ratio between energy intake and basal metabolic rate (EI/BMR) below 1.1 was in 2003-2006 26\% among adults (15-75 years of age) and $16 \%$ among children (4-14 years of age).

\section{Finland}

In the Findiet report under-reporters were calculated as those subjects with an energy intake below their calculated basal metabolic rate (men 34\%, women $41 \%$ ). In this report only the nutrient intake distributions were done so that the under-reporters were excluded, but the results were shown also without the exclusion of under-reporters. (Paturi et al., 2008). The exclusion of under-reporters from data had only a minor impact on the results. Analyses for this report therefore included the under-reporters. In a Findiet related study it was noticed that under-reporting was evenly distributed between different food items, which means that the ratio between energy nutrients remained correct (Hirvonen et al., 1997).

The study on secondary school pupils included an intervention and the $48 \mathrm{~h}$ recall was repeated in 2008 . The energy intake did not change when comparing results from years 2007 and 2008. This could reflect the increasing under-reporting with aging because these are growing children and thus it could have been assumed that the energy intake would have increased. On the other hand it also indicates that underreporting has probably happened to a lesser extent - but was not taken into consideration for the present report.

\section{Norway}

In Norkost, under- and over-reporting has been assessed on the basis of values from (Black, 2000a; Black, 2000b), that participants who had a EI/BMR under 0.96 were very likely to under-report energy intake, and that those with EI/BMR $>2.49$ were very likely to over-report energy intake. It was found that $16 \%$ under-reported energy intake, and $1.5 \%$ over-reported energy intake. The difference between the proportion of women $(17 \%)$ and men $(15 \%)$ who were under-reporting was small. 


\section{Sweden}

In Riksmaten 2010-11 the degree of under- and over-reporting was calculated according to Black (Black, 2000b). There was a probability of under-reporting when EI/BMR $<0.93$ and of over-reporting when EI/BMR $>3.01$. Based on these cut-offs under-reporting was $16 \%$ in women and $21 \%$ in men. Over-reporting was very rare. In Riksmaten children 2003 the degree of under-reporting was evaluated with the Goldberg cut off $(\mathrm{EI} / \mathrm{BMR}<1.06)$ and was $2 \%$ in the 4 year olds, $6 \%$ in the $2^{\text {nd }}$ graders and $25 \%$ in the $5^{\text {th }}$ graders.

\subsubsection{Description of meat intake}

A description of the meat intake in the four different countries is provided in Table 4.

\begin{tabular}{|c|c|c|c|}
\hline Country & Meat and meat groups by origin & Processed meat & Processing methods \\
\hline DK & $\begin{array}{l}\text { Meat: beef, veal, pork, lamb, no } \\
\text { venison. } \\
\text { Poultry: chicken, turkey, duck, } \\
\text { goose } \\
\text { Offal: liver }\end{array}$ & $\begin{array}{l}\text { Cold cuts, sausages, ham, } \\
\text { bacon, salami-type sausages, } \\
\text { blood- and liver-containing } \\
\text { pates and sausages }\end{array}$ & $\begin{array}{l}\text { Can be estimated from } \\
\text { household purchases } \\
\text { surveys into: smoked, } \\
\text { salted, other conservatives } \\
\text { and others }\end{array}$ \\
\hline $\mathrm{FI}$ & $\begin{array}{l}\text { Meat: beef, pork, mutton, game. } \\
\text { Poultry: chicken, turkey. } \\
\text { Offal: liver }\end{array}$ & Cold cuts, sausages & $\begin{array}{l}\text { Can be estimated from the } \\
\text { name of the product but it } \\
\text { has not been documented } \\
\text { in the database }\end{array}$ \\
\hline NO-1 & $\begin{array}{l}\text { Open questions ( } 24 \mathrm{~h} \text { recall); all } \\
\text { types of meat are possibly report- } \\
\text { ed. } \\
\text { KBS (KostBeregningsSystem) } \\
\text { contains a wide range of different } \\
\text { types of meats, and the database } \\
\text { is continually updated }\end{array}$ & $\begin{array}{l}\text { Open questions ( } 24 \mathrm{~h} \text { recall); all } \\
\text { types of processed meat are } \\
\text { possibly reported. } \\
\text { KBS (KostBeregningsSystem) } \\
\text { contains a wide range of differ- } \\
\text { ent types of meats, and the } \\
\text { database is continually updated }\end{array}$ & $\begin{array}{l}\text { Can be estimated, but are } \\
\text { not described in reports }\end{array}$ \\
\hline NO-2 & $\begin{array}{l}\text { Meat: beef, lamb, pork, moose, } \\
\text { reindeer } \\
\text { Poultry: chicken } \\
\text { Offal: liver }\end{array}$ & $\begin{array}{l}\text { Sausages, ham, bacon, liver } \\
\text { paste, salami }\end{array}$ & $\begin{array}{l}\text { No information about } \\
\text { processing methods }\end{array}$ \\
\hline SE -1 & $\begin{array}{l}\text { Meat: beef, veal, pork, lamb, } \\
\text { moose, reindeer, horse } \\
\text { Poultry: chicken, turkey, goose } \\
\text { Offal: liver }\end{array}$ & $\begin{array}{l}\text { Cold cuts; sausages; ham and } \\
\text { bacon; salami-type sausages; } \\
\text { blood- and liver-containing } \\
\text { pates and sausages }\end{array}$ & $\begin{array}{l}\text { Salted, smoked or cured to } \\
\text { prolong self-life }\end{array}$ \\
\hline SE-2 & $\begin{array}{l}\text { Meat: beef, veal, pork, lamb, } \\
\text { moose, reindeer, horse, deer, roe } \\
\text { deer, wild boar, hare, rabbit. } \\
\text { Poultry: chicken, turkey, ostrich, } \\
\text { goose, duck, grouse, pheasant, } \\
\text { pigeon. } \\
\text { Offal: Liver, kidney, tongue, heart, } \\
\text { thymus }\end{array}$ & $\begin{array}{l}\text { Cold cuts; sausages; ham and } \\
\text { bacon; salami-type sausages; } \\
\text { blood- and liver-containing } \\
\text { pates and sausages }\end{array}$ & $\begin{array}{l}\text { Salted, smoked or cured to } \\
\text { prolong self-life }\end{array}$ \\
\hline
\end{tabular}




\subsubsection{Short description of data processing from meat to nutrient intakes}

In the present report, the amount of meat is reported in amount eaten. The calculation procedure from raw to consumed weight is described below for the different countries.

\section{Denmark}

The amount of meat (in grams) that is reported differs according to the type of meat. Meat reported in raw weight includes meat (pork, beef, lamb etc.), poultry, minced meat, and liver and the amount of meat eaten is calculated with $20 \%$ weight loss from raw meat to amount as eaten. Reported in product weight (as eaten) are processed meat like sausages, cold cuts, slices of ham etc. and liver paste.

Intake of vitamins and minerals is presented without estimated losses.

\section{Finland}

The final amount of meat (in grams) that is reported differs regarding the type of the meat. Meat reported in raw weight includes meat (pork, beef, lamb etc.), poultry and minced meat, and the amount of meat eaten is calculated with $20 \%$ weight loss from raw meat to amount as eaten. Reported in product weight are processed meat like sausages, cold cuts and slices of ham etc.

In this report nutrient losses have been taken into account for vitamin $A$, vitamin $C$, vitamin $B_{12}$, thiamine, niacin, folic acid, riboflavin and pyridoxine only for processed meat products (Bergström, 1994). Because other food products are analysed as raw products no nutrient losses are taken into account.

\section{Norway}

The final amount of meat (in grams) that is reported differs regarding of type of meat. Estimated in raw weight from the Norwegian diet calculation system is meat (pork, beef, lamb etc.), poultry, minced meat. Then raw meat weight is calculated with $20 \%$ weight loss to give amount as eaten, which is presented in the present report. Reported in product weight from the diet calculation system is processed meat like sausages, meatballs, slices of ham etc., liver paste, and ready meals.

Intake of vitamins and minerals is presented without estimated losses from raw weight.

Nutrient supplements were not included in the calculations. 


\section{Sweden}

The final amount of meat (in grams) is reported in amount as eaten.

Retention factors used in the Swedish database takes into consideration cooking method, food group and vitamin. The following vitamins are recalculated: vitamin $C$, thiamine, riboflavin, vitamin $B_{6}$, Folate and Vitamin $B_{12}$ (National Food Agency, 2012).

\subsection{Manual for the modelling exercise}

\subsubsection{Scenarios}

This manual contains a definition of meat and a specification of the recommendations of the World Cancer Research Fund to be used in the modelling of the current habitual meat intake in Denmark, Finland, Norway and Sweden to fulfil the WCRF in selected age groups when following the different scenarios (1-5) described below.

\section{Definition of meat (used in the current project):}

- Meat: all animal flesh from mammals and birds.

- Red meat: beef, pork, lamb and goat from domesticated animals and that contained in processed foods

- White meat: poultry

- Processed meat: meat preserved by smoking, curing or salting, or addition of chemical preservatives, including that contained in processed foods.

- Note: Fish is separate and wild game is not defined. 


\section{The World Cancer Research Fund recommendation (2007):}

- The personal recommendation to individuals consuming meat is to consume less that $500 \mathrm{~g}$ red meat a week $(70 \mathrm{~g} / \mathrm{d})$ with very little if any to be processed meat.

- The specific public health goal was an average consumption of red meat to be no more than $300 \mathrm{~g}$ of red meat per week $(43 \mathrm{~g} / \mathrm{d})$ and very little - if any processed meat.

The amounts are weight of meat as eaten.

Scenario $1 \quad$ Average habitual diet.

Scenario 2 Average habitual diet where the habitual red meat intake is reduced to $70 \mathrm{~g} / \mathrm{d}$ and the intake of processed meat intake is 0 $\mathrm{g} / \mathrm{d}$. The meat is substituted with $\mathrm{X} \mathrm{g}$ white meat/fish.

Scenario 3 Average habitual diet where the habitual red meat intake is reduced to $70 \mathrm{~g} / \mathrm{d}$ and the intake of processed meat intake is 0 $\mathrm{g} / \mathrm{d}$. The meat is substituted with a proportional amount of other food products but meat.

Scenario 4 Average habitual diet where the habitual red meat intake is reduced to $43 \mathrm{~g} / \mathrm{d}$ and the intake of processed meat intake is $0 \mathrm{~g} / \mathrm{d}$. The meat is substituted with $\mathrm{Xg}$ white meat/fish.

Scenario 5 Average habitual diet where the habitual red meat intake is reduced to $43 \mathrm{~g} / \mathrm{d}$ and the intake of processed meat intake is $0 \mathrm{~g} / \mathrm{d}$. The meat is substituted with a proportional amount of other food products but meat.

\section{Scenario 1}

Average habitual diet

\section{Step 1.1}

The habitual diet is segregated into the main food groups and age groups. The segregation of the total habitual diet into food groups may deviate slightly between countries. The important point is that the total meat intake can be segregated into "Red meat", "White meat" and "Processed meat". 


\section{Step 1.2}

The habitual dietary intakes at food group level are reported for adult women (18-75 y) and men (18-75 y), children (4-9 y) and adolescents $(10-17 \mathrm{y})$.

\section{Step 1.3}

The macronutrient distribution and the micronutrient intake are reported for the selected age groups.

\section{Scenario 2}

Average habitual diet where the habitual red meat intake is reduced to $70 \mathrm{~g} / \mathrm{d}$ and the intake of processed meat intake is $0 \mathrm{~g} / \mathrm{d}$. The meat is substituted with $\mathrm{Xg}$ white meat/fish.

\section{Step 2.1}

The red meat intake in the habitual diet is reduced to a total of $70 \mathrm{~g}$ red meat/d and the intake of processed meat is reduced to $0 \mathrm{~g} / \mathrm{d}$. The missing amount of meat (g) is substituted with $50 \%$ white meat (poultry) and $50 \%$ fish. The type of poultry and fish and its preparation is to be chosen in each country according to our knowledge of the habitual poultry/fish intake. The information should be included as a food-note to tables.

Step 2.2

Follow step 1.2

\section{Step 2.3}

Follow step 1.3

\section{Scenario 3}

Average habitual diet where the habitual red meat intake is reduced to $70 \mathrm{~g} / \mathrm{d}$ and the intake of processed meat intake is $0 \mathrm{~g} / \mathrm{d}$. The meat is substituted with a proportional amount of other food products but meat.

\section{Step 3.1}

The red meat intake in the habitual diet is reduced to a total of $70 \mathrm{~g}$ red meat/d and the intake of processed meat is reduced to $0 \mathrm{~g} / \mathrm{d}$. The missing amount of meat is substituted with a proportional amount of energy of non-meat products to obtain the average energy intake level as the habitual diet. The amount of non-meat should reflect the composition in the national habitual diet. 


\section{Step 3.2}

Follow step 1.2

\section{Step 3.3}

Follow step 1.3

\section{Scenario 4}

Average habitual diet where the habitual red meat intake is reduced to $43 \mathrm{~g} / \mathrm{d}$ and the intake of processed meat intake is $0 \mathrm{~g} / \mathrm{d}$. The meat is substituted with $\mathrm{X} g$ white meat/fish.

\section{Step 4.1}

The red meat intake in the habitual diet is reduced to a total of $43 \mathrm{~g}$ red meat/d and the intake of processed meat is reduced to $0 \mathrm{~g} / \mathrm{d}$. The missing amount of meat $(\mathrm{g})$ is substituted with $50 \%$ white meat (poultry) and $50 \%$ fish. The type of poultry and fish and its preparation is to be chosen in each country according to our knowledge of the habitual poultry/fish intake. The information should be included as a food-note to tables.

\section{Step 4.2}

Follow step 1.2

\section{Step 4.3}

Follow step 1.3

\section{Scenario 5}

Average habitual diet where the habitual red meat intake is reduced to $43 \mathrm{~g} / \mathrm{d}$ and the intake of processed meat intake is $0 \mathrm{~g} / \mathrm{d}$. The meat is substituted with a proportional amount of other food products but meat.

\section{Step 5.1}

The red meat intake in the habitual diet is reduced to a total of $43 \mathrm{~g}$ red meat/d and the intake of processed meat is reduced to $0 \mathrm{~g} / \mathrm{d}$. The missing information amount of meat is substituted with a proportional amount of energy of non- meat products to obtain the average energy intake level as the habitual diet. The amount of non-meat should reflect the composition in the national habitual diet.

\section{Step 5.2}

Follow step 1.2 


\section{Step 5.3}

Follow step 1.3

\subsubsection{Calculation procedure}

\section{Denmark}

Calculations were done for children 4-9 years $(\mathrm{n}=298)$, children 10-17 years $(\mathrm{n}=377)$, men $18-75$ years $(\mathrm{n}=932)$, and women $18-75$ years $(\mathrm{n}=1093)$ from the 2005-2008 population in The Danish National Survey of Dietary Habits and Physical Activity. Dietary intakes were recorded for seven consecutive days in a pre-coded food record. The food composition table used was foodcomp.dk, ver. 7.0.

In our analyses, food intakes are divided into food groups and are reported in eaten/cooked amounts. Intakes of vitamins and minerals are calculated from raw food items. All intakes of vitamins and minerals were without contribution from supplements.

\section{Scenario 1}

Scenario 1 represents an average diet for each of the four groups. Dietary intake is reported at food group level, and the macro- and micronutrient distributions in an average diet are presented.

\section{Scenario 2}

In scenario 2 , the amount of red meat is reduced to 70 g per day (only men and older boys consume more than $70 \mathrm{~g}$ red meat) and processed meat is reduced to $0 \mathrm{~g}$ per day (all groups). The removed amount (g) is distributed to poultry and fish (50\% on each). The total amount of foods and drinks (g) is identical with that in Scenario 1, but the energy content differs.

\section{Scenario 3}

In scenario 3, the amount of red meat is reduced to $70 \mathrm{~g}$ per day (only men and older boys consume more than $70 \mathrm{~g}$ red meat) and processed meat is reduced to $0 \mathrm{~g}$ per day (all groups). The removed energy from red meat and processed meat is distributed proportionally on all other food groups (incl. fish) in the average diet (scenario 1). The energy content in scenarios 1 and 3 are identical, but the amount (g) of foods and drinks differs. 


\section{Scenario 4}

In scenario 4 , the amount of red meat is reduced to $43 \mathrm{~g}$ per day (young children consume less than $43 \mathrm{~g}$ of red meat, making scenarios 4 and 5 identical to scenarios 2 and 3, respectively, and therefore irrelevant for this group) and processed meat is reduced to $0 \mathrm{~g}$ per day (all groups). The removed amount $(\mathrm{g})$ is distributed to poultry and fish $(50 \%$ on each). The total amount of foods and drinks (g) is identical with that in Scenario 1 and 2, but the energy content differs.

\section{Scenario 5}

In scenario 4, the amount of red meat is reduced to $43 \mathrm{~g}$ per day (young children consume less than $43 \mathrm{~g}$ of red meat, making scenarios 4 and 5 identical to scenarios 2 and 3, respectively, and therefore irrelevant for this group) and processed meat is reduced to $0 \mathrm{~g}$ per day (all groups). The removed energy from red meat and processed meat is distributed proportionally on all other food groups (incl. fish) in the average diet (scenario 1). The energy content in scenarios 1, 3 and 5 are identical, but the amount $(\mathrm{g})$ of foods and drinks differs.

\section{Finland}

Calculations were done for men $(\mathrm{n}=958)$ and women $(\mathrm{n}=1080)$ aged 2574 and for boys $(n=136)$ and girls $(n=170)$ aged 13 to 14 . Both datasets are based on $48 \mathrm{~h}$ recall.

In Finnish studies and analyses the eaten foods are split in to food items as they are in recipes and they are divided into the named food groups. These food items are thus counted as raw material (raw meat, raw vegetables etc.) and nutrient losses due to cooking processes are not taken into account.

Calculations were started with counting the average intake of different food groups in an average diet per grams and the average intake of specific nutrients from the whole diet. Also the average intakes of studied nutrients from each food groups were calculated for each gender and age groups. This information was used in calculations of scenarios 2-5. The food composition table used was Fineli Nutrition Database, release 7 and 8. All intakes of vitamins and minerals were without contribution from supplements. 


\section{Scenario 1}

This is the "habitual" situation of Finnish adult diet. Dietary intake is reported at food group level and also the macro- and micronutrient distributions in an average diet are presented.

\section{Scenario 2}

In scenario 2 the amount of processed meat is reduced to $0 \mathrm{~g}$ per day and the removed amount $(\mathrm{g})$ is distributed to poultry and fish $(50 \%$ on each). The intake of red meat does not exceed $70 \mathrm{~g} / \mathrm{d}$ in any of the population groups and that is why only processed meat is substituted.

\section{Scenario 3}

In scenario 3 the amount of processed meat is reduced to $0 \mathrm{~g}$ per day and the removed amount is substituted with most common non-meat food items so that the energy intake does not change. Non-meat products are chosen according to what is used the most as grams (potato, rice and pasta group, bread and cereals group, milk products and vegetables). The amounts of added non-meat products are balanced so that the ratio of energy intake gained from each group does not change. The intake of red meat does not exceed $70 \mathrm{~g} / \mathrm{d}$ in any of the population groups and that is why only processed meat is substituted.

\section{Scenario 4}

In scenario 4 the amount of processed meat is reduced to $0 \mathrm{~g}$ per day and the intake of red meat to $43 \mathrm{~g} / \mathrm{d}$, if relevant (only adolescents and men consume more than $43 \mathrm{~g}$ red meat per day). The removed amount of red meat and processed meat is substituted with white meat and fish ( $50 \%$ on each) so that the total gram does not change.

\section{Scenario 5}

In scenario 5 the amount of processed meat is also reduced to $0 \mathrm{~g}$ per day and the amount of red meat is reduced to $43 \mathrm{~g} / \mathrm{d}$, if relevant (only adolescents and men consume more than $43 \mathrm{~g}$ red meat per day). The amount of reduced red meat products is substituted with non-meat products so that the energy intake does not change. Non-meat products are chosen according to what is used the most as grams (potato, rice and pasta group, bread and cereals group, milk products and vegetables). The amount of added non-meat products are balanced so that the ratio of energy intake gained from each group is the same as in the beginning. 


\section{Norway}

Calculations were done for men $(n=862)$ and women $(n=925)$ aged 1870 years and children aged $9(\mathrm{n}=810)$ and $13(\mathrm{n}=1005)$ years. Data on adults were based on two independent 24 hour dietary recalls (Norkost $3,2010-2011$ ), and data on children were collected using pre-coded food diaries during 4 consecutive days (Ungkost, 2000).

In our studies and analyses the eaten foods are split into food items as they are in recipes and they are divided into the named food groups. All foods items are thus calculated as raw weight originally. For the purpose of these analysis the food groups of red meat (see description of food group below) and white meat (see description of food group below) was calculated into cooked/prepared weight (ready to eat) by removing $20 \%$ of the original weight. No recalculations to prepared/ready to eat weight were estimated for the food group of processed meat (see description of food group below) because most of the foods included in this group were already in ready to eat weight. No recalculations to prepared/ready to eat weight were estimated for any other foods than meat. All micronutrients were kept as in the original foods, no losses are estimated.

Red meat includes meat from mammal animals including game and whale meat. Minced meat from these animals and products made from minced meat are also included. White meat includes meat from all birds including duck and chicken, but excluding game. Minced meat from these and products made from minced meat are also included. Processed meat includes salted, preserved and canned red and white meat, including sausages, ham, liver paste and other products of blood and innards.

Calculations were started with counting the average intake of macroand macronutrients from the different food groups in grams per day. The food composition table used was Norkost3. All intakes of vitamins and minerals were without contribution from supplements.

\section{Sweden}

Calculations were done with data from the two latest Swedish national dietary surveys (Riksmaten) from 2003 in children and 2010-11 in adults. We analysed data from children aged 4 and from grade 2 (age 8) and grade 5 (age 11), in total 1232 girls and 1263 boys. In the adults calculations were done in women (18-75 years, $\mathrm{n}=982)$ and men $(18-75$ years, $\mathrm{n}=762$ ). The national survey in adults included individuals aged 18-80 years but for the present analyses those between 76 and 80 years of age were excluded $(n=53)$. 
For adults, dietary intakes were recorded in an internet-based dietary record for four consecutive days. The internet application contains 1900 food items and dishes. A printed portion guide, household measures, numbers and grams were used to estimate the amounts eaten. The application (version 04.1) is linked to the food composition database (Livsmedelsdatabasen, version Riksmaten adults 2010-11) held at the National Food Agency. All food items and dishes are linked to one main food group (dishes are intact) and to one or more composite food groups (dishes are broken into ingredients).

In the children, dietary intakes were recorded in an open written food diary for four consecutive days. A printed portion guide, household measures, numbers and grams were used to estimate the amounts eaten and main food groups were available in the survey in children.

All intakes of vitamins and minerals were without contribution from supplements.

\section{Scenario 1}

Scenario 1 represents an average diet of the Swedish population in men, women and children. Dietary intake is reported at food group level, and the macro- and micronutrient distributions of the average diet are presented.

\section{Scenario 2}

In scenario 2 , the amount of red meat is reduced to $70 \mathrm{~g}$ per day, except in women who consumed less than $70 \mathrm{~g}$ red meat, and processed meat is reduced to $0 \mathrm{~g}$ per day (all groups). The removed meat amount ( $\mathrm{g}$ ) is replaced with the same amount of poultry and fish (50\% on each). The total amount of foods and drinks (g) is identical with that in Scenario 1, but the energy content differs.

\section{Scenario 3}

In scenario 3, the amount of red meat is reduced to $70 \mathrm{~g}$ per day, except in women who consumed less than $70 \mathrm{~g}$ red meat, and processed meat is reduced to $0 \mathrm{~g}$ per day (all groups). The removed energy from red meat and processed meat is distributed proportionally on all other food groups (incl. fish) in the average diet (scenario 1). The energy content in scenario 1 and 3 are identical, but the amount (g) of foods and drinks differs. 


\section{Scenario 4}

In scenario 4 , the amount of red meat is reduced to $43 \mathrm{~g}$ per day and processed meat is reduced to $0 \mathrm{~g}$ per day (all groups). The removed meat amount $(\mathrm{g})$ is replaced with the same amount of poultry and fish $(50 \%$ on each). The total amount of foods and drinks (g) is identical with that in Scenario 1 and 2, but the energy content differs.

\section{Scenario 5}

In scenario 4 , the amount of red meat is reduced to $43 \mathrm{~g}$ per day and processed meat is reduced to $0 \mathrm{~g}$ per day (all groups). The removed energy from red meat and processed meat is distributed proportionally on all other food groups (incl. fish) in the average diet (scenario 1). The energy content in scenarios 1, 3 and 5 are identical, but the amount (g) of foods and drinks differs. 


\section{Results}

Results for the five scenarios, for women, men, children and adolescents from each of the four countries are provided in the appendix (Table A1-A45).

\subsection{Women}

The habitual intake of meat and fish in Danish, Finnish, Norwegian and Swedish women can be seen in (Table 5). The figures for women are similar across the four countries with the lowest intake of fish in Denmark, and the highest intake of meat in Norway.

Table 5. Habitual diet of women, Scenario 1. Intake of meat and fish (avg. g/d)

\begin{tabular}{lrrrr}
\hline & $\begin{array}{r}\text { Denmark 18-75y } \\
(\mathbf{n = 1 0 9 3 )}\end{array}$ & $\begin{array}{r}\text { Finland 25-74y } \\
(\mathbf{n = 1 0 8 0})\end{array}$ & $\begin{array}{r}\text { Norway 18-70y } \\
\text { (n=925) }\end{array}$ & $\begin{array}{r}\text { Sweden 18-75y } \\
\text { (n=982) }\end{array}$ \\
\hline Meat, total & 86 & 76 & 100 & 89 \\
Red meat & 47 & 30 & 44 & 45 \\
White meat & 15 & 18 & 20 & 20 \\
Processed meat & 24 & 27 & 36 & 23 \\
Fish & 16 & 23 & 56 & 43 \\
\hline
\end{tabular}

The distribution of macronutrients in the five scenarios for Danish, Finnish, Norwegian and Swedish women can be seen in Table 6. The macronutrient distribution for women is similar across the four countries with protein and carbohydrate intakes expressed as percentage of total energy intake within the recommended range, and fat energy percentage above 30 in the habitual diet. The distribution of macronutrients changes very little throughout the five scenarios. 
Table 6. Macronutrient distribution in women in Scenarios 1-5

\begin{tabular}{|c|c|c|c|c|c|}
\hline & $\begin{array}{l}\text { Denmark 18- } \\
75 y(n=1093)\end{array}$ & $\begin{array}{l}\text { Finland 25- } \\
74 y(n=1080)\end{array}$ & $\begin{array}{l}\text { Norway 18- } \\
70 y(n=925)\end{array}$ & $\begin{array}{l}\text { Sweden 18- } \\
75 y(n=982)\end{array}$ & NNR 2004 \\
\hline \multicolumn{6}{|l|}{ Scenario 1} \\
\hline Protein, E\% & 15.0 & 17.5 & 17.6 & 17.3 & $10-20$ \\
\hline Fat, E\% & 34.4 & 31.4 & 35.5 & 35.5 & 30 \\
\hline Carbohydrate, E\% & 50.7 & 51.1 & 46.9 & 47.2 & $50-60$ \\
\hline \multicolumn{6}{|l|}{ Scenario 2} \\
\hline Protein, E\% & 15.4 & 18.0 & 18.4 & 17.2 & $10-20$ \\
\hline Fat, E\% & 33.4 & 31.1 & 34.2 & 35.3 & 30 \\
\hline Carbohydrate, E\% & 51.2 & 51.0 & 47.3 & 47.2 & $50-60$ \\
\hline \multicolumn{6}{|l|}{ Scenario 3} \\
\hline Protein, E\% & 14.6 & 16.9 & 17.1 & 16.6 & $10-20$ \\
\hline Fat, E\% & 33.1 & 30.1 & 34.1 & 35.0 & 30 \\
\hline Carbohydrate, E\% & 52.3 & 53.1 & 48.8 & 48.3 & $50-60$ \\
\hline \multicolumn{6}{|l|}{ Scenario 4} \\
\hline Protein, E\% & 15.4 & 18.0 & 18.4 & 17.2 & $10-20$ \\
\hline Fat, E\% & 34.4 & 31.1 & 34.2 & 35.3 & 30 \\
\hline Carbohydrate, E\% & 51.2 & 51.0 & 47.4 & 47.2 & $50-60$ \\
\hline \multicolumn{6}{|l|}{ Scenario 5} \\
\hline Protein, E\% & 14.5 & 16.9 & 17.1 & 16.5 & $10-20$ \\
\hline Fat, E\% & 33.0 & 30.1 & 34.1 & 34.8 & 30 \\
\hline Carbohydrate, E\% & 52.6 & 53.1 & 48.8 & 48.3 & $50-60$ \\
\hline
\end{tabular}

Table 7 provides data on energy intake and contribution of saturated fat and intakes of selected micronutrients in women. The figures for women are similar across the four countries with very little changes throughout the five scenarios. Contributions from fat and saturated fat are higher than recommendations (Nordic Council of Ministers, 2004), but do not change markedly throughout the five scenarios. Intakes of vitamin D and iron are in general below recommendations (Nordic Council of Ministers, 2004), and do not change to any considerable degree with decreased intake of meat. 
Table 7. Energy and micronutrient intakes and contribution of fat and saturated fat in women in Scenarios 1-5

\begin{tabular}{|c|c|c|c|c|c|}
\hline & $\begin{array}{l}\text { Denmark 18- } \\
75 y(n=1093)\end{array}$ & $\begin{array}{r}\text { Finland 25- } \\
74 y(n=1080)\end{array}$ & $\begin{array}{l}\text { Norway 18- } \\
70 y(n=925)\end{array}$ & $\begin{array}{l}\text { Sweden 18- } \\
75 y(n=982)\end{array}$ & NNR 2004 \\
\hline \multicolumn{6}{|l|}{ Scenario 1} \\
\hline Energy, MJ & 7.9 & 6.6 & 8.0 & 7.4 & \\
\hline Saturated fat, E\% & 13.6 & 11.2 & 13.8 & 13.5 & $\leq 10$ \\
\hline Vitamin $B_{6}, \mathrm{mg}$ & 1.5 & 1.6 & 1.5 & 1.8 & 1.2 \\
\hline Vitamin $B_{12}, \mu \mathrm{g}$ & 4.5 & 4.7 & 6.0 & 5.0 & 2 \\
\hline Vitamin $D, \mu g$ & 3.0 & 5.5 & 4.9 & 6.4 & 7.5/10* \\
\hline Iron, mg & 9.0 & 10.2 & 9.9 & 9.5 & $15 / 9^{* *}$ \\
\hline \multicolumn{6}{|l|}{ Scenario 2} \\
\hline Energy, MJ & 7.8 & 6.6 & 7.9 & 7.4 & \\
\hline Saturated fat, E\% & 13.3 & 10.8 & 13.1 & 13.3 & $\leq 10$ \\
\hline Vitamin $B_{6}, \mathrm{mg}$ & 1.5 & 1.6 & 1.6 & 1.8 & 1.2 \\
\hline Vitamin $B_{12}, \mu \mathrm{g}$ & 4.6 & 5.4 & 6.2 & 5.3 & 2 \\
\hline Vitamin $D, \mu \mathrm{g}$ & 3.9 & 6.7 & 5.5 & 7.1 & $7.5 / 10^{*}$ \\
\hline Iron, mg & 8.7 & 10.2 & 9.4 & 9.4 & $15 / 9 * *$ \\
\hline \multicolumn{6}{|l|}{ Scenario 3} \\
\hline Energy, MJ & 7.9 & 6.6 & 8.0 & 7.4 & \\
\hline Saturated fat, E\% & 13.2 & 10.8 & 13.2 & 13.3 & $\leq 10$ \\
\hline Vitamin $\mathrm{B}_{6}, \mathrm{mg}$ & 1.5 & 1.5 & 1.5 & 1.9 & 1.2 \\
\hline Vitamin $B_{12}, \mu g$ & 4.0 & 4.6 & 5.5 & 5.1 & 2 \\
\hline Vitamin $D, \mu g$ & 2.9 & 5.5 & 5.1 & 6.5 & $7.5 / 10^{*}$ \\
\hline Iron, mg & 8.8 & 10.4 & 9.6 & 9.7 & $15 / 9 * *$ \\
\hline \multicolumn{6}{|l|}{ Scenario 4} \\
\hline Energy, MJ & 7.8 & 6.6 & 7.9 & 7.4 & \\
\hline Saturated fat, E\% & 13.2 & 10.8 & 13.1 & 13.3 & $\leq 10$ \\
\hline Vitamin $B_{6}, \mathrm{mg}$ & 1.5 & 1.6 & 1.6 & 1.8 & 1.2 \\
\hline Vitamin $B_{12}, \mu \mathrm{g}$ & 4.6 & 5.4 & 6.2 & 5.3 & 2 \\
\hline Vitamin $D, \mu g$ & 4.1 & 6.7 & 5.5 & 7.2 & $7.5 / 10^{*}$ \\
\hline Iron, mg & 8.7 & 10.2 & 9.3 & 9.4 & $15 / 9 * *$ \\
\hline \multicolumn{6}{|l|}{ Scenario 5} \\
\hline Energy, MJ & 7.9 & 6.6 & 8.0 & 7.4 & \\
\hline Saturated fat, E\% & 13.1 & 10.8 & 13.2 & 13.2 & $\leq 10$ \\
\hline Vitamin $B_{6}, \mathrm{mg}$ & 1.5 & 1.5 & 1.5 & 1.9 & 1.2 \\
\hline Vitamin $B_{12}, \mu g$ & 4.0 & 4.6 & 5.5 & 5.1 & 2 \\
\hline Vitamin $D, \mu g$ & 2.9 & 5.5 & 5.1 & 6.5 & $7.5 / 10^{*}$ \\
\hline Iron, mg & 8.8 & 10.4 & 9.6 & 9.7 & $15 / 9 * *$ \\
\hline
\end{tabular}

*age $\geq 61$ years, ** post menopause

\subsection{Men}

The habitual intake of meat and fish in Danish, Finnish, Norwegian and Swedish men can be seen in Table 8. The figures for men are similar across the four countries with the lowest intake of fish in Denmark, and the highest intake of meat in Norway. 
Table 8. Habitual diet of men, Scenario 1. Intake of meat and fish (avg. g/d)

\begin{tabular}{lrrrr}
\hline & $\begin{array}{r}\text { Denmark 18-75y } \\
(\mathbf{n}=\mathbf{9 3 2})\end{array}$ & $\begin{array}{r}\text { Finland 25-74y } \\
(\mathbf{n}=\mathbf{9 5 8})\end{array}$ & $\begin{array}{r}\text { Norway 18-70y } \\
(\mathbf{n}=\mathbf{8 6 2})\end{array}$ & $\begin{array}{r}\text { Sweden 18-75y } \\
\text { (n=762) }\end{array}$ \\
\hline Meat, total & 141 & 128 & 156 & 137 \\
Red meat & 74 & 48 & 72 & 74 \\
White meat & 19 & 23 & 26 & 23 \\
Processed meat & 49 & 57 & 58 & 40 \\
Fish & 20 & 28 & 79 & 51 \\
\hline
\end{tabular}

The distribution of macronutrients in the five scenarios for Danish, Finnish, Norwegian and Swedish men can be seen in Table 9. The macronutrient distribution for men is similar across the four countries with fat energy percentage above 30 and carbohydrate energy percentage below 50 in the habitual diet. The distribution of macronutrients changes very little throughout the five scenarios.

Table 9. Macronutrient distribution in men in Scenarios 1-5

\begin{tabular}{|c|c|c|c|c|c|}
\hline & $\begin{array}{r}\text { Denmark 18- } \\
75 y \\
(n=932)\end{array}$ & $\begin{array}{r}\begin{array}{r}\text { Finland 25- } \\
74 y \\
(n=958)\end{array} \\
\end{array}$ & $\begin{array}{r}\text { Norway } 18- \\
70 y \\
(n=862)\end{array}$ & $\begin{array}{r}\text { Sweden } 18- \\
75 y \\
(n=762)\end{array}$ & NNR 2004 \\
\hline \multicolumn{6}{|l|}{ Scenario 1} \\
\hline Protein, E\% & 15.2 & 17.4 & 17.9 & 17.8 & $10-20$ \\
\hline Fat, E\% & 36.6 & 33.6 & 35.5 & 35.3 & 30 \\
\hline Carbohydrate, E\% & 48.2 & 49.0 & 46.6 & 46.9 & $50-60$ \\
\hline \multicolumn{6}{|l|}{ Scenario 2} \\
\hline Protein, E\% & 15.8 & 18.4 & 18.9 & 17.8 & $10-20$ \\
\hline Fat, E\% & 35.0 & 32.8 & 33.8 & 35.0 & 30 \\
\hline Carbohydrate, E\% & 49.2 & 48.8 & 47.3 & 46.9 & $50-60$ \\
\hline \multicolumn{6}{|l|}{ Scenario 3} \\
\hline Protein, E\% & 14.5 & 16.6 & 17.3 & 16.9 & $10-20$ \\
\hline Fat, E\% & 34.4 & 31.0 & 33.5 & 34.3 & 30 \\
\hline Carbohydrate, E\% & 51.1 & 52.4 & 49.1 & 48.3 & $50-60$ \\
\hline \multicolumn{6}{|l|}{ Scenario 4} \\
\hline Protein, E\% & 15.8 & 18.4 & 19.0 & 17.7 & $10-20$ \\
\hline Fat, E\% & 34.8 & 32.7 & 33.4 & 34.7 & 30 \\
\hline Carbohydrate, E\% & 49.4 & 48.9 & 47.6 & 47.5 & $50-60$ \\
\hline \multicolumn{6}{|l|}{ Scenario 5} \\
\hline Protein, E\% & 13.9 & 16.5 & 17.3 & 16.3 & $10-20$ \\
\hline Fat, E\% & 33.8 & 30.8 & 33.5 & 33.6 & 30 \\
\hline Carbohydrate, E\% & 52.3 & 52.7 & 49.1 & 49.4 & $50-60$ \\
\hline
\end{tabular}

Table 10 provides data on energy intake and contribution of saturated fat and intakes of selected micronutrients in men. The figures for men are similar across the four countries with very little changes throughout the five scenarios. Contributions from fat and saturated fat are higher than recommendations (Nordic Council of Ministers, 2004), but do not change markedly throughout the five scenarios. Intake of vitamin D are below recommendations (Nordic Council of Ministers, 2004), in Danish men, and do not change to any considerable degree with decreased intake of meat. 
Table 10. Energy and micronutrient intakes and contribution of fat and saturated fat in men in Scenarios 1-5

\begin{tabular}{|c|c|c|c|c|c|}
\hline & $\begin{array}{r}\text { Denmark } 18-75 y \\
(n=932)\end{array}$ & $\begin{array}{r}\text { Finland } 25-74 y \\
(n=958)\end{array}$ & $\begin{array}{r}\text { Norway } 18-70 y \\
(n=862)\end{array}$ & $\begin{array}{r}\text { Sweden 18-75y } \\
(n=762)\end{array}$ & NNR 2004 \\
\hline \multicolumn{6}{|l|}{ Scenario 1} \\
\hline Energy, MJ & 10.4 & 8.9 & 10.9 & 9.4 & \\
\hline Saturated fat, E\% & 14.4 & 12.0 & 13.7 & 13.5 & $\leq 10$ \\
\hline Vitamin $\mathrm{B}_{6}, \mathrm{mg}$ & 1.9 & 2.1 & 1.9 & 2.3 & 1.6 \\
\hline Vitamin $B_{12}, \mu g$ & 6.5 & 6.6 & 8.9 & 6.0 & 2 \\
\hline Vitamin $D, \mu g$ & 3.8 & 7.5 & 6.7 & 7.6 & $7.5 / 10^{*}$ \\
\hline Iron, mg & 11.5 & 13.3 & 12.6 & 11.5 & 9 \\
\hline \multicolumn{6}{|l|}{ Scenario 2} \\
\hline Energy, MJ & 10.3 & 8.9 & 10.7 & 9.4 & \\
\hline Saturated fat, E\% & 13.9 & 11.3 & 12.9 & 13.2 & $\leq 10$ \\
\hline Vitamin $\mathrm{B}_{6}, \mathrm{mg}$ & 2.0 & 2.2 & 2.1 & 2.3 & 1.6 \\
\hline Vitamin $B_{12}, \mu g$ & 6.5 & 8.0 & 8.8 & 6.6 & 2 \\
\hline Vitamin $D, \mu g$ & 5.8 & 10.2 & 7.7 & 8.9 & $7.5 / 10^{*}$ \\
\hline Iron, mg & 10.8 & 13.4 & 11.8 & 11.3 & 9 \\
\hline \multicolumn{6}{|l|}{ Scenario 3} \\
\hline Energy, MJ & 10.4 & 8.9 & 10.9 & 9.4 & \\
\hline Saturated fat, E\% & 13.9 & 11.1 & 13.0 & 13.1 & $\leq 10$ \\
\hline Vitamin $B_{6}, \mathrm{mg}$ & 1.9 & 2.0 & 1.9 & 2.4 & 1.6 \\
\hline Vitamin $B_{12}, \mu g$ & 5.3 & 6.5 & 7.9 & 6.2 & 2 \\
\hline Vitamin $D, \mu g$ & 3.7 & 7.6 & 7.1 & 7.7 & $7.5 / 10^{*}$ \\
\hline Iron, mg & 10.9 & 13.7 & 12.1 & 11.7 & 9 \\
\hline \multicolumn{6}{|l|}{ Scenario 4} \\
\hline Energy, MJ & 10.3 & 8.9 & 10.6 & 9.3 & \\
\hline Saturated fat, E\% & 13.8 & 11.2 & 12.6 & 13.0 & $\leq 10$ \\
\hline Vitamin $\mathrm{B}_{6}, \mathrm{mg}$ & 2.0 & 2.2 & 2.2 & 2.3 & 1.6 \\
\hline Vitamin $B_{12}, \mu g$ & 6.7 & 8.1 & 9.0 & 6.9 & 2 \\
\hline Vitamin $D, \mu \mathrm{g}$ & 6.8 & 10.4 & 8.1 & 9.7 & $7.5 / 10^{*}$ \\
\hline Iron, mg & 10.6 & 13.3 & 11.4 & 11.1 & 9 \\
\hline \multicolumn{6}{|l|}{ Scenario 5} \\
\hline Energy, MJ & 10.4 & 8.9 & 10.9 & 9.4 & \\
\hline Saturated fat, E\% & 13.5 & 11.0 & 13.0 & 12.9 & $\leq 10$ \\
\hline Vitamin $\mathrm{B}_{6}, \mathrm{mg}$ & 1.8 & 2.0 & 1.9 & 2.4 & 1.6 \\
\hline Vitamin $B_{12}, \mu g$ & 4.9 & 6.4 & 7.9 & 6.2 & 2 \\
\hline Vitamin D, $\mu \mathrm{g}$ & 3.7 & 7.6 & 7.1 & 7.8 & $7.5 / 10^{*}$ \\
\hline Iron, mg & 10.8 & 13.7 & 12.1 & 11.9 & 9 \\
\hline
\end{tabular}

*age $\geq 61$ years

\subsection{Children}

The habitual intake of meat and fish in Danish, Norwegian and Swedish children can be seen in Table 11. The figures for children are similar across the four countries with the lowest intake of fish in Denmark, and the highest intake of meat in Sweden. 
Table 11. Habitual diet of children, Scenario 1. Intake of meat and fish (avg. g/d)

\begin{tabular}{lrrrr}
\hline & $\begin{array}{r}\text { Denmark 4-9y } \\
(\mathbf{n = 2 9 8})\end{array}$ & Finland & $\begin{array}{r}\text { Norway 9y } \\
(\mathbf{n = 8 1 0 )}\end{array}$ & $\begin{array}{r}\text { Sweden 8y } \\
\text { (n=1479) }\end{array}$ \\
\hline Meat, total & 89 & - & 85 & 123 \\
Red meat & 39 & - & 38 & 79 \\
White meat & 11 & - & 7 & 16 \\
Processed meat & 40 & - & 39 & 28 \\
Fish & 11 & - & 27 & 18 \\
\hline
\end{tabular}

The distribution of macronutrients in the five scenarios for Danish, Norwegian and Swedish children can be seen in Table 12. The macronutrient distribution for children is similar across the three countries with fat energy percentage above 30 in the habitual diet. The distribution of macronutrients changes very little throughout the five scenarios.

Table 12. Macronutrient distribution in children in Scenarios 1-5

\begin{tabular}{|c|c|c|c|c|c|}
\hline & $\begin{array}{r}\text { Denmark 4-9y } \\
(n=298)\end{array}$ & Finland & $\begin{array}{r}\text { Norway 9y } \\
(n=810)\end{array}$ & $\begin{array}{r}\text { Sweden 8y } \\
(n=1479)\end{array}$ & NNR 2004 \\
\hline \multicolumn{6}{|l|}{ Scenario 1} \\
\hline Protein, E\% & 14.0 & - & 14.1 & 15.0 & $10-20$ \\
\hline Fat, E\% & 34.0 & - & 31.4 & 31.6 & 30 \\
\hline Carbohydrate, E\% & 52.0 & - & 54.5 & 53.4 & $50-60$ \\
\hline \multicolumn{6}{|l|}{ Scenario 2} \\
\hline Protein, E\% & 14.7 & - & 15.1 & 14.8 & $10-20$ \\
\hline Fat, E\% & 32.7 & - & 29.8 & 31.1 & 30 \\
\hline Carbohydrate, E\% & 52.6 & - & 55.1 & 53.5 & $50-60$ \\
\hline \multicolumn{6}{|l|}{ Scenario 3} \\
\hline Protein, E\% & 13.5 & - & 13.6 & 15.3 & $10-20$ \\
\hline Fat, E\% & 31.8 & - & 29.4 & 32.1 & 30 \\
\hline Carbohydrate, E\% & 54.7 & - & 57.0 & 54.4 & $50-60$ \\
\hline \multicolumn{6}{|l|}{ Scenario 4} \\
\hline Protein, E\% & - & - & - & 14.7 & $10-20$ \\
\hline Fat, E\% & - & - & - & 30.9 & 30 \\
\hline Carbohydrate, E\% & - & - & - & 53.5 & $50-60$ \\
\hline \multicolumn{6}{|l|}{ Scenario 5} \\
\hline Protein, E\% & - & - & - & 15.5 & $10-20$ \\
\hline Fat, E\% & - & - & - & 32.6 & 30 \\
\hline Carbohydrate, E\% & - & - & - & 55.2 & $50-60$ \\
\hline
\end{tabular}

Table 13 provides data on energy intake and contribution of saturated fat and intakes of selected micronutrients in children. The figures for children are similar across the three countries with very little changes throughout the five scenarios. Contributions from fat and saturated fat are higher than recommendations (Nordic Council of Ministers, 2004), but do not change markedly throughout the five scenarios. Intakes of vitamin D and iron are in general below recommendations (Nordic Council of Ministers, 2004), and do not change to any considerable degree with decreased intake of meat. 
Table 13. Energy and micronutrient intakes and contribution of fat and saturated fat in children in Scenarios 1-5

\begin{tabular}{|c|c|c|c|c|c|}
\hline & $\begin{array}{r}\text { Denmark 4-9y } \\
(n=298) \\
\end{array}$ & Finland & $\begin{array}{r}\text { Norway 9y } \\
(n=810)\end{array}$ & $\begin{array}{r}\begin{array}{r}\text { Sweden } 8 y \\
(n=1479)\end{array} \\
\end{array}$ & NNR 2004 \\
\hline \multicolumn{6}{|l|}{ Scenario 1} \\
\hline Energy, MJ & 8.0 & - & 8.3 & 9.4 & \\
\hline Saturated fat, E\% & 14.4 & - & 13.7 & 14.3 & $\leq 10$ \\
\hline Vitamin $\mathrm{B}_{6}, \mathrm{mg}$ & 1.3 & - & - & 1.5 & 1.0 \\
\hline Vitamin $B_{12}, \mu g$ & 5.0 & - & - & 4.4 & 1.3 \\
\hline Vitamin $D, \mu g$ & 2.3 & - & 2.8 & 4.4 & 7.5 \\
\hline Iron, mg & 8.0 & - & 8.8 & 8.3 & 9 \\
\hline \multicolumn{6}{|l|}{ Scenario 2} \\
\hline Energy, MJ & 7.9 & - & 8.2 & 9.4 & \\
\hline Saturated fat, E\% & 13.8 & - & 12.9 & 14.0 & $\leq 10$ \\
\hline Vitamin $\mathrm{B}_{6}, \mathrm{mg}$ & 1.4 & - & - & 1.5 & 1.0 \\
\hline Vitamin $B_{12}, \mu g$ & 5.0 & - & - & 4.8 & 1.3 \\
\hline Vitamin D, $\mu \mathrm{g}$ & 3.6 & - & 3.3 & 5.2 & 7.5 \\
\hline Iron, mg & 7.5 & - & 8.4 & 8.0 & 9 \\
\hline \multicolumn{6}{|l|}{ Scenario 3} \\
\hline Energy, MJ & 8.0 & - & 8.3 & 9.4 & \\
\hline Saturated fat, E\% & 13.7 & - & 12.9 & 14.6 & $\leq 10$ \\
\hline Vitamin $\mathrm{B}_{6}, \mathrm{mg}$ & 1.3 & - & - & 1.5 & 1.0 \\
\hline Vitamin $B_{12}, \mu g$ & 4.1 & - & - & 4.5 & 1.3 \\
\hline Vitamin $D, \mu g$ & 2.2 & - & 3.0 & 4.5 & 7.5 \\
\hline Iron, mg & 7.6 & - & 8.4 & 8.4 & 9 \\
\hline \multicolumn{6}{|l|}{ Scenario 4} \\
\hline Energy, MJ & - & - & - & 9.4 & \\
\hline Saturated fat, E\% & - & - & - & 13.8 & $\leq 10$ \\
\hline Vitamin $\mathrm{B}_{6}, \mathrm{mg}$ & - & - & - & 1.5 & 1.0 \\
\hline Vitamin $B_{12}, \mu g$ & - & - & - & 5.0 & 1.3 \\
\hline Vitamin $D, \mu g$ & - & - & - & 5.8 & 7.5 \\
\hline Iron, mg & - & - & - & 7.9 & 9 \\
\hline \multicolumn{6}{|l|}{ Scenario 5} \\
\hline Energy, MJ & - & - & - & 9.4 & \\
\hline Saturated fat, E\% & - & - & - & 14.8 & $\leq 10$ \\
\hline Vitamin $\mathrm{B}_{6}, \mathrm{mg}$ & - & - & - & 1.5 & 1.0 \\
\hline Vitamin $B_{12}, \mu g$ & - & - & - & 5.6 & 1.3 \\
\hline Vitamin $D, \mu \mathrm{g}$ & - & - & - & 4.5 & 7.5 \\
\hline Iron, mg & - & - & - & 8.6 & 9 \\
\hline
\end{tabular}

\subsection{Adolescents}

The habitual intake of meat and fish in Danish, Finnish, Norwegian and Swedish adolescents can be seen in Table 14. The figures for adolescents are similar across the four countries with the lowest intake of fish in Denmark, and the highest intake of meat in Sweden. 
Table 14. Habitual diet of adolescents, Scenario 1. Intake of meat and fish (avg. g/d)

\begin{tabular}{lrrrr}
\hline & $\begin{array}{r}\text { Denmark 10-17y } \\
(\mathbf{n = 3 7 7})\end{array}$ & $\begin{array}{r}\text { Finland 13-14y } \\
\text { (n=306) }\end{array}$ & $\begin{array}{r}\text { Norway 13y } \\
\text { (n=1005) }\end{array}$ & $\begin{array}{r}\text { Sweden 11y } \\
\text { (n=1016) }\end{array}$ \\
\hline Meat, total & 104 & 95 & 95 & 135 \\
Red meat & 57 & 44 & 51 & 89 \\
White meat & 15 & 23 & 8 & 17 \\
Processed meat & 32 & 28 & 36 & 30 \\
Fish & 9 & 15 & 24 & 19 \\
\hline
\end{tabular}

The distribution of macronutrients in the five scenarios for Danish, Finnish, Norwegian and Swedish adolescents can be seen in Table 15. The macronutrient distribution for adolescents is similar across the four countries with fat energy percentage above 30 in the habitual diet. The distribution of macronutrients changes very little throughout the five scenarios.

Table 15. Macronutrient distribution in adolescents in Scenarios 1-5

\begin{tabular}{|c|c|c|c|c|c|}
\hline & $\begin{array}{r}\text { Denmark } 10- \\
17 y \\
(n=377)\end{array}$ & $\begin{array}{r}\text { Finland 13- } \\
14 y \\
(n=306)\end{array}$ & $\begin{array}{r}\text { Norway 13y } \\
(n=1005)\end{array}$ & $\begin{array}{r}\text { Sweden 11y } \\
(n=1016)\end{array}$ & NNR 2004 \\
\hline \multicolumn{6}{|l|}{ Scenario 1} \\
\hline Protein, E\% & 14.5 & 16.3 & 14.2 & 15.7 & $10-20$ \\
\hline Fat, E\% & 32.9 & 29.9 & 30.6 & 31.5 & 30 \\
\hline Carbohydrate, E\% & 52.5 & 53.7 & 55.2 & 52.8 & $50-60$ \\
\hline \multicolumn{6}{|l|}{ Scenario 2} \\
\hline Protein, E\% & 15.1 & 16.9 & 15.1 & 15.6 & $10-2 C$ \\
\hline Fat, E\% & 31.7 & 29.3 & 29.4 & 32.3 & 30 \\
\hline Carbohydrate, E\% & 53.2 & 53.7 & 55.5 & 54.0 & $50-60$ \\
\hline \multicolumn{6}{|l|}{ Scenario 3} \\
\hline Protein, E\% & 14.1 & 15.8 & 13.8 & 16.0 & $10-20$ \\
\hline Fat, E\% & 31.4 & 28.4 & 29.0 & 32.3 & 30 \\
\hline Carbohydrate, E\% & 54.5 & 55.6 & 57.3 & 54.0 & $50-60$ \\
\hline \multicolumn{6}{|l|}{ Scenario 4} \\
\hline Protein, E\% & 15.1 & 16.9 & 15.1 & 15.2 & $10-20$ \\
\hline Fat, E\% & 31.6 & 29.2 & 29.3 & 30.7 & 30 \\
\hline Carbohydrate, E\% & 53.3 & 53.8 & 55.6 & 52.8 & $50-60$ \\
\hline \multicolumn{6}{|l|}{ Scenario 5} \\
\hline Protein, E\% & 13.7 & 15.7 & 13.8 & 16.2 & $10-20$ \\
\hline Fat, E\% & 31.1 & 28.1 & 29.0 & 32.7 & 30 \\
\hline Carbohydrate, E\% & 55.2 & 56.1 & 57.3 & 54.7 & $50-60$ \\
\hline
\end{tabular}

Table 16 provides data on energy intake and contribution of saturated fat and intakes of selected micronutrients in adolescents. The figures for adolescents are similar across the four countries with very little changes throughout the five scenarios. Contributions from fat and saturated fat are higher than recommendations (Nordic Council of Ministers, 2004), and do not change markedly throughout the five scenarios. Intakes of vitamin $\mathrm{D}$ and iron are in general below recommendations 
(Nordic Council of Ministers, 2004), and do not decreased noticeably with decreased intake of meat.

Table 16. Energy and micronutrient intakes and contribution of fat and saturated fat in adolescents in Scenarios 1-5

\begin{tabular}{|c|c|c|c|c|c|}
\hline & $\begin{array}{r}\text { Denmark 10- } \\
17 y \\
(n=377)\end{array}$ & $\begin{array}{r}\text { Finland 13- } \\
14 y \\
(n=306)\end{array}$ & $\begin{array}{r}\text { Norway 13y } \\
(n=1005)\end{array}$ & $\begin{array}{r}\text { Sweden 11y } \\
(n=1016)\end{array}$ & $\begin{array}{r}\text { NNR } 2004 \\
(F / M)\end{array}$ \\
\hline \multicolumn{6}{|l|}{ Scenario 1} \\
\hline Energy, MJ & 8.5 & 7.4 & 8.9 & 7.4 & \\
\hline Saturated fat, E\% & 13.8 & 11.0 & 13.5 & 14.0 & $\leq 10$ \\
\hline Vitamin $\mathrm{B}_{6}, \mathrm{mg}$ & 1.5 & 1.8 & - & 1.5 & $1.1 / 1.3$ \\
\hline Vitamin $B_{12}, \mu g$ & 4.6 & 4.5 & - & 4.4 & $2 / 2$ \\
\hline Vitamin $D, \mu g$ & 2.4 & 5.7 & 2.5 & 4.1 & 7.5 \\
\hline Iron, mg & 8.7 & 9.6 & 9.4 & 8.3 & $15 / 11$ \\
\hline \multicolumn{6}{|l|}{ Scenario 2} \\
\hline Energy, MJ & 8.4 & 7.4 & 8.8 & 7.3 & \\
\hline Saturated fat, E\% & 13.8 & 10.6 & 12.8 & 13.9 & $\leq 10$ \\
\hline Vitamin $\mathrm{B}_{6}, \mathrm{mg}$ & 1.5 & 1.9 & - & 1.6 & $1.1 / 1.3$ \\
\hline Vitamin $B_{12}, \mu \mathrm{g}$ & 4.6 & 5.1 & - & 4.8 & $2 / 2$ \\
\hline Vitamin $D, \mu g$ & 3.7 & 6.7 & 3.0 & 5.2 & 7.5 \\
\hline Iron, mg & 8.3 & 9.6 & 9.1 & 8.1 & $15 / 11$ \\
\hline \multicolumn{6}{|l|}{ Scenario 3} \\
\hline Energy, MJ & 8.5 & 7.4 & 8.9 & 7.4 & \\
\hline Saturated fat, E\% & 13.4 & 10.5 & 12.9 & 14.4 & $\leq 10$ \\
\hline Vitamin $\mathrm{B}_{6}, \mathrm{mg}$ & 1.4 & 1.8 & - & 1.6 & $1.1 / 1.3$ \\
\hline Vitamin $B_{12}, \mu g$ & 3.9 & 4.5 & - & 4.4 & $2 / 2$ \\
\hline Vitamin $D, \mu g$ & 2.3 & 5.8 & 2.6 & 4.2 & 7.5 \\
\hline Iron, mg & 8.4 & 9.7 & 9.1 & 8.5 & $15 / 11$ \\
\hline \multicolumn{6}{|l|}{ Scenario 4} \\
\hline Energy, MJ & 8.4 & 7.4 & 8.8 & 7.3 & \\
\hline Saturated fat, E\% & 13.3 & 10.5 & 12.7 & 13.5 & $\leq 10$ \\
\hline Vitamin $\mathrm{B}_{6}, \mathrm{mg}$ & 1.5 & 1.9 & - & 1.5 & $1.1 / 1.3$ \\
\hline Vitamin $B_{12}, \mu \mathrm{g}$ & 4.8 & 5.2 & - & 5.0 & $2 / 2$ \\
\hline Vitamin $D, \mu g$ & 4.3 & 6.9 & 3.1 & 5.7 & 7.5 \\
\hline Iron, mg & 8.2 & 9.5 & 9.0 & 7.8 & $15 / 11$ \\
\hline \multicolumn{6}{|l|}{ Scenario 5} \\
\hline Energy, MJ & 8.5 & 7.4 & 8.9 & 7.4 & \\
\hline Saturated fat, E\% & 13.2 & 10.4 & 12.9 & 14.6 & $\leq 10$ \\
\hline Vitamin $\mathrm{B}_{6}, \mathrm{mg}$ & 1.4 & 1.8 & - & 1.6 & $1.1 / 1.3$ \\
\hline Vitamin $B_{12}, \mu g$ & 3.8 & 4.5 & - & 4.5 & $2 / 2$ \\
\hline Vitamin $D, \mu g$ & 2.3 & 5.8 & 2.6 & 4.2 & 7.5 \\
\hline Iron, mg & 8.3 & 9.6 & 9.1 & 8.6 & $15 / 11$ \\
\hline
\end{tabular}





\section{Discussion}

\subsection{Main findings}

The habitual intakes of meat and fish for women, men, children and adolescents differed across the four Nordic countries involved in the present project with the highest intake of meat in Norway, and the lowest intake of fish in Denmark for adults and with the highest intake of meat in Sweden, and the lowest intake of fish in Denmark for children and adolescents.

The macronutrient distribution for women, men, children and adolescents was quite similar across the four countries with fat energy percentage above 30, and carbohydrate energy percentage below 50 for all except Danish and Finnish women, in the habitual diet. The distribution of macronutrients changed very little throughout the five scenarios, where scenario 1 was the average habitual diet and the following scenarios mirrored the levels of meat intake recommended by the World Cancer Research Fund (WCRF) as the personal recommendation and the public health goal, respectively; scenario 2 was the average habitual diet where the habitual red meat intake was reduced to $70 \mathrm{~g} / \mathrm{d}$ and the intake of processed meat intake was $0 \mathrm{~g} / \mathrm{d}$. The meat was substituted with $\mathrm{X} g$ white meat/fish; scenario 3 was the average habitual diet where the habitual red meat intake was reduced to $70 \mathrm{~g} / \mathrm{d}$ and the intake of processed meat intake was $0 \mathrm{~g} / \mathrm{d}$. The meat was substituted with a proportional amount of other food products but meat; scenario 4 the average habitual diet where the habitual red meat intake was reduced to $43 \mathrm{~g} / \mathrm{d}$ and the intake of processed meat intake was $0 \mathrm{~g} / \mathrm{d}$. The meat was substituted with X $\mathrm{g}$ white meat/fish; and scenario 5 was the average habitual diet where the habitual red meat intake was reduced to $43 \mathrm{~g} / \mathrm{d}$ and the intake of processed meat intake was $0 \mathrm{~g} / \mathrm{d}$. The meat was substituted with a proportional amount of other food products but meat.

Regarding intakes of micronutrients and contribution of fat and saturated fat, the figures for women, men, children and adolescents were similar across the four countries with surprisingly little changes throughout the five scenarios. Contributions from fat and saturated fat were higher than recommended (Nordic Council of Ministers, 2004), but did not change markedly throughout the five scenarios. Mean intakes of vitamin D were below recommendations (Nordic Council of Ministers, 
2004), in women, children and adolescents, and Danish men, and did not decrease with reduced intakes of meat. Mean intakes of iron were below recommendations (Nordic Council of Ministers, 2004) in women, children and adolescents, and did not decrease noticeably with reduced intake of meat.

The present study showed that the dietary intake of meat and meat products in the four Nordic countries estimated with the applied dietary methods was relatively low - and actually so low in comparison with the recommended levels suggested by the WCRF that the modeling applied in the present study meant relatively low reductions of intake of meat and meat products.

Only men from Denmark, Sweden, and Norway had average habitual daily intakes of red meat exceeding $70 \mathrm{~g}$ as well as Swedish children and adolescents. Thus, all women and most children and adolescents as well as men from Finland had average mean habitual daily intakes of red meat below $70 \mathrm{~g}$.

\subsection{Intake of meat and meat products and health}

The basis for the WCRF recommendations was a systematic literature review mainly based on prospective cohort studies. WCRF concluded that there is convincing evidence that both red meat and processed meat increase risk of developing colorectal cancer (World Cancer Research Fund and American Institute for Cancer Research, 2007). A doseresponse relationship was found in cohort studies. However, since the evidence originates from epidemiological studies, they do not document unambiguously that the relationship is causal (The German Federal Institute for Risk Assessment, 2009). And, in several later reviews of prospective epidemiological studies on an association between colorectal cancer and red and processed meat as well as in meta-analyses (Alexander and Cushing, 2011; Chan et al., 2011; Smolinska and Paluszkiewicz, 2010; Alexander et al., 2010; Chan et al., 2011; Magalhaes et al., 2012; Bastide et al., 2011; Alexander et al., 2011; Chan et al., 2011; Larsson and Wolk, 2006), it was concluded that there is a significant association, but that there is probably insufficient evidence to conclude a causal relationship. This has left the discussion open as to the recommended level of intake of meat and meat products.

Other systematic reviews from FAO/WHO and American Dietetic Association have concluded that there is convincing (Food and Agriculture Organization World Health Organization, 2009) or probable (Van et al., 
2008) evidence that saturated fatty acids increase risk of coronary heart disease. Furthermore, WHO/FAO (Food and Agriculture Organization World Health Organization, 2009) concluded that there is probable evidence that intake of trans fatty acids increase the risk for developing type 2 diabetes, and that there is possible evidence that intake of saturated fatty acids increase the risk for developing type 2 diabetes.

The studies that have formed the basis of these expert reports often are derived from other countries than the Nordic countries. This signifies that the studies are mainly derived from populations with different lifestyles, including different dietary intakes. Also, most of the studies have used FFQs as dietary assessment methods to assess food and nutrient intakes. It is well recognized that FFQs are suitable and largely applied in large population studies - however, they may suffer from various drawbacks such as the lack of specificity of food products assessed (Thompson and Subar, 2008).

\subsection{Intake of meat and meat products and nutrients}

The mechanisms for possible adverse health effects of meat and meat products are mainly related to nutrients such as saturated fat, trans fat, and chemicals produced during processing such as nitroso compounds, heterocyclic amines, polycyclic aromatic hydrocarbons, and sodium ( $\mathrm{Na}$ ) and iron (Fe) (World Cancer Research Fund and American Institute for Cancer Research, 2007; Bastide et al., 2011). At the same time, the mechanisms for the beneficial health effects of meat and meat products are also related to their contribution of certain nutrients such as protein, $\mathrm{Fe}, \mathrm{Zn}$ (Stoltzfus, 2001; Tetens et al., 2007; World Health Organization Food and Agriculture Organization and United Nations University, 2007). Thus, the intake of nutrients associated with meat intake - those that we are recommended to reduce and those that we are recommended to increase are to be weighed together (Millward and Garnett, 2010).

The value of meat as a rich source of bioavailable macro- and micronutrients is distinct, and the nutritional value of meat and meat products should be based on an overall weighing of both nutrients that are supplied in too high amounts and too low amounts according to current recommendations. Many meat products are a major source of saturated fat in the diet and a high intake of saturated fat has convincingly been linked to the circulatory diseases associated with increasing BMI. Consumption of red and processed meat has been associated with an increased risk of colorectal cancer in adults (World Cancer Research Fund 
and American Institute for Cancer Research, 2007), however not in all studies (Key et al., 2009).

The literature on the effects of meat intakes in children is remarkably restricted. In low-income countries, there is little difference in linear growth between children with negligible amounts of dietary meat or with meat-free lacto-ovo vegetarian diets and that of the omnivore healthy population (Sanders, 1999; O'Connell et al., 1989). However, for vegan preschool children, slower growth has been observed (Sanders and Manning, 1992).

Inadequate intakes of bioavailable iron may result in deficiency in tissue iron, which may be one of the causes of anaemia (iron-deficiency anaemia). However, anaemia may also be caused by vitamin B12 and folate deficiency. Impaired work performance in adults, and poor motor and possibly cognitive development in children are possible long-term adverse consequences of severe iron-deficiency and anaemia. Additionally, increased perinatal, maternal and child mortality may be caused by very severe deficiency and anaemia (Stoltzfus, 2001).

Regulation of iron homeostasis occurs only through regulation of iron absorption, as there are no specific excretory pathways in the body for iron. Absorption of heme-iron, which is mainly found in meat and meat products, depends only to a small degree on the composition of the food. The absorption of non-heme-iron, which is found mostly in vegetable food sources, is highly dependent on the content of vitamin C, and muscle protein (meat, fish), that increases absorption and of the content of calcium, phosphates, especially phytate and certain polyphenols, that inhibits absorption (Scientific Advisory Committee on Nutrition, 2010). Additionally, the absorption of iron is highly dependent of the iron status of the individual with very little absorption if iron stores are replete (Hunt and Roughead, 2000).

Meat intake is an important determinant of iron stores, with lower serum ferritin concentrations in vegetarians compared with omnivores (Donovan and Gibson, 1995). However, vegetarians do not have a greater incidence of iron-deficiency anaemia than omnivores (Hunt, 2002).

When meat is part of the diet, it may have a marked influence on overall dietary protein content (Table 2), and in addition will also improve overall dietary protein quality in terms of digestibility and biological value. Protein digestibility corrected amino acid score (PDCAAS) is higher for meat than for many plant protein sources. However, for many mixed plant-food-based diets, PDCAAS is high. Diets based on cereals, or especially on starchy roots only, and little else will have a low PDCAAS (Schaafsma, 2000). 
Elderly adults are the group most vulnerable to low-protein diets because they are the group with the highest protein requirement relative to energy requirements because of a higher reduction in energy requirements than protein requirements with increasing age. Dietary protein has been associated with both favourable anabolic influences on bone health through insulin-like growth factor-1 and unfavourable influences on bone health as a source of acid due to oxidation of Scontaining amino acids, cysteine and methionine, which may induce a calciuria (World Health Organization Food and Agriculture Organization and United Nations University, 2007). However, the balance between these effects is still being debated.

\subsection{Our results - dietary patterns}

The present study showed that the dietary intake of meat and meat products estimated with the applied dietary methods was relatively low - and actually so low in comparison with the recommended levels suggested by the WCRF that the modeling applied in the present study meant relatively low reductions of intake of meat and meat products.

Only men from Denmark and Sweden (74 g), and Norway (72 g) had average habitual daily intakes of red meat exceeding $70 \mathrm{~g}$ as well as Swedish children ( $79 \mathrm{~g}$ ) and adolescents ( $89 \mathrm{~g}$ ). Thus all women and most children and adolescents as well as men from Finland (48 g) had average habitual daily intakes of red meat below $70 \mathrm{~g}$.

In the present study, the macronutrient distribution for the average habitual diet for women, men, children and adolescents was rather similar across the four countries with fat energy percentage above the recommendation of 30 (Nordic Council of Ministers, 2004), and carbohydrate energy percentage below the recommended range of 50-60 (Nordic Council of Ministers, 2004) for all except Finnish women, in the habitual diet. The distribution of macronutrients changed very little throughout the five scenarios. Energy percentage of saturated fat in the habitual diet varied from 11 to 15 , which is above the recommendation of $\leq 10$ (Nordic Council of Ministers, 2004), and it remained within this range in all five scenarios. Protein energy percentages was within the recommended range of 10-20 (Nordic Council of Ministers, 2004) in the average habitual diet of all four countries in women, men, children and adolescents, and it remained within this recommended range throughout the five scenarios. 
In the present study, data for elderly were not being analysed separately as we only had data for men and women to the age of 75 years.

\subsection{Our results - nutrients}

In the present study no decrease in protein energy percentages in the different scenarios of decreased intake of meat in either women, men, children or adolescents was seen and all protein energy percentages were within the recommendations (Nordic Council of Ministers, 2004). Overall there seems to be little nutritional concern among the general population in the age range from 4 to 75 years of age in the 4 Nordic countries for lower protein intakes with reduced meat consumption to the level suggested by the WCRF.

In the present study, habitual intakes of vitamin D were far below recommendations (Nordic Council of Ministers, 2004) for children, adolescents, women, and for Danish men in the present study. The estimated intake of vitamin D differed little through the five different scenarios of reduced meat intake. However, in scenarios 2 and 4, where the reduction of meat intake was substituted by similar amounts of white meat and fish, the intake of vitamin D increased, although not meeting the recommended levels.

Habitual intakes of iron were below recommendations (Nordic Council of Ministers, 2004) for children, adolescents, and for Danish women, but not for men. The estimated intake of iron differed remarkably little between the five different scenarios of reduced meat intake. Thus, reducing red meat intake to $70 \mathrm{~g} / \mathrm{d}$ or $43 \mathrm{~g} / \mathrm{d}$ and reducing intake of processed meat to $0 \mathrm{~g} / \mathrm{d}$ has little impact on total iron intakes. However, it has to be considered that bioavailability of iron in the diet may decrease with the decreased meat intake. This aspect was not possible to study further in the present project with the data available.

\subsection{Methodological issues}

In all four countries, data were provided from representative national samples, which makes this study unique. However, the year of data collection varied from 2000 in Norwegian children to 2010-2011 in Norwegian and Swedish adults. The participation rate differed from $36 \%$ and $37 \%$ in adults in Sweden and Norway, respectively to $83 \%$ in Norwegian children. It is of note that the four countries evaluated under- 
reporting and over-reporting differently. However, the degree of underreporting/over-reporting was comparable in the data.

The dietary assessment methods used in this project differed across the four countries. Three countries used food record with either seven days (Denmark) or four days (Sweden, Norway's UNGKOST), and two countries used recalls with either 48 hours (Finland) or $2 \times 24$ nonconsecutive hours (Norway's Norkost). Different age groups, especially in children and adolescents, were included in the study. Further, it should be noted that the four countries have used their country specific food composition databases in the processing of data.

The aim of this study was to estimate the overall nutritional consequences of reducing meat intake at group level. No attempts were therefore taken to do any further modelling to estimate whether the proportion of individuals with low nutrient intakes would increase if average meat intake is reduced. However, reducing average red and processed meat intake from the current level to the WCRF population level of $300 \mathrm{~g}$ per week only changed average nutrient intakes marginally suggesting that the proportion of participants in these representative studies with a poor nutrient intake would not increase substantially.

Although dietary modelling and calculations were carried out similarly in the four Nordic countries, there were some differences in the approach of calculating meat weight across the countries. In Denmark, Finland and Norway, the calculation of the final amount of meat consumed (in grams) differed by type of meat. Meat, poultry, minced meat and liver were reported in raw weight and $20 \%$ weight loss was used to convert the amount of raw meat to amount as eaten. Processed meat like cold cuts sausages, slices of ham etc. and liver paste was reported in product weight (as eaten). In Sweden, the final amount of meat (in grams) was reported as eaten for all types of meat. Another difference was that Denmark and Norway did not consider nutrient losses from cooking, whereas Finland and Sweden did. These methodological differences should be kept in mind when comparing mean values across the countries, but it is considered that these differences will not influence the final conclusions since the scenarios are compared within each country.

Categorization of meat and meat products used in this project was based on the WCFR categorization, which however, is very broad, and mainly based on food frequency questionnaires (FFQs) as dietary assessment methods to assess food and nutrient intakes. Therefore, it was necessary to consider this aspect further in relation to this project. In this project the specific products available in the Nordic countries, espe- 
cially with respect to the processed meat products, was taken into consideration in the categorization of meat products (Table 4).

The issue on reducing processed meat is not merely related to a reduction in nutrient intake, but also to other issues, since a restriction of intake of processed meat may in general result in restriction of intake of salt and saturated fat. Processed meat may also contain sodium nitrate and their long-time storage may yield cholesterol oxidation products (Santarelli et al., 2008). 


\section{Conclusion}

With the aim to assess the overall nutritional consequences of lowering the average daily consumption of meat from current intake to the levels suggested by the WCRF with special emphasis on processed meat, the present study showed that the average meat intake in the Nordic countries in 18-75-y-old women and men, 4-9-y-old children, and 10-17-yold adolescents was not very high in comparison with the levels recommended by the WCRF. The largest change observed in the modelling of the dietary intake to the levels recommended by the WCRF was the exclusion of processed meat.

The overall impact on the average intake of nutrients that should be limited in the diet and on the nutrients that should be increased in the diet in relation to the nutrition recommendations differed little in the different scenarios studied, where white meat and fish or other food items substituted red meat and processed meat.

Despite methodological challenges when comparing nutritional data from representative samples from four different countries, results were markedly similar across countries

The present study suggests that the current habitual level of intake of meat is not far from the level suggested by WCRF at individual level. The greatest difference was the reduction in processed meat, with neglectible nutritional consequences of this reduction. 



\section{Acknowledgements}

We are very grateful to dietician Karin Hess Ygil for performing the nutritional modelling of the Danish diets. Furthermore, we wish to thank all those participating in ascertaining nutritional data in the dietary surveys in all four Nordic countries. 



\section{References}

Alexander DD and Cushing CA. Red meat and colorectal cancer: a critical summary of prospective epidemiologic studies. Obes. Rev. 2011:12:e472-e493.

Alexander DD, Miller AJ, Cushing CA, Lowe KA. Processed meat and colorectal cancer: a quantitative review of prospective epidemiologic studies. Eur. J Cancer Prev. 2010:19:328-341.

Alexander DD, Weed DL, Cushing CA, Lowe KA. Meta-analysis of prospective studies of red meat consumption and colorectal cancer. Eur. J Cancer Prev. 2011:20:293-307.

Anttolainen M, Javainainen J, Kaartinen P, Lahti-Koski M, Laurinen J, and Männistö S. The 1997 Dietary survey of Finnish Adults. 1998. Helsinki, Publications of the National Public Health Institute B8/1998.

Bastide NM, Pierre FH, Corpet DE. Heme iron from meat and risk of colorectal cancer: a meta-analysis and a review of the mechanisms involved. Cancer Prev. Res. (Phila) 2011:4:177-184.

Bergström. NLG, Nutrient Losses and Gains in the Preparation of Foods. 1994. National Food Agency report 32/1994.

Black AE. Critical evaluation of energy intake using the Goldberg cut-off for energy intake:basal metabolic rate. A practical guide to its calculation, use and limitations. Int. J. Obes. Relat Metab Disord. 2000b:24:1119-1130.

Black AE. The sensitivity and specificity of the Goldberg cut-off for EI:BMR for identifying diet reports of poor validity. Eur. J. Clin. Nutr. 2000a:54:395-404.

Chan DS, Lau R, Aune D, Vieira R, Greenwood DC, Kampman E et al. Red and processed meat and colorectal cancer incidence: meta-analysis of prospective studies. PLoS One 2011:6:e20456.

Danish Food Composition Databank ed70. DTU Food National Food Institute Technical University of Denmark. 2012.

Donovan UM and Gibson RS. Iron and zinc status of young women aged 14 to 19 years consuming vegetarian and omnivorous diets. J Am. Coll. Nutr 1995:14:463-472.

Food and Agriculture Organization World Health Organization. Fats and fatty acids in human nutrition. Proceedings of the Joint FAO/WHO Expert Consultation. November 10-14 2008. 2009. Geneva, Switzerland.

Goldberg GR, Black AE, Jebb SA, Cole TJ, Murgatroyd PR, Coward WA et al. Critical evaluation of energy intake data using fundamental principles of energy physiology: 1. Derivation of cut-off limits to identify under-recording. Eur. J. Clin. Nutr. 1991:45:569-581.

Helsedirektoratet. Utviklingen i norsk kosthold 2011 (IS-1947). 2011. Helsedirektoratet.

Hirvonen T, Mannisto S, Roos E, Pietinen P. Increasing prevalence of underreporting does not necessarily distort dietary surveys. Eur. J. Clin. Nutr. 1997:51:297-301.

Hoppu U, Kujala J, and Lahtisalo J. Nutrition and Wellbeing of Secondary School Pupils [In Finnish]. 2008. Helsinki, Publications of the National Public Health Institute B30/2008. 
Hoppu U, Lehtisalo J, Tapanainen H, Pietinen P. Dietary habits and nutrient intake of Finnish adolescents. Public Health Nutr. 2010:13:965-972.

Hunt JR. Moving toward a plant-based diet: are iron and zinc at risk? Nutr Rev. 2002:60:127-134.

Hunt JR and Roughead ZK. Adaptation of iron absorption in men consuming diets with high or low iron bioavailability. Am. JClin. Nutr 2000:71:94-102.

Information Centre of the Ministry of Agriculture and Forestry in Finland (Tike). Balance Sheet for Food Commodities 2010, preliminary. Matilda, Agricultural Statistics. 6/7/2011. 2012.

Key TJ, Appleby PN, Spencer EA, Travis RC, Roddam AW, Allen NE. Cancer incidence in vegetarians: results from the European Prospective Investigation into Cancer and Nutrition (EPIC-Oxford). Am. J. Clin. Nutr. 2009:89:1620S-1626S.

Kleemola P, Virtanen M, and Pietinen P. The 1992 Dietary Survey of Finnish Adults. Publications of the National Public Helath Institute B2/1994. 1992.

Larsson SC and Wolk A. Meat consumption and risk of colorectal cancer: a metaanalysis of prospective studies. Int. J Cancer 2006:119:2657-2664.

Magalhaes B, Peleteiro B, Lunet N. Dietary patterns and colorectal cancer: systematic review and meta-analysis. Eur. J Cancer Prev. 2012:21:15-23.

Männistö S, Laatikainen T, Helakorpi S, Valsta LM. Monitoring diet and diet-related chronic disease risk factors in Finland. Public Health Nutr. 2012:13:907-914.

Männistö S, Ovaskainen ML, and Valsta LM. The National Findiet 2002 Study. 2003. Helsinki, Publications of the National Public Health Institute B3/2003.

Millward DJ and Garnett T. Food and the planet: nutritional dilemmas of greenhouse gas emission reductions through reduced intakes of meat and dairy foods. Proceedings of the Nutrition Society 2010:69:103-118.

Nasjonalt råd for ernæring. Kostråd for å fremme folkehelsen og forebygge krosniske sykdommer. Metodologi og vitenskapelig kunnskapsgrunnlag. 2011.

Helsedirektoratet.

National Food Agency S. The National Food Administration's food database, version 26/01/2012. 2012

Nordic Council of Ministers (2004): Nordic Nutrition Recommendations 2004, 4 edn. Copenhagen: Nordic Council.

Norkost3. 2006.

O'Connell JM, Dibley MJ, Sierra J, Wallace B, Marks JS, Yip R. Growth of vegetarian children: The Farm Study. Pediatrics 1989:84:475-481.

Paturi M, Tapanainen H, Reinivuo H, and Pietinen P. The national FINDIET 2007 Survey. 2008:B23/2008. Helsinki, KTL-National Public Health Institute, Department of Health Promotion and Chronic Disease Prevention, Nutrition Unit. Publications of the National Public Health Institute.

Pedersen AN, Fagt S, Groth MV, Christensen T, Biltoft-Jensen A, Matthiessen J et al. [Dietary habits in Denmark 2003-2008. Main results]. 2010. National Food Institute, Technical University of Denmark.

Riksmaten adults unpublished results. 2010.

Sanders TA. The nutritional adequacy of plant-based diets. Proc. Nutr. Soc. 1999:58:265-269.

Sanders TAB and Manning J. The growth and development of vegan children. J Hum Nutr Diet 1992:5:21.

Santarelli RL, Pierre F, Corpet DE. Processed meat and colorectal cancer: a review of epidemiologic and experimental evidence. Nutr Cancer 2008:60:131-144. 
Schaafsma G. The protein digestibility-corrected amino acid score. J Nutr 2000:130:1865S-1867S.

Scientific Advisory Committee on Nutrition. Iron and Health. 2010. London, The Stationery Office.

Smolinska K and Paluszkiewicz P. Risk of colorectal cancer in relation to frequency and total amount of red meat consumption. Systematic review and meta-analysis. Arch. Med. Sci. 2010:6:605-610.

Statens Jordbruksverk. Livsmedelskonsumtion och näringsinnehåll tom 2010. 2012. Statistik Rapport 2012:01.

Stoltzfus RJ. Iron-deficiency anemia: reexamining the nature and magnitude of the public health problem. Summary: implications for research and programs. J Nutr 2001:131:701S.

Tetens I, Bendtsen KM, Henriksen M, Ersboll AK, Milman N. The impact of a meatversus a vegetable-based diet on iron status in women of childbearing age with small iron stores. Eur. J Nutr 2007:46:439-445.

The German Federal Institute for Risk Assessment . Study on meat intake and mortality. BfR Opinion No. 023/2009, 29 May 2009. 2009.

Thompson FE \& Subar AF (2008) Dietary assessment methodology. In Nutrition in the prevention and treatment of disease, ed. Coulston AM \& Boushey CJ, pp. 3-39. London: Elsevier Academic Press.

Van HL, McCoin M, Kris-Etherton PM, Burke F, Carson JA, Champagne CM et al. The evidence for dietary prevention and treatment of cardiovascular disease. J Am. Diet Assoc. 2008:108:287-331.

World Cancer Research Fund and American Institute for Cancer Research. Food, Nutrition, Physical Activity, and the Prevention of Cancer: a Global Perspective. 2007. Washington DC: AICR.

World Health Organization Food and Agriculture Organization and United Nations University. Protein and Amino Acid Requirements in Human Nutrition. Report of a Joint WHO/FAO/UNU Expert Consultation. WHO Technical Report Series no. 935. 2007. Geneva, WHO. 



\section{Sammenfatning}

The World Cancer Research Fond (WCRF) anbefalede i 2007, at forbrugernes indtag af rødt kød begrænses og at forarbejdet kød helt undgås. Anbefalingen var baseret på en systematisk gennemgang af den tilgængelige litteratur om sammenhængen mellem kødforbrug og kræft, især tarmkræft. Anbefalingen til enkeltpersoner var at indtage mindre end $500 \mathrm{~g}$ rødt kød pr. uge, svarende til 70 gram pr. dag og med meget lidt hvis noget- forarbejdet kød. Anbefalingen på gruppeniveau var et gennemsnitligt forbrug af rødt kød på højst $300 \mathrm{~g} \mathrm{rødt} \mathrm{kød} \mathrm{pr.} \mathrm{uge,} \mathrm{svarende}$ til 43 gram pr. dag og meget lidt - hvis noget - forarbejdet kød. Rødt kød betegner kødet fra dyr med fire ben, for eksempel svin, kvæg, får, geder, rådyr mm. Forarbejdet kød betegner kød, der er behandlet ved for eksempel saltning, lagring rygning, eller tilsat konserveringsmidler, for eksempel kødpålæg i form af skinke og pølse og bacon.

DTU Fødevareinstituttet har i en ny undersøgelse vurderet de ernæringsmæssige konsekvenser af at efterleve anbefalingen for befolkningen i de fire nordiske lande Norge, Sverige, Finland og Danmark. Befolkningen blev inddelt i fire grupper: kvinder 18-75 år, mænd 18-75 år, børn 4-9 år og unge 10-17 år. For hver gruppe blev kosten sat sammen på fem forskellige måder. Model 1 var den gennemsnitlige sædvanlige kost. Model 2 var den gennemsnitlige sædvanlige kost, hvor indtaget af rødt kød blev reduceret til 70 gram pr. dag og indtaget af forarbejdet kød til 0 gram pr. dag. Kødet blev erstattet med hvidt kød eller fisk. Model 3 var den gennemsnitlige sædvanlige kost, hvor indtaget af rødt kød blev reduceret til 70 gram pr. dag indtaget af forarbejdet kød til 0 gram pr. dag. Kødet blev erstattet med en proportional mængde af andre fødevarer end kød, for eksempel frugt, og grønt, mælkeprodukter og kornprodukter. Model 4 var den sædvanlige gennemsnitlige kost, hvor indtaget af rødt kød blev reduceret til 43 gram pr. dag og indtag af forarbejdet kød til 0 gram pr. dag. Kødet blev erstattet med hvidt kød eller fisk. Model 5 var den gennemsnitlige sædvanlige kost, hvor indtaget af rødt kød blev reduceret til 43 gram pr. dag og indtaget af forarbejdet kød til 0 gram pr. dag. Kødet blev erstattet med en proportional mængde af andre fødevarer end kød, for eksempel frugt, og grønt, mælkeprodukter og kornprodukter.

Undersøgelsen viser, at det nuværende gennemsnitlige indtag af kød i de nordiske lande for 18-75-årige kvinder og mænd, 4-9-årige børn og 
10-17-årige teenagere ikke var højt i forhold til de niveauer, WCRF anbefaler. Det gennemsnitlige sædvanlige indtag for rødt kød ligger således for kvinder på 30-47 g/d, mens det gennemsnitlige indtag af forarbejdet kød ligger for kvinder på 23-36 g/d. Den største ændring, modellerne gav anledning til, var således udelukkelsen af forarbejdet $\mathrm{k} ø \mathrm{~d}$, som WCRF anbefaler.

Undersøgelsen viser også, at det ikke har nogen nævneværdige ernæringsmæssige konsekvenser at efterleve WCRF's anbefalinger. I det omfang man skifter det røde kød ud med fisk, lyst kød eller andre fødevarer, får kosten ikke en ringere ernæringsmæssig sammensætning, når man sammenligner den med de nordiske ernæringsmæssige anbefalinger. Trods de metodemæssige udfordringer ved at sammenligne ernæringsmæssige data fra fire forskellige lande, var resultaterne meget ens på tværs af landene.

Denne undersøgelse tyder på, at det aktuelle indtag af kød i de Nordiske lande ikke er langt fra det niveau, WCRF har foreslået på individuelt niveau. Undersøgelsen viser også, at det ikke vil have nogen nævneværdige ernæringsmæssige konsekvenser at nedsætte indtaget af kød, hverken når det gælder rødt kød eller forarbejdet kød. 


\section{Appendix}

\subsection{Denmark}

\subsubsection{Women}

Table A1. Food intake in major food groups in 18 to 75 year-old women in Denmark, $n=1093$

\begin{tabular}{|c|c|c|c|c|c|}
\hline & Scenario 1 & Scenario 2 & Scenario 3 & Scenario 4 & Scenario 5 \\
\hline Meat, total, g/d & 86 & 74 & 62 & 72 & 58 \\
\hline Red meat, $\mathrm{g} / \mathrm{d}^{1}$ & 47 & 47 & 47 & 43 & 43 \\
\hline White meat, $\mathrm{g} / \mathrm{d}^{1}$ & 15 & 27 & 15 & 29 & 15 \\
\hline Processed meat, $\mathrm{g} / \mathrm{d}^{2}$ & 24 & 0 & 0 & 0 & 0 \\
\hline Fish and other seafood, $\mathrm{g} / \mathrm{d}^{3}$ & 16 & 28 & 17 & 30 & 17 \\
\hline Egg, $g / d^{3}$ & 9 & 9 & 9 & 9 & 9 \\
\hline Potatoes, rice and pasta, $\mathrm{g} / \mathrm{d}^{3}$ & 98 & 98 & 101 & 98 & 102 \\
\hline Bread and cereals, $\mathrm{g} / \mathrm{d}^{3}$ & 164 & 164 & 169 & 164 & 170 \\
\hline Fat spread (on bread), $\mathrm{g} / \mathrm{d}^{3}$ & 14 & 14 & 14 & 14 & 14 \\
\hline Fat used in cooking, $\mathrm{g} / \mathrm{d}^{3,4}$ & 21 & 21 & 21 & 21 & 22 \\
\hline Fruit and berries, $\mathrm{g} / \mathrm{d}^{3}$ & 226 & 226 & 234 & 226 & 235 \\
\hline Juice, $g / d^{3}$ & 69 & 69 & 71 & 69 & 72 \\
\hline Vegetables, $\mathrm{g} / \mathrm{d}^{3}$ & 159 & 159 & 165 & 159 & 165 \\
\hline Milk and milk products, $\mathrm{g} / \mathrm{d}^{3}$ & 279 & 279 & 289 & 279 & 290 \\
\hline Cheese, $\mathrm{g} / \mathrm{d}^{3}$ & 29 & 29 & 30 & 29 & 30 \\
\hline Beverages, $\mathrm{g} / \mathrm{d}^{3}$ & 2,155 & 2,155 & 2,231 & 2,155 & 2,243 \\
\hline Water, tea and coffee, $\mathrm{g} / \mathrm{d}^{3}$ & 1,779 & 1,779 & 1,842 & 1,779 & 1,851 \\
\hline Soda and fruit nectar, $\mathrm{g} / \mathrm{d}^{3}$ & 214 & 214 & 222 & 214 & 223 \\
\hline Alcohol, beer and vine, $\mathrm{g} / \mathrm{d}^{3}$ & 162 & 162 & 168 & 162 & 168 \\
\hline Snacks, sweets, ice cream, $\mathrm{g} / \mathrm{d}^{3}$ & 80 & 80 & 83 & 80 & 84 \\
\hline Other, $\mathrm{g} / \mathrm{d}^{3}$ & 43 & 43 & 44 & 43 & 45 \\
\hline
\end{tabular}

${ }^{1}$ Cooked meat and minced meat, calculated $20 \%$ weight loss from raw meat

${ }^{2}$ Prepared processed meat products, not weight loss calculated

${ }^{3}$ Measured in raw weight

${ }^{4}$ Incl. gravy/sauce

Table A2. Macronutrient intake 18 to 75 year-old women in Denmark, $n=1093$

\begin{tabular}{lrrrrr}
\hline & Scenario 1 & Scenario 2 & Scenario 3 & Scenario 4 & Scenario 5 \\
\hline Protein, E\% & 14.3 & 14.7 & 13.9 & 14.7 & 13.8 \\
Fat, E\% & 32.8 & 32.2 & 31.6 & 32.2 & 31.5 \\
Saturated fat, E\% & 13.6 & 13.3 & 13.2 & 13.2 & 13.1 \\
Monounsaturated fat, E\% & 11.6 & 11.2 & 11.0 & 11.2 & 10.9 \\
Polyunsaturated fat, E\% & 4.9 & 5.0 & 4.8 & 5.0 & 4.8 \\
Carbohydrate, E\% & 48.4 & 48.7 & 49.9 & 48.7 & 50.1 \\
Added sugar, E\% & 9.2 & 9.3 & 9.5 & 9.3 & 9.5 \\
Dietary fibre, g/MJ $^{1}$ & 2.6 & 2.6 & 2.6 & 2.6 & 2.6 \\
Alcohol, E\% & 4.5 & 4.5 & 4.6 & 4.5 & 4.6 \\
\hline
\end{tabular}

1 Dietary fibre is included in the total carbohydrate (E\%). 
Table A3. Micronutrient intake 18 to 75 year-old women in Denmark, $n=1093$

\begin{tabular}{|c|c|c|c|c|c|}
\hline & Scenario 1 & Scenario 2 & Scenario 3 & Scenario 4 & Scenario 5 \\
\hline Energy intake, MJ & 7.9 & 7.8 & 7.9 & 7.8 & 7.9 \\
\hline Dietary fibre, $\mathrm{g}$ & 20.11 & 20.09 & 20.74 & 20.08 & 20.83 \\
\hline Vitamin A, RE & 1075 & 894 & 901 & 890 & 897 \\
\hline Vitamin $D, \mu g$ & 3.0 & 3.9 & 2.9 & 4.1 & 2.9 \\
\hline Vitamin E, $\alpha$-TE & 7.8 & 8.1 & 8.0 & 8.1 & 8.0 \\
\hline Thiamine, mg & 1.2 & 1.1 & 1.1 & 1.1 & 1.1 \\
\hline Riboflavin, mg & 1.5 & 1.5 & 1.5 & 1.5 & 1.5 \\
\hline Niacin, NE & 29 & 30 & 28 & 30 & 28 \\
\hline Vitamin $\mathrm{B}_{6}, \mathrm{mg}$ & 1.5 & 1.5 & 1.5 & 1.5 & 1.5 \\
\hline Folate, $\mu \mathrm{g}$ & 350 & 346 & 352 & 346 & 353 \\
\hline Vitamin $B_{12}, \mu \mathrm{g}$ & 4.5 & 4.6 & 4.0 & 4.6 & 4.0 \\
\hline Vitamin C, mg & 134 & 130 & 134 & 130 & 135 \\
\hline Calcium, mg & 1,025 & 1,029 & 1,056 & 1,029 & 1,060 \\
\hline Phosphorus, mg & 1,256 & 1,253 & 1,246 & 1,252 & 1,243 \\
\hline Magnesium, mg & 320 & 321 & 326 & 321 & 326 \\
\hline Iron, mg & 9.0 & 8.7 & 8.8 & 8.7 & 8.8 \\
\hline Zinc, mg & 9 & 9 & 9 & 9 & 9 \\
\hline Copper, mg & 4.3 & 4.3 & 4.4 & 4.3 & 4.4 \\
\hline lodine $(\mu \mathrm{g})$ & 178 & 186 & 183 & 187 & 183 \\
\hline Selenium, $\mu \mathrm{g}$ & 38 & 41 & 36 & 41 & 36 \\
\hline Potassium, g & 3.1 & 3.1 & 3.2 & 3.1 & 3.2 \\
\hline
\end{tabular}

\subsubsection{Men}

Table A4. Food intake in major food groups in 18 to 75 year-old men in Denmark, $n=932$

\begin{tabular}{|c|c|c|c|c|c|}
\hline & Scenario 1 & Scenario 2 & Scenario 3 & Scenario 4 & Scenario 5 \\
\hline Meat, total, $\mathrm{g} / \mathrm{d}$ & 141 & 115 & 89 & 102 & 62 \\
\hline Red meat, $\mathrm{g} / \mathrm{d}^{1}$ & 74 & 70 & 70 & 43 & 43 \\
\hline White meat, $\mathrm{g} / \mathrm{d}^{1}$ & 19 & 45 & 19 & 59 & 19 \\
\hline Processed meat, $\mathrm{g} / \mathrm{d}^{2}$ & 49 & 0 & 0 & 0 & 0 \\
\hline Fish and other seafood, $\mathrm{g} / \mathrm{d}^{3}$ & 20 & 46 & 21 & 59 & 22 \\
\hline Egg, $g / d^{3}$ & 12 & 12 & 12 & 12 & 13 \\
\hline Potatoes, rice and pasta, $\mathrm{g} / \mathrm{d}^{3}$ & 156 & 156 & 166 & 156 & 170 \\
\hline Bread and cereals, $\mathrm{g} / \mathrm{d}^{3}$ & 219 & 219 & 233 & 219 & 239 \\
\hline Fat spread (on bread), $\mathrm{g} / \mathrm{d}^{3}$ & 24 & 24 & 25 & 24 & 26 \\
\hline Fat used in cooking, $\mathrm{g} / \mathrm{d}^{3,4}$ & 27 & 27 & 29 & 27 & 30 \\
\hline Fruit and berries, $\mathrm{g} / \mathrm{d}^{3}$ & 163 & 163 & 173 & 163 & 177 \\
\hline Juice, $g / d^{3}$ & 72 & 72 & 76 & 72 & 78 \\
\hline Vegetables, $\mathrm{g} / \mathrm{d}^{3}$ & 124 & 124 & 132 & 124 & 136 \\
\hline Milk and milk products, $\mathrm{g} / \mathrm{d}^{3}$ & 307 & 307 & 326 & 307 & 335 \\
\hline Cheese, $\mathrm{g} / \mathrm{d}^{3}$ & 38 & 38 & 40 & 38 & 41 \\
\hline Beverages, $\mathrm{g} / \mathrm{d}^{3}$ & 2,271 & 2,271 & 2,412 & 2,271 & 2,475 \\
\hline Water, tea and coffee, $\mathrm{g} / \mathrm{d}^{3}$ & 1,611 & 1,611 & 1,711 & 1,611 & 1,755 \\
\hline Soda and fruit nectar, $\mathrm{g} / \mathrm{d}^{3}$ & 255 & 255 & 271 & 255 & 278 \\
\hline Alcohol, beer and vine, $\mathrm{g} / \mathrm{d}^{3}$ & 405 & 405 & 430 & 405 & 441 \\
\hline Snacks, sweets, ice cream, $\mathrm{g} / \mathrm{d}^{3}$ & 90 & 90 & 96 & 90 & 98 \\
\hline Other, $\mathrm{g} / \mathrm{d}^{3}$ & 56 & 56 & 59 & 56 & 61 \\
\hline
\end{tabular}

${ }^{1}$ Cooked meat and minced meat, calculated $20 \%$ weight loss from raw meat

${ }^{2}$ Prepared processed meat products, not weight loss calculated

${ }^{3}$ Measured in raw weight

${ }^{4}$ Incl. gravy/sauce 
Table A5. Macronutrient intake 18 to 75 year-old men in Denmark, $\mathrm{n}=932$

\begin{tabular}{lrrrrr}
\hline & Scenario 1 & Scenario 2 & Scenario 3 & Scenario 4 & Scenario 5 \\
\hline Protein, E\% & 14.2 & 14.7 & 13.5 & 14.7 & 12.9 \\
Fat, E\% & 34.2 & 33.1 & 32.1 & 33.0 & 31.6 \\
Saturated fat, E\% & 14.4 & 13.9 & 13.8 & 13.7 & 13.5 \\
Monounsaturated fat, E\% & 12.1 & 11.5 & 11.1 & 11.4 & 10.7 \\
Polyunsaturated fat, E\% & 4.9 & 5.1 & 4.8 & 5.2 & 4.8 \\
Carbohydrate, E\% & 45.0 & 45.5 & 47.4 & 45.5 & 48.4 \\
Added sugar, E\% & 8.8 & 9.0 & 9.4 & 9.1 & 9.6 \\
$\quad$ Dietary fibre, g/MJ & 2.2 & 2.2 & 2.3 & 2.2 & 2.3 \\
Alcohol, E\% & 6.6 & 6.7 & 7.0 & 6.7 & 7.2 \\
\hline
\end{tabular}

${ }^{1}$ Dietary fibre is included in the total carbohydrate (E\%).

Table A6. Micronutrient intake 18 to 75 year-old men in Denmark, $n=932$

\begin{tabular}{|c|c|c|c|c|c|}
\hline & Scenario 1 & Scenario 2 & Scenario 3 & Scenario 4 & Scenario 5 \\
\hline Energy intake, MJ & 10.4 & 10.3 & 10.4 & 10.3 & 10.4 \\
\hline Dietary fibre, $\mathrm{g}$ & 22.56 & 22.53 & 23.78 & 22.47 & 24.27 \\
\hline Vitamin A, RE & 1436 & 1001 & 996 & 971 & 960 \\
\hline Vitamin D, $\mu \mathrm{g}$ & 3.8 & 5.8 & 3.7 & 6.8 & 3.7 \\
\hline Vitamin $E, \alpha-T E$ & 8.8 & 9.3 & 9.0 & 9.6 & 9.1 \\
\hline Thiamine, mg & 1.6 & 1.5 & 1.5 & 1.4 & 1.4 \\
\hline Riboflavin, mg & 1.9 & 1.9 & 1.9 & 1.8 & 1.8 \\
\hline Niacin, NE & 39 & 41 & 37 & 41 & 35 \\
\hline Vitamin $\mathrm{B}_{6}, \mathrm{mg}$ & 1.9 & 2.0 & 1.9 & 2.0 & 1.8 \\
\hline Folate, $\mu \mathrm{g}$ & 388 & 377 & 386 & 375 & 388 \\
\hline Vitamin $B_{12}, \mu g$ & 6.5 & 6.5 & 5.3 & 6.7 & 4.9 \\
\hline Vitamin $\mathrm{C}, \mathrm{mg}$ & 132 & 124 & 130 & 124 & 133 \\
\hline Calcium, mg & 1,124 & 1,131 & 1,180 & 1,130 & 1,199 \\
\hline Phosphorus, mg & 1,598 & 1,591 & 1,574 & 1,586 & 1,553 \\
\hline Magnesium, mg & 394 & 397 & 406 & 397 & 409 \\
\hline Iron, mg & 11.5 & 10.8 & 10.9 & 10.6 & 10.8 \\
\hline Zinc, mg & 12 & 12 & 12 & 11 & 11 \\
\hline Copper, mg & 3.5 & 3.5 & 3.6 & 3.5 & 3.7 \\
\hline lodine $(\mu \mathrm{g})$ & 214 & 232 & 223 & 240 & 225 \\
\hline Selenium, $\mu \mathrm{g}$ & 49 & 55 & 46 & 58 & 44 \\
\hline Potassium, $\mathrm{g}$ & 3.8 & 3.8 & 3.9 & 3.8 & 3.8 \\
\hline
\end{tabular}




\subsubsection{Children}

Table A7. Food intake in major food groups in 4 to 9 year-old children in Denmark, $n=298$

\begin{tabular}{|c|c|c|c|c|c|}
\hline & Scenario 1 & Scenario 2 & Scenario 3 & Scenario 4 & Scenario 5 \\
\hline Meat, total, g/d & 89 & 69 & 50 & - & - \\
\hline Red meat, $\mathrm{g} / \mathrm{d}^{1}$ & 39 & 39 & 39 & - & - \\
\hline White meat, $\mathrm{g} / \mathrm{d}^{1}$ & 11 & 31 & 11 & - & - \\
\hline Processed meat, $\mathrm{g} / \mathrm{d}^{2}$ & 40 & 0 & 0 & - & - \\
\hline Fish and other seafood, $\mathrm{g} / \mathrm{d}^{3}$ & 11 & 30 & 11 & - & - \\
\hline Egg, $g / d^{3}$ & 6 & 6 & 6 & - & - \\
\hline Potatoes, rice and pasta, $\mathrm{g} / \mathrm{d}^{3}$ & 91 & 91 & 97 & - & - \\
\hline Bread and cereals, $\mathrm{g} / \mathrm{d}^{3}$ & 181 & 181 & 193 & - & - \\
\hline Fat spread (on bread), $\mathrm{g} / \mathrm{d}^{3}$ & 19 & 19 & 20 & - & - \\
\hline Fat used in cooking, $\mathrm{g} / \mathrm{d}^{3,4}$ & 15 & 15 & 16 & - & - \\
\hline Fruit and berries, $\mathrm{g} / \mathrm{d}^{3}$ & 163 & 163 & 173 & - & - \\
\hline Juice, $g / d^{3}$ & 76 & 76 & 81 & - & - \\
\hline Vegetables, $\mathrm{g} / \mathrm{d}^{3}$ & 102 & 102 & 108 & - & - \\
\hline Milk and milk products, $\mathrm{g} / \mathrm{d}^{3}$ & 472 & 472 & 502 & - & - \\
\hline Cheese, $\mathrm{g} / \mathrm{d}^{3}$ & 17 & 17 & 18 & - & - \\
\hline Beverages, $\mathrm{g} / \mathrm{d}^{3}$ & 740 & 740 & 787 & - & - \\
\hline Water, tea and coffee, $\mathrm{g} / \mathrm{d}^{3}$ & 449 & 449 & 478 & - & - \\
\hline Soda and fruit nectar, $\mathrm{g} / \mathrm{d}^{3}$ & 290 & 290 & 308 & - & - \\
\hline Alcohol, beer and vine, $\mathrm{g} / \mathrm{d}^{3}$ & 1 & 1 & 1 & - & - \\
\hline Snacks, sweets, ice cream, $\mathrm{g} / \mathrm{d}^{3}$ & 91 & 91 & 97 & - & - \\
\hline Other, $g / d^{3}$ & 39 & 39 & 41 & - & - \\
\hline
\end{tabular}

${ }^{1}$ Cooked meat and minced meat, calculated $20 \%$ weight loss from raw meat

${ }^{2}$ Prepared processed meat products, not weight loss calculated

${ }^{3}$ Measured in raw weight

${ }^{4}$ Incl. gravy/sauce

Table A8. Macronutrient intake 4 to 9 year-old children in Denmark, $n=298$

\begin{tabular}{lrrrrr}
\hline & Scenario 1 & Scenario 2 & Scenario 3 & Scenario 4 & Scenario 5 \\
\hline Protein, E\% & 14.0 & 14.7 & 13.5 & - & \\
Fat, E\% & 34.0 & 32.7 & 31.8 & - & - \\
Saturated fat, E\% & 14.4 & 13.8 & 13.7 & - & - \\
Monounsaturated fat, E\% & 11.6 & 10.9 & 10.4 & - & - \\
Polyunsaturated fat, E\% & 4.9 & 4.9 & 4.6 & - & - \\
Carbohydrate, E\% & 52.0 & 52.6 & 54.7 & - & - \\
Added sugar, E\% & 12.1 & 12.4 & 12.9 & - & - \\
Dietary fibre, g/MJ & 2.2 & 2.2 & 2.3 & - & - \\
Alcohol, E\% & 0 & 0 & 0 & - & - \\
\hline
\end{tabular}

${ }^{1}$ Dietary fibre is included in the total carbohydrate (E\%). 
Table A9. Micronutrient intake 4 to 9 year-old children in Denmark, $n=298$

\begin{tabular}{|c|c|c|c|c|c|}
\hline & Scenario 1 & Scenario 2 & Scenario 3 & Scenario 4 & Scenario 5 \\
\hline Energy intake, MJ & 8.0 & 7.9 & 8.0 & - & - \\
\hline Dietary fibre, $\mathrm{g}$ & 17.42 & 17.38 & 18.37 & - & - \\
\hline Vitamin A, RE & 1079 & 754 & 764 & - & - \\
\hline Vitamin $D, \mu g$ & 2.3 & 3.6 & 2.2 & - & - \\
\hline Vitamin $E, \alpha-T E$ & 6.8 & 7.2 & 7.0 & - & - \\
\hline Thiamine, mg & 1.2 & 1.2 & 1.2 & - & - \\
\hline Riboflavin, mg & 1.7 & 1.6 & 1.6 & - & - \\
\hline Niacin, NE & 23 & 25 & 22 & - & - \\
\hline Vitamin $\mathrm{B}_{6}, \mathrm{mg}$ & 1.3 & 1.4 & 1.3 & - & - \\
\hline Folate, $\mu \mathrm{g}$ & 291 & 282 & 290 & - & - \\
\hline Vitamin $B_{12}, \mu g$ & 5.0 & 5.0 & 4.1 & - & - \\
\hline Vitamin C, mg & 108 & 102 & 108 & - & - \\
\hline Calcium, mg & 1,082 & 1,087 & 1,140 & - & - \\
\hline Phosphorus, mg & 1,312 & 1,310 & 1,308 & - & - \\
\hline Magnesium, mg & 267 & 269 & 275 & - & - \\
\hline Iron, mg & 8.0 & 7.5 & 7.6 & - & - \\
\hline Zinc, mg & 9 & 9 & 9 & - & - \\
\hline Copper, mg & 2.7 & 2.6 & 2.8 & - & - \\
\hline lodine $(\mu \mathrm{g})$ & 183 & 197 & 192 & - & - \\
\hline Selenium, $\mu \mathrm{g}$ & 36 & 41 & 34 & - & - \\
\hline Potassium, g & 2.6 & 2.7 & 2.7 & - & - \\
\hline
\end{tabular}

\subsubsection{Adolescents}

Table A10. Food intake in major food groups in 10 to17 year-old adolescents in Denmark, $\mathrm{n}=377$

\begin{tabular}{|c|c|c|c|c|c|}
\hline & Scenario 1 & Scenario 2 & Scenario 3 & Scenario 4 & Scenario 5 \\
\hline Meat, total, g/d & 104 & 88 & 72 & 81 & 58 \\
\hline Red meat, $\mathrm{g} / \mathrm{d}^{1}$ & 57 & 57 & 57 & 43 & 43 \\
\hline White meat, $\mathrm{g} / \mathrm{d}^{1}$ & 15 & 31 & 15 & 38 & 15 \\
\hline Processed meat, $\mathrm{g} / \mathrm{d}^{2}$ & 32 & 0 & 0 & 0 & 0 \\
\hline Fish and other seafood, $\mathrm{g} / \mathrm{d}^{3}$ & 9 & 25 & 10 & 32 & 10 \\
\hline Egg, $g / d^{3}$ & 5 & 5 & 5 & 5 & 5 \\
\hline Potatoes, rice and pasta, $\mathrm{g} / \mathrm{d}^{3}$ & 117 & 117 & 123 & 117 & 125 \\
\hline Bread and cereals, $\mathrm{g} / \mathrm{d}^{3}$ & 189 & 189 & 197 & 189 & 201 \\
\hline Fat spread (on bread), $g / d^{3}$ & 13 & 13 & 14 & 13 & 14 \\
\hline Fat used in cooking, $\mathrm{g} / \mathrm{d}^{3,4}$ & 20 & 20 & 21 & 20 & 21 \\
\hline Fruit and berries, $\mathrm{g} / \mathrm{d}^{3}$ & 150 & 150 & 157 & 150 & 159 \\
\hline Juice, $g / d^{3}$ & 99 & 99 & 104 & 99 & 105 \\
\hline Vegetables, $\mathrm{g} / \mathrm{d}^{3}$ & 99 & 99 & 104 & 99 & 105 \\
\hline Milk and milk products, $\mathrm{g} / \mathrm{d}^{3}$ & 396 & 396 & 415 & 396 & 422 \\
\hline Cheese, $\mathrm{g} / \mathrm{d}^{3}$ & 24 & 24 & 25 & 24 & 26 \\
\hline Beverages, $\mathrm{g} / \mathrm{d}^{3}$ & 1,032 & 1,032 & 1,079 & 1,032 & 1,097 \\
\hline Water, tea and coffee, $\mathrm{g} / \mathrm{d}^{3}$ & 638 & 638 & 668 & 638 & 679 \\
\hline Soda and fruit nectar, $\mathrm{g} / \mathrm{d}^{3}$ & 355 & 355 & 371 & 355 & 377 \\
\hline Alcohol, beer and vine, $\mathrm{g} / \mathrm{d}^{3}$ & 39 & 39 & 41 & 39 & 41 \\
\hline Snacks, sweets, ice cream, $\mathrm{g} / \mathrm{d}^{3}$ & 92 & 92 & 96 & 92 & 98 \\
\hline Other, $g / d^{3}$ & 56 & 56 & 58 & 56 & 59 \\
\hline
\end{tabular}

${ }^{1}$ Cooked meat and minced meat, calculated $20 \%$ weight loss from raw meat

${ }^{2}$ Prepared processed meat products, not weight loss calculated

${ }^{3}$ Measured in raw weight

${ }^{4}$ Incl. gravy/sauce 
Table A11. Macronutrient intake 10 to 17 year-old adolescents in Denmark, $n=377$

\begin{tabular}{lrrrrr}
\hline & Scenario 1 & Scenario 2 & Scenario 3 & Scenario 4 & Scenario 5 \\
\hline Protein, E\% & 14.4 & 14.9 & 14.0 & 15.0 & 13.6 \\
Fat, E\% & 32.7 & 31.8 & 31.2 & 31.8 & 30.8 \\
Saturated fat, E\% & 13.8 & 13.5 & 13.4 & 13.3 & 13.2 \\
Monounsaturated fat, E\% & 11.3 & 10.8 & 10.5 & 10.7 & 10.3 \\
Polyunsaturated fat, E\% & 4.7 & 4.8 & 4.6 & 4.9 & 4.6 \\
Carbohydrate, E\% & 52.2 & 52.5 & 54.1 & 52.5 & 54.7 \\
Added sugar, E\% & 12.4 & 12.5 & 12.9 & 12.6 & 13.1 \\
$\quad$ Dietary fibre, g/MJ & 2.1 & 2.1 & 2.1 & 2.1 & 2.2 \\
Alcohol, E\% & 0.7 & 0.7 & 0.8 & 0.7 & 0.8 \\
\hline
\end{tabular}

1 Dietary fibre is included in the total carbohydrate (E\%).

Table A12. Micronutrient intake 10 to 17 year-old adolescents in Denmark, $n=377$

\begin{tabular}{|c|c|c|c|c|c|}
\hline & Scenario 1 & Scenario 2 & Scenario 3 & Scenario 4 & Scenario 5 \\
\hline Energy intake, $\mathrm{MJ}$ & 8.5 & 8.4 & 8.5 & 8.4 & 8.5 \\
\hline Dietary fibre, $\mathrm{g}$ & 17.7 & 17.6 & 18.3 & 17.5 & 18.5 \\
\hline Vitamin A, RE & 935 & 712 & 715 & 717 & 718 \\
\hline Vitamin $D, \mu g$ & 2.4 & 3.7 & 2.3 & 4.3 & 2.3 \\
\hline Vitamin E, $\alpha$-TE & 7.0 & 7.3 & 7.2 & 7.5 & 7.2 \\
\hline Thiamine, $\mathrm{mg}$ & 1.3 & 1.3 & 1.3 & 1.3 & 1.3 \\
\hline Riboflavin, mg & 1.6 & 1.6 & 1.6 & 1.6 & 1.6 \\
\hline Niacin, NE & 27 & 28 & 26 & 29 & 25 \\
\hline Vitamin $B_{6}, \mathrm{mg}$ & 1.5 & 1.5 & 1.4 & 1.5 & 1.4 \\
\hline Folate, $\mu \mathrm{g}$ & 311 & 305 & 311 & 306 & 313 \\
\hline Vitamin $B_{12}, \mu g$ & 4.6 & 4.6 & 3.9 & 4.8 & 3.8 \\
\hline Vitamin C, mg & 116 & 112 & 116 & 112 & 118 \\
\hline Calcium, mg & 1,100 & 1,104 & 1,142 & 1,101 & 1,152 \\
\hline Phosphorus, mg & 1,358 & 1,358 & 1,349 & 1,356 & 1,341 \\
\hline Magnesium, mg & 284 & 287 & 290 & 287 & 291 \\
\hline Iron, mg & 8.7 & 8.3 & 8.4 & 8.2 & 8.3 \\
\hline Zinc, mg & 10 & 10 & 10 & 10 & 9 \\
\hline Copper, mg & 3.2 & 3.2 & 3.3 & 3.2 & 3.3 \\
\hline lodine $(\mu \mathrm{g})$ & 183 & 193 & 189 & 196 & 190 \\
\hline Selenium, $\mu \mathrm{g}$ & 38 & 43 & 36 & 45 & 35 \\
\hline Potassium, $\mathrm{g}$ & 2.8 & 2.8 & 2.8 & 2.8 & 2.8 \\
\hline
\end{tabular}




\subsection{Finland}

\subsubsection{Women}

Table A13. Food intake in major food groups in $\mathbf{2 5}$ to $\mathbf{7 4}$ year-old women in Finland, $\mathbf{n = 1 0 8 0}$

\begin{tabular}{|c|c|c|c|c|c|}
\hline & Scenario 1 & Scenario 2 & Scenario 3 & Scenario 4 & Scenario 5 \\
\hline Meat, total, g/d & 75.7 & 62.1 & 48.4 & 62.1 & 48.4 \\
\hline Red meat, $\mathrm{g} / \mathrm{d}^{1,13}$ & 30.2 & 30.2 & 30.2 & 30.2 & 30.2 \\
\hline White meat, $\mathrm{g} / \mathrm{d}^{2,13}$ & 18.3 & 31.9 & 18.3 & 31.9 & 18.3 \\
\hline Processed meat, $\mathrm{g} / \mathrm{d}^{3,14}$ & 27.2 & 0.0 & 0.0 & 0.0 & 0.0 \\
\hline Fish, $g / d^{15}$ & 23.3 & 36.9 & 23.3 & 36.9 & 23.3 \\
\hline Egg, $g / d^{15}$ & 13.1 & 13.1 & 13.1 & 13.1 & 13.1 \\
\hline Potatoes, rice, pasta, $\mathrm{g} / \mathrm{d}^{4,15}$ & 85.1 & 85.1 & 90.5 & 85.1 & 90.5 \\
\hline Bread and cereals, $\mathrm{g} / \mathrm{d}^{5,15}$ & 120.1 & 120.1 & 127.8 & 120.1 & 127.8 \\
\hline Fat spread (on bread), $g / d^{6,15}$ & 19.8 & 19.8 & 19.8 & 19.8 & 19.8 \\
\hline Fat used in cooking, $\mathrm{g} / \mathrm{d}^{7,15}$ & 12.6 & 12.6 & 12.6 & 12.6 & 12.6 \\
\hline Fruit (excl. juice), $g / d^{8,15}$ & 195.0 & 195.0 & 195.0 & 195.0 & 195.0 \\
\hline Juice, $g / d^{15}$ & 41.9 & 41.9 & 41.9 & 41.9 & 41.9 \\
\hline Vegetables ${ }^{9,15}$ & 159.9 & 159.9 & 170.1 & 159.9 & 170.1 \\
\hline Milk and milk products, $\mathrm{g} / \mathrm{d}^{10,15}$ & 380.4 & 380.4 & 404.7 & 380.4 & 404.7 \\
\hline Cheese, $\mathrm{g} / \mathrm{d}^{15}$ & 31.8 & 31.8 & 31.8 & 31.8 & 31.8 \\
\hline Beverages, $\mathrm{g} / \mathrm{d}^{15}$ & $1,745.4$ & $1,745.4$ & $1,745.4$ & $1,745.4$ & $1,745.4$ \\
\hline Water, tea and coffee, $\mathrm{g} / \mathrm{d}^{15}$ & $1,576.2$ & $1,576.2$ & $1,576.2$ & $1,576.2$ & $1,576.2$ \\
\hline Soda and fruit nectar, $\mathrm{g} / \mathrm{d}^{15}$ & 116.6 & 116.6 & 116.6 & 116.6 & 116.6 \\
\hline Alcohol, beer and vine, $\mathrm{g} / \mathrm{d} 1^{5}$ & 52.6 & 52.6 & 52.6 & 52.6 & 52.6 \\
\hline Savoury, sweets, $\mathrm{g} / \mathrm{d}^{11,15}$ & 14.7 & 14.7 & 14.7 & 14.7 & 14.7 \\
\hline Other, $\mathrm{g} / \mathrm{d}^{12,15}$ & 34.2 & 34.2 & 34.2 & 34.2 & 34.2 \\
\hline
\end{tabular}

${ }^{1}$ Beef, Pork, Lamb

2 Poultry

${ }^{3}$ Sausage, meat products (cold cuts)

${ }^{4}$ Potatoes, potato products, rice, pasta

${ }^{5}$ Wheat, rye, oat, barley, other cereal, hard bread, biscuit, starch

${ }^{6}$ butter, butter-oil mixes and margarine

${ }^{7}$ oil, animal fat (suet, lard), other fat (salad dressings, mayonnaise, fish oil), cooking fat and fat us ed by industry

${ }^{8}$ Apple fruit, citrus, other fruit, canned fruit, berries

${ }^{9}$ Leaf vegetables, fruit vegetables, cabbage, onion, root, mushroom, canned vegetables, pulse, nuts and seeds, soy products

${ }^{10}$ Milk, sour milk products, cream, ice cream, other milk (powdered milk, milk protein)

${ }^{11}$ Sweets, chocolate, snacks

12 Offal, game, sugar and syrup, other sugar prod, herbs, flavourings and spices, spice sauces, salt, sweeteners, other miscellaneous, industrial meals, baby foods, formula milk, vitamin/mineral /fatty acid/fibre supplements, enzymes, herb suppl, homeopathic suppl, yeast, probiotic and prebiotic etc.

${ }^{13}$ Cooked meat and minced meat, calculated $20 \%$ weight loss from raw meat

${ }^{14}$ Prepared processed meat products, not weight loss calculated

${ }^{15}$ Partially cooked fish, calculated $10 \%$ weight loss from raw fish. 
Table A14. Macronutrient intake 25 to 74 year-old women in Finland, $\mathbf{n = 1 0 8 0}$

\begin{tabular}{lrrrrr}
\hline & Scenario 1 & Scenario 2 & Scenario 3 & Scenario 4 & Scenario 5 \\
\hline Protein, E\% & 17.3 & 17.8 & 16.7 & 17.8 & 16.7 \\
Fat, E\% & 31.0 & 30.7 & 29.7 & 30.7 & 29.7 \\
Saturated fat, E\% & 11.2 & 10.8 & 10.8 & 10.8 & 10.8 \\
Monounsaturated fat, E\% & 10.2 & 10.0 & 9.6 & 10.0 & 9.6 \\
Polyunsaturated fat, E\% & 5.3 & 5.4 & 5.1 & 5.4 & 5.1 \\
Carbohydrate, E\% & 50.5 & 50.3 & 52.4 & 50.3 & 52.4 \\
Added sugar, E\% & 10.2 & 10.3 & 10.4 & 10.3 & 10.4 \\
$\quad$ Dietary fibre, g/MJ & 3.3 & 3.1 & 3.3 & 3.2 & 3.3 \\
Alcohol, E\% & 1.3 & 1.3 & 1.3 & 1.3 & 1.3 \\
\hline
\end{tabular}

${ }^{1}$ Dietary fibre is included in the total carbohydrate (E\%).

Table A15. Micronutrient intake 25 to 74 year-old women in Finland, $\mathbf{n = 1 0 8 0}$

\begin{tabular}{|c|c|c|c|c|c|}
\hline & Scenario 1 & Scenario 2 & Scenario 3 & Scenario 4 & Scenario 5 \\
\hline Energy intake, MJ & 6.6 & 6.6 & 6.6 & 6.6 & 6.6 \\
\hline Dietary fibre, $g$ & 20.8 & 20.8 & 21.7 & 20.8 & 21.7 \\
\hline Vitamin A, RE & 707 & 714.1 & 723.2 & 714.1 & 723.2 \\
\hline Vitamin $D, \mu g$ & 5.5 & 6.7 & 5.5 & 6.7 & 5.5 \\
\hline Vitamin $E, \alpha-T E$ & 8.0 & 8.3 & 8.1 & 8.3 & 8.1 \\
\hline Thiamine, mg & 1.1 & 1.0 & 1.1 & 1.0 & 1.1 \\
\hline Riboflavin, mg & 1.6 & 1.6 & 1.6 & 1.6 & 1.6 \\
\hline Niacin, NE & 25.7 & 26.7 & 24.6 & 26.7 & 24.6 \\
\hline Vitamin $\mathrm{B}_{6}, \mathrm{mg}$ & 1.6 & 1.6 & 1.5 & 1.6 & 1.5 \\
\hline Folate, $\mu \mathrm{g}$ & 222 & 225.0 & 230.2 & 225.0 & 230.2 \\
\hline Vitamin $\mathrm{B}_{12}, \mu \mathrm{g}$ & 4.7 & 5.4 & 4.6 & 5.4 & 4.6 \\
\hline Vitamin C, mg & 113.5 & 113.5 & 116.5 & 113.5 & 116.5 \\
\hline Calcium, mg & 984 & 995.7 & $1,015.9$ & 995.7 & $1,015.9$ \\
\hline Phosphorus, mg & 1,349 & $1,364.8$ & $1,354.6$ & $1,364.8$ & $1,354.6$ \\
\hline Magnesium, mg & 338 & 340.3 & 345.4 & 340.3 & 345.4 \\
\hline Iron, mg & 10.2 & 10.2 & 10.4 & 10.2 & 10.4 \\
\hline Zinc, mg & 9.9 & 9.9 & 9.8 & 9.9 & 9.8 \\
\hline Copper, mg & 1.2 & 1.2 & 1.2 & 1.2 & 1.2 \\
\hline lodine $(\mu \mathrm{g})$ & 191 & 199.1 & 194.8 & 199.1 & 194.8 \\
\hline Selenium, $\mu \mathrm{g}$ & 53.3 & 54.6 & 50.3 & 54.6 & 50.3 \\
\hline Potassium, g & 3.4 & 3.4 & 3.5 & 3.4 & 3.5 \\
\hline
\end{tabular}




\subsubsection{Men}

Table A16. Food intake in major food groups in $\mathbf{2 5}$ to $\mathbf{7 4}$ year-old men in Finland, $\mathbf{n = 9 5 8}$

\begin{tabular}{|c|c|c|c|c|c|}
\hline & Scenario 1 & Scenario 2 & Scenario 3 & Scenario 4 & Scenario 5 \\
\hline Meat, total, g/d & 127.7 & 99.2 & 70.7 & 96.9 & 66.0 \\
\hline Red meat, $\mathrm{g} / \mathrm{d}^{1,13}$ & 47.7 & 47.7 & 47.7 & 43.0 & 43.0 \\
\hline White meat, $\mathrm{g} / \mathrm{d}^{2,13}$ & 23.0 & 51.5 & 23.0 & 53.9 & 23.0 \\
\hline Processed meat, $\mathrm{g} / \mathrm{d}^{3,14}$ & 57.0 & 0.0 & 0.0 & 0.0 & 0.0 \\
\hline Fish, $g / d^{15}$ & 27.7 & 56.2 & 27.7 & 58.5 & 27.7 \\
\hline Egg, $g / d^{15}$ & 18.7 & 18.7 & 18.7 & 18.7 & 18.7 \\
\hline Potatoes, rice, pasta, $\mathrm{g} / \mathrm{d}^{4,15}$ & 121.0 & 121.0 & 134.8 & 121.0 & 136.0 \\
\hline Bread and cereals, $\mathrm{g} / \mathrm{d}^{5,15}$ & 161.3 & 161.3 & 179.6 & 161.3 & 181.3 \\
\hline Fat spread (on bread), $g / d^{6,15}$ & 31.1 & 31.1 & 31.1 & 31.1 & 31.1 \\
\hline Fat used in cooking, $\mathrm{g} / \mathrm{d}^{7,15}$ & 16.5 & 16.5 & 16.5 & 16.5 & 16.5 \\
\hline Fruit (excl. juice), $\mathrm{g} / \mathrm{d}^{8,15}$ & 149.6 & 149.6 & 149.6 & 149.6 & 149.6 \\
\hline Juice, $g / d^{15}$ & 50.3 & 50.3 & 50.3 & 50.3 & 50.3 \\
\hline Vegetables $^{9,15}$ & 134.4 & 134.4 & 149.6 & 134.4 & 151.0 \\
\hline Milk and milk products, $\mathrm{g} / \mathrm{d}^{10,15}$ & 462.1 & 462.1 & 514.3 & 462.1 & 519.8 \\
\hline Cheese, $\mathrm{g} / \mathrm{d}^{15}$ & 36.1 & 36.1 & 36.1 & 36.1 & 36.1 \\
\hline Beverages, $\mathrm{g} / \mathrm{d}^{15}$ & $1,836.1$ & $1,836.1$ & $1,836.1$ & $1,836.1$ & $1,836.1$ \\
\hline Water, tea and coffee, $\mathrm{g} / \mathrm{d}^{15}$ & $1,452.6$ & $1,452.6$ & $1,452.6$ & $1,452.6$ & $1,452.6$ \\
\hline Soda and fruit nectar, $\mathrm{g} / \mathrm{d}^{15}$ & 200.7 & 200.7 & 200.7 & 200.7 & 200.7 \\
\hline Alcohol, beer and vine, $\mathrm{g} / \mathrm{d} 1^{5}$ & 182.8 & 182.8 & 182.8 & 182.8 & 182.8 \\
\hline Savoury, sweets, $\mathrm{g} / \mathrm{d}^{11,15}$ & 11.0 & 11.0 & 11.0 & 11.0 & 11.0 \\
\hline Other, $\mathrm{g} / \mathrm{d}^{12,15}$ & 51.4 & 51.4 & 51.4 & 51.4 & 51.4 \\
\hline
\end{tabular}

${ }^{1}$ Beef, Pork, Lamb

${ }^{2}$ Poultry

${ }^{3}$ Sausage, meat products (cold cuts)

${ }^{4}$ Potatoes, potato products, rice, pasta

${ }^{5}$ Wheat, rye, oat, barley, other cereal, hard bread, biscuit, starch

${ }^{6}$ butter, butter-oil mixes and margarine

${ }^{7}$ oil, animal fat (suet, lard), other fat (salad dressings, mayonnaise, fish oil), cooking fat and fat used by industry

${ }^{8}$ Apple fruit, citrus, other fruit, canned fruit, berries

${ }^{9}$ Leaf vegetables, fruit vegetables, cabbage, onion, root, mushroom, canned vegetables, pulse, nuts and seeds, soy products

${ }^{10}$ Milk, sour milk products, cream, ice cream, other milk (powdered milk, milk protein)

${ }^{11}$ Sweets, chocolate, snacks

${ }^{12}$ Offal, game, sugar and syrup, other sugar prod, herbs, flavourings and spices, spice sauces, salt, sweeteners, other miscellaneous, industrial meals, baby foods, formula milk, vitamin/mineral /fatty acid/fibre supplements, enzymes, herb suppl, homeopathic suppl, yeast, probiotic and prebiotic etc. ${ }^{13}$ Cooked meat and minced meat, calculated $20 \%$ weight loss from raw meat

${ }^{14}$ Prepared processed meat products, not weight loss calculated

${ }^{15}$ Partially cooked fish, calculated $10 \%$ weight loss from raw fish. 
Table A17. Macronutrient intake 25 to 74 year-old men in Finland, $\mathbf{n}=\mathbf{9 5 8}$

\begin{tabular}{lrrrrr}
\hline & Scenario 1 & Scenario 2 & Scenario 3 & Scenario 4 & Scenario 5 \\
\hline Protein, E\% & 16.9 & 17.9 & 16.1 & 17.9 & 16.0 \\
Fat, E\% & 32.7 & 31.9 & 30.2 & 31.8 & 30.0 \\
Saturated fat, E\% & 12.0 & 11.3 & 11.1 & 11.2 & 11.0 \\
Monounsaturated fat, E\% & 11.1 & 10.8 & 10.0 & 10.7 & 9.9 \\
Polyunsaturated fat, E\% & 5.5 & 5.6 & 5.2 & 5.7 & 5.2 \\
Carbohydrate, E\% & 47.7 & 47.5 & 50.9 & 47.6 & 51.3 \\
Added sugar, E\% & 9.6 & 9.6 & 9.7 & 9.7 & 9.8 \\
Dietary fibre, g/MJ ${ }^{1}$ & 2.8 & 2.7 & 3.0 & 2.7 & 3.0 \\
Alcohol, E\% & 2.7 & 2.7 & 2.7 & 2.7 & 2.7 \\
\hline
\end{tabular}

${ }^{1}$ Dietary fibre is included in the total carbohydrate (E\%).

Table A18. Micronutrient intake 25 to 74 year-old men in Finland, $\mathbf{n = 9 5 8}$

\begin{tabular}{|c|c|c|c|c|c|}
\hline & Scenario 1 & Scenario 2 & Scenario 3 & Scenario 4 & Scenario 5 \\
\hline Energy intake, MJ & 8.9 & 8.9 & 8.9 & 8.9 & 8.9 \\
\hline Dietary fibre, $\mathrm{g}$ & 23.8 & 23.8 & 25.98 & 23.8 & 26.2 \\
\hline Vitamin A, RE & 933 & 949.2 & 958 & 950.4 & 960.5 \\
\hline Vitamin $D, \mu g$ & 7.5 & 10.2 & 7.6 & 10.4 & 7.6 \\
\hline Vitamin $E, \alpha-T E$ & 9.9 & 10.6 & 10.0 & 10.6 & 10.0 \\
\hline Thiamine, mg & 1.4 & 1.3 & 1.3 & 1.3 & 1.3 \\
\hline Riboflavin, mg & 2.0 & 2.0 & 2.0 & 2.0 & 2.0 \\
\hline Niacin, NE & 34.1 & 36.7 & 32.5 & 36.7 & 32.2 \\
\hline Vitamin $\mathrm{B}_{6}, \mathrm{mg}$ & 2.1 & 2.2 & 2.0 & 2.2 & 2.0 \\
\hline Folate, $\mu \mathrm{g}$ & 263 & 269.4 & 280 & 270.0 & 281.5 \\
\hline Vitamin $B_{12}, \mu g$ & 6.6 & 8.0 & 6.5 & 8.1 & 6.4 \\
\hline Vitamin C, mg & 96.5 & 96.5 & 101 & 96.5 & 101.7 \\
\hline Calcium, mg & 1,162 & $1,188.0$ & 1,229 & $1,190.3$ & $1,235.8$ \\
\hline Phosphorus, mg & 1,738 & $1,778.9$ & 1,764 & $1,779.7$ & $1,765.5$ \\
\hline Magnesium, mg & 417 & 422.0 & 434 & 422.1 & 435.9 \\
\hline Iron, mg & 13.3 & 13.4 & 13.7 & 13.3 & 13.7 \\
\hline Zinc, mg & 13.3 & 13.3 & 13.2 & 13.1 & 13.1 \\
\hline Copper, mg & 1.5 & 1.5 & 1.6 & 1.5 & 1.6 \\
\hline lodine $(\mu \mathrm{g})$ & 247 & 263.3 & 255 & 264.7 & 256.3 \\
\hline Selenium, $\mu \mathrm{g}$ & 71.5 & 74.7 & 65.9 & 74.6 & 65.2 \\
\hline Potassium, g & 4.1 & 4.2 & 4.2 & 4.2 & 4.2 \\
\hline
\end{tabular}




\subsubsection{Adolescents}

Table A19. Food intake in major food groups in 13 to 14 year-old adolescents in Finland, $\mathbf{n = 3 0 6}$

\begin{tabular}{|c|c|c|c|c|c|}
\hline & Scenario 1 & Scenario 2 & Scenario 3 & Scenario 4 & Scenario 5 \\
\hline Meat, total, g/d & 94.8 & 80.8 & 66.9 & 84.3 & 66.0 \\
\hline Red meat, $\mathrm{g} / \mathrm{d}^{1,13}$ & 44.2 & 44.2 & 44.2 & 39.2 & 39.6 \\
\hline White meat, $\mathrm{g} / \mathrm{d}^{2,13}$ & 22.6 & 36.6 & 22.6 & 39.1 & 26.4 \\
\hline Processed meat, $\mathrm{g} / \mathrm{d}^{3,14}$ & 27.9 & 0.0 & 0.0 & 0.0 & 0.0 \\
\hline Fish, $g / d^{15}$ & 14.9 & 28.9 & 14.9 & 31.4 & 15.1 \\
\hline Egg, $g / d^{15}$ & 10.6 & 10.6 & 10.6 & 10.6 & 10.7 \\
\hline Potatoes, rice, pasta, $\mathrm{g} / \mathrm{d}^{4,15}$ & 126.0 & 126.0 & 134.0 & 126.0 & 138.4 \\
\hline Bread and cereals, $\mathrm{g} / \mathrm{d}^{5,15}$ & 110.5 & 110.5 & 117.4 & 110.5 & 120.2 \\
\hline Fat spread (on bread), $g / d^{6,15}$ & 20.8 & 20.8 & 20.8 & 20.8 & 21.0 \\
\hline Fat used in cooking, $\mathrm{g} / \mathrm{d}^{7,15}$ & 12.5 & 12.5 & 12.5 & 12.5 & 12.6 \\
\hline Fruit (excl. juice), $g / d^{8,15}$ & 111.3 & 111.3 & 111.3 & 111.3 & 109.1 \\
\hline Juice, $g / d^{15}$ & 94.4 & 94.4 & 94.4 & 94.4 & 95.0 \\
\hline Vegetables $^{9,15}$ & 129.4 & 129.4 & 137.2 & 129.4 & 137.5 \\
\hline Milk and milk products, $\mathrm{g} / \mathrm{d}^{10,15}$ & 599.2 & 599.2 & 636.8 & 599.2 & 658.4 \\
\hline Cheese, $\mathrm{g} / \mathrm{d}^{15}$ & 22.0 & 22.0 & 22.0 & 22.0 & 22.1 \\
\hline Beverages, $\mathrm{g} / \mathrm{d}^{15}$ & 861.3 & 861.3 & 861.3 & 861.3 & 861.3 \\
\hline Water, tea and coffee, $\mathrm{g} / \mathrm{d}^{15}$ & 595.3 & 595.3 & 595.3 & 595.3 & 580.2 \\
\hline Soda and fruit nectar, $\mathrm{g} / \mathrm{d}^{15}$ & 264.3 & 264.3 & 264.3 & 264.3 & 273.4 \\
\hline Alcohol, beer and vine, $\mathrm{g} / \mathrm{d} 1^{5}$ & 1.8 & 1.8 & 1.8 & 1.8 & 1.8 \\
\hline Savoury, sweets, $\mathrm{g} / \mathrm{d}^{11,15}$ & 24.8 & 24.8 & 24.8 & 24.8 & 25.1 \\
\hline Other, $\mathrm{g} / \mathrm{d}^{12,15}$ & 30.0 & 30.0 & 30.0 & 30.0 & 30.1 \\
\hline
\end{tabular}

${ }^{1}$ Beef, Pork, Lamb

${ }^{2}$ Poultry

${ }^{3}$ Sausage, meat products (cold cuts)

${ }^{4}$ Potatoes, potato products, rice, pasta

${ }^{5}$ Wheat, rye, oat, barley, other cereal, hard bread, biscuit, starch

${ }^{6}$ butter, butter-oil mixes and margarine

${ }^{7}$ oil, animal fat (suet, lard), other fat (salad dressings, mayonnaise, fish oil), cooking fat and fat used by industry

${ }^{8}$ Apple fruit, citrus, other fruit, canned fruit, berries

${ }^{9}$ Leaf vegetables, fruit vegetables, cabbage, onion, root, mushroom, canned vegetables, pulse, nuts and seeds, soy products

${ }^{10}$ Milk, sour milk products, cream, ice cream, other milk (powdered milk, milk protein)

${ }^{11}$ Sweets, chocolate, snacks

12 Offal, game, sugar and syrup, other sugar prod, herbs, flavourings and spices, spice sauces, salt, sweeteners, other miscellaneous, industrial meals, baby foods, formula milk, vitamin/mineral /fatty acid/fibre supplements, enzymes, herb suppl, homeopathic suppl, yeast, probiotic and prebiotic etc. ${ }^{13}$ Cooked meat and minced meat, calculated $20 \%$ weight loss from raw meat

${ }^{14}$ Prepared processed meat products, not weight loss calculated

${ }^{15}$ Partially cooked fish, calculated $10 \%$ weight loss from raw fish. 
Table A20. Macronutrient intake 13 to 14 year-old adolescents in Finland, n=306

\begin{tabular}{lrrrrr}
\hline & Scenario 1 & Scenario 2 & Scenario 3 & Scenario 4 & Scenario 5 \\
\hline Protein, E\% & 16.3 & 16.9 & 15.8 & 16.9 & 15.7 \\
Fat, E\% & 29.9 & 29.3 & 28.4 & 29.2 & 28.1 \\
Saturated fat, E\% & 11.0 & 10.6 & 10.5 & 10.5 & 10.4 \\
Monounsaturated fat, E\% & 10.3 & 10.0 & 9.6 & 10.0 & 9.5 \\
Polyunsaturated fat, E\% & 5.0 & 5.0 & 4.8 & 5.0 & 4.7 \\
Carbohydrate, E\% & 53.7 & 53.7 & 55.6 & 53.8 & 56.1 \\
Added sugar, E\% & 12.6 & 12.7 & 12.8 & 12.7 & 12.8 \\
$\quad$ Dietary fibre, g/MJ & 2.3 & 2.3 & 2.4 & 2.3 & 2.4 \\
Alcohol, E\% & 0.0 & 0.0 & 0.0 & 0.0 & 0.0
\end{tabular}

1 Dietary fibre is included in the total carbohydrate (E\%).

Table A21. Micronutrient intake 13 to 14 year-old adolescents in Finland, n=306

\begin{tabular}{|c|c|c|c|c|c|}
\hline & Scenario 1 & Scenario 2 & Scenario 3 & Scenario 4 & Scenario 5 \\
\hline Energy intake, MJ & 7.4 & 7.4 & 7.4 & 7.4 & 7.4 \\
\hline Dietary fibre, $\mathrm{g}$ & 16.7 & 16.7 & 17.6 & 16.7 & 17.8 \\
\hline Vitamin A, RE & 531.2 & 535.6 & 542.9 & 536.2 & 545.3 \\
\hline Vitamin D, $\mu \mathrm{g}$ & 5.7 & 6.7 & 5.8 & 6.9 & 5.8 \\
\hline Vitamin E, $\alpha$-TE & 7.5 & 7.8 & 7.6 & 7.9 & 7.6 \\
\hline Thiamine, mg & 1.2 & 1.1 & 1.1 & 1.1 & 1.1 \\
\hline Riboflavin, mg & 1.9 & 1.9 & 2.0 & 1.9 & 2.0 \\
\hline Niacin, NE & 24.7 & 25.9 & 23.9 & 26.0 & 23.5 \\
\hline Vitamin B6, mg & 1.8 & 1.9 & 1.8 & 1.9 & 1.8 \\
\hline Folate, $\mu \mathrm{g}$ & 195.8 & 198.8 & 203.6 & 199.3 & 205.3 \\
\hline Vitamin B12, $\mu \mathrm{g}$ & 4.5 & 5.1 & 4.5 & 5.2 & 4.5 \\
\hline Vitamin C, mg & 90.4 & 90.4 & 93.0 & 90.4 & 93.6 \\
\hline Calcium, mg & $1,139.1$ & $1,148.6$ & $1,185.9$ & $1,150.3$ & $1,198.0$ \\
\hline Phosphorus, mg & $1,418.8$ & $1,438.5$ & $1,436.5$ & $1,439.2$ & $1,439.4$ \\
\hline Magnesium, mg & 298.9 & 301.0 & 306.8 & 301.1 & 308.8 \\
\hline Iron, mg & 9.6 & 9.6 & 9.7 & 9.5 & 9.6 \\
\hline Zinc, mg & 10.6 & 10.5 & 10.5 & 10.4 & 10.4 \\
\hline Copper, mg & 1.1 & 1.1 & 1.2 & 1.1 & 1.2 \\
\hline lodine $(\mu \mathrm{g})$ & 215.8 & 225.0 & 221.6 & 226.7 & 223.0 \\
\hline Selenium, $\mu \mathrm{g}$ & 57.8 & 59.5 & 55.4 & 59.4 & 54.5 \\
\hline Potassium, g & 3.3 & 3.3 & 3.3 & 3.3 & 3.4 \\
\hline
\end{tabular}




\subsection{Norway}

\subsubsection{Women}

Table A22. Food intake in major food groups in 18 to 70 year-old women in Norway, $n=925$

\begin{tabular}{|c|c|c|c|c|c|}
\hline & Scenario 1 & Scenario 2 & Scenario 3 & Scenario 4 & Scenario 5 \\
\hline Meat, total, g/d & 99.8 & 82.0 & 64.2 & 81.3 & 62.8 \\
\hline Red meat, $\mathrm{g} / \mathrm{d}^{1}$ & 44.4 & 44.4 & 44.4 & 43.0 & 43.0 \\
\hline White meat, $\mathrm{g} / \mathrm{d}^{1}$ & 19.8 & 37.6 & 19.8 & 38.3 & 19.8 \\
\hline Processed meat, $\mathrm{g} / \mathrm{d}^{2}$ & 35.6 & 0.0 & 0.0 & 0.0 & 0.0 \\
\hline Fish and other seafood, $\mathrm{g} / \mathrm{d}^{3}$ & 56.1 & 73.9 & 58.6 & 74.6 & 60.4 \\
\hline Egg, $g / d^{3}$ & 22.8 & 22.8 & 23.8 & 22.8 & 24.5 \\
\hline Potatoes, rice and pasta, $\mathrm{g} / \mathrm{d}^{3}$ & 68.7 & 68.7 & 71.8 & 68.7 & 74.0 \\
\hline Bread and cereals, $\mathrm{g} / \mathrm{d}^{3}$ & 160.6 & 160.6 & 167.8 & 160.6 & 172.9 \\
\hline Fat spread (on bread), $\mathrm{g} / \mathrm{d}^{3}$ & 19.8 & 19.8 & 20.7 & 19.8 & 21.3 \\
\hline Fat used in cooking, $\mathrm{g} / \mathrm{d}^{3}$ & 10.4 & 10.4 & 10.9 & 10.4 & 11.2 \\
\hline Fruit and berries (excl. juice), $\mathrm{g} / \mathrm{d}^{3}$ & 169.0 & 169.0 & 176.6 & 169.0 & 181.9 \\
\hline Juice, $g / d^{3}$ & 100.0 & 100.0 & 104.5 & 100.0 & 107.7 \\
\hline Vegetables, $\mathrm{g} / \mathrm{d}^{3}$ & 155.1 & 155.1 & 162.1 & 155.1 & 167.0 \\
\hline Milk and milk products, $\mathrm{g} / \mathrm{d}^{3}$ & 261.6 & 261.6 & 273.4 & 261.6 & 281.6 \\
\hline Cheese, $\mathrm{g} / \mathrm{d}^{3}$ & 42.0 & 42.0 & 43.9 & 42.0 & 45.2 \\
\hline Beverages, $\mathrm{g} / \mathrm{d}^{3}$ & $2,132.3$ & $2,132.3$ & $2,228.2$ & $2,132.3$ & $2,295.4$ \\
\hline Water, tea and coffee, $\mathrm{g} / \mathrm{d}^{3}$ & $1,841.9$ & $1,841.9$ & $1,924.7$ & $1,841.9$ & $1,982.8$ \\
\hline Soda and fruit nectar, $\mathrm{g} / \mathrm{d}^{3}$ & 201.5 & 201.5 & 210.6 & 201.5 & 216.9 \\
\hline Alcohol, beer and vine, $\mathrm{g} / \mathrm{d}^{3}$ & 88.9 & 88.9 & 92.9 & 88.9 & 95.7 \\
\hline Snacks, sweets, ice cream, $\mathrm{g} / \mathrm{d}^{3}$ & 83.3 & 83.3 & 87.0 & 83.3 & 89.7 \\
\hline Other, $\mathrm{g} / \mathrm{d}^{3}$ & 91.6 & 91.6 & 95.7 & 91.6 & 98.6 \\
\hline
\end{tabular}

${ }^{1}$ Cooked meat and minced meat, calculated $20 \%$ weight loss from raw meat

${ }^{2}$ Prepared processed meat products, not weight loss calculated

${ }^{3}$ Measured in raw weight

Table A23. Macronutrient intake 18 to 70 year-old women in Norway, $n=925$

\begin{tabular}{lrrrrr}
\hline & Scenario 1 & Scenario 2 & Scenario 3 & Scenario 4 & Scenario 5 \\
\hline Protein, E\% & 17.2 & 18.0 & 16.7 & 18.0 & 16.7 \\
Fat, E\% & 34.7 & 33.5 & 33.3 & 33.4 & 33.3 \\
Saturated fat, E\% & 13.5 & 12.8 & 12.9 & 12.8 & 12.9 \\
Monounsaturated fat, E\% & 11.6 & 11.0 & 10.9 & 11.0 & 10.9 \\
Polyunsaturated fat, E\% & 6.2 & 6.3 & 6.2 & 6.3 & 6.2 \\
Carbohydrate, E\% & 45.8 & 46.2 & 47.6 & 46.3 & 47.6 \\
Added sugar, E\% & 7.7 & 7.8 & 8.0 & 7.8 & 8.0 \\
Dietary fibre, g/MJ & 2.77 & 2.79 & 2.88 & 2.79 & 2.88 \\
Alcohol, E\% & 2.3 & 2.3 & 2.4 & 2.3 & 2.4 \\
\hline
\end{tabular}

${ }^{1}$ Dietary fibre is included in the total carbohydrate (E\%). 
Table A24. Micronutrient intake 18 to 70 year-old women in Norway, $\mathrm{n}=925$

\begin{tabular}{|c|c|c|c|c|c|}
\hline & Scenario 1 & Scenario 2 & Scenario 3 & Scenario 4 & Scenario 5 \\
\hline Energy intake, MJ & 7.99 & 7.90 & 7.99 & 7.90 & 7.99 \\
\hline Dietary fibre, $\mathrm{g}$ & 22.1 & 22.0 & 23.0 & 22.0 & 23.0 \\
\hline Vitamin A, RE & 769 & 652 & 672 & 652 & 672 \\
\hline Vitamin $D, \mu g$ & 4.88 & 5.52 & 5.09 & 5.54 & 5.09 \\
\hline Vitamin E, $\alpha$-TE & 10.01 & 10.35 & 10.31 & 10.36 & 10.31 \\
\hline Thiamine, mg & 1.37 & 1.33 & 1.33 & 1.33 & 1.33 \\
\hline Riboflavin, mg & 1.58 & 1.55 & 1.55 & 1.55 & 1.55 \\
\hline Niacin, NE & - & - & - & - & - \\
\hline Vitamin B6, mg & 1.49 & 1.61 & 1.48 & 1.62 & 1.48 \\
\hline Folate, $\mu \mathrm{g}$ & 230 & 228 & 233 & 228 & 233 \\
\hline Vitamin $B 12, \mu \mathrm{g}$ & 6.00 & 6.15 & 5.50 & 6.16 & 5.50 \\
\hline Vitamin C, mg & 109 & 109 & 114 & 109 & 113.90 \\
\hline Calcium, mg & 810 & 810 & 838 & 810 & 838 \\
\hline Phosphorus, mg & - & - & - & - & - \\
\hline Magnesium, mg & 346 & 351 & 354 & 351 & 354 \\
\hline Iron, mg & 9.90 & 9.35 & 9.57 & 9.33 & 9.57 \\
\hline Zinc, mg & - & - & - & - & - \\
\hline Copper, mg & - & - & - & - & - \\
\hline lodine $(\mu \mathrm{g})$ & - & - & - & - & - \\
\hline Selenium, $\mu \mathrm{g}$ & - & - & - & - & - \\
\hline Potassium, g & 3.37 & 3.42 & 3.42 & 3.42 & 3.42 \\
\hline
\end{tabular}

\subsubsection{Men}

Table A25. Food intake in major food groups in 18 to 70 year-old men in Norway, $n=862$

\begin{tabular}{|c|c|c|c|c|c|}
\hline & Scenario 1 & Scenario 2 & Scenario 3 & Scenario 4 & Scenario 5 \\
\hline Meat, total, g/d & 156.1 & 126.0 & 95.8 & 112.5 & 68.8 \\
\hline Red meat, $\mathrm{g} / \mathrm{d}^{1}$ & 72.2 & 70.0 & 70.0 & 43.0 & 43.0 \\
\hline White meat, $\mathrm{g} / \mathrm{d}^{1}$ & 25.8 & 56.0 & 25.8 & 69.5 & 25.8 \\
\hline Processed meat, $\mathrm{g} / \mathrm{d}^{2}$ & 58.1 & 0.0 & 0.0 & 0.0 & 0.0 \\
\hline Fish and other seafood, $\mathrm{g} / \mathrm{d}^{3}$ & 79.4 & 109.5 & 86.5 & 123.0 & 116.2 \\
\hline Egg, $g / d^{3}$ & 27.5 & 27.5 & 30.0 & 27.5 & 40.2 \\
\hline Potatoes, rice and pasta, $\mathrm{g} / \mathrm{d}^{3}$ & 105.3 & 105.3 & 114.7 & 105.3 & 154.1 \\
\hline Bread and cereals, $\mathrm{g} / \mathrm{d}^{3}$ & 250.5 & 250.5 & 272.9 & 250.5 & 366.6 \\
\hline Fat spread (on bread), $\mathrm{g} / \mathrm{d}^{3}$ & 33.3 & 33.3 & 36.3 & 33.3 & 48.7 \\
\hline Fat used in cooking, $\mathrm{g} / \mathrm{d}^{3}$ & 12.9 & 12.9 & 14.1 & 12.9 & 18.9 \\
\hline Fruit and berries (excl. juice), $\mathrm{g} / \mathrm{d}^{3}$ & 144.3 & 144.3 & 157.2 & 144.3 & 211.2 \\
\hline Juice, $g / d^{3}$ & 113.6 & 113.6 & 123.7 & 113.6 & 166.2 \\
\hline Vegetables, $\mathrm{g} / \mathrm{d}^{3}$ & 154.3 & 154.3 & 168.1 & 154.3 & 225.8 \\
\hline Milk and milk products, $\mathrm{g} / \mathrm{d}^{3}$ & 397.9 & 397.9 & 433.4 & 397.9 & 582.3 \\
\hline Cheese, $\mathrm{g} / \mathrm{d}^{3}$ & 46.0 & 46.0 & 50.1 & 46.0 & 67.3 \\
\hline Beverages, $\mathrm{g} / \mathrm{d}^{3}$ & $2,143.6$ & $2,143.6$ & $2,335.0$ & $2,143.6$ & $3,137.1$ \\
\hline Water, tea and coffee, $\mathrm{g} / \mathrm{d}^{3}$ & $1,672.1$ & $1,672.1$ & $1,821.4$ & $1,672.1$ & $2,447.1$ \\
\hline Soda and fruit nectar, $\mathrm{g} / \mathrm{d}^{3}$ & 282.0 & 282.0 & 307.2 & 282.0 & 412.7 \\
\hline Alcohol, beer and vine, $\mathrm{g} / \mathrm{d}^{3}$ & 189.5 & 189.5 & 206.4 & 189.5 & 277.3 \\
\hline Snacks, sweets, ice cream, $\mathrm{g} / \mathrm{d}^{3}$ & 90.0 & 90.0 & 98.0 & 90.0 & 131.7 \\
\hline Other, $g / d^{3}$ & 102.7 & 102.7 & 111.9 & 102.7 & 150.3 \\
\hline
\end{tabular}

${ }^{1}$ Cooked meat and minced meat, calculated $20 \%$ weight loss from raw meat

${ }^{2}$ Prepared processed meat products, not weight loss calculated

${ }^{3}$ Measured in raw weight 
Table A26. Macronutrient intake 18 to 70 year-old men in Norway, $\mathrm{n}=\mathbf{8 6 2}$

\begin{tabular}{lrrrrr}
\hline & Scenario 1 & Scenario 2 & Scenario 3 & Scenario 4 & Scenario 5 \\
\hline Protein, E\% & 17.4 & 18.4 & 16.8 & 18.5 & 16.8 \\
Fat, E\% & 34.5 & 32.9 & 32.6 & 32.4 & 32.6 \\
Saturated fat, E\% & 13.3 & 12.5 & 12.6 & 12.2 & 12.6 \\
Monounsaturated fat, E\% & 11.6 & 10.8 & 10.6 & 10.5 & 10.6 \\
Polyunsaturated fat, E\% & 6.3 & 6.4 & 6.3 & 6.5 & 6.3 \\
Carbohydrate, E\% & 45.4 & 46.0 & 47.7 & 46.3 & 47.7 \\
Added sugar, E\% & 7.5 & 7.7 & 8.0 & 7.8 & 8.0 \\
Dietary fibre, g/MJ $^{1}$ & 2.42 & 2.46 & 2.56 & 2.48 & 2.56 \\
Alcohol, E\% & 2.7 & 2.7 & 2.8 & 2.8 & 2.8 \\
\hline
\end{tabular}

${ }^{1}$ Dietary fibre is included in the total carbohydrate (E\%).

Table A27. Micronutrient intake 18 to 70 year-old men in Norway, $n=862$

\begin{tabular}{|c|c|c|c|c|c|}
\hline & Scenario 1 & Scenario 2 & Scenario 3 & Scenario 4 & Scenario 5 \\
\hline Energy intake, MJ & 10.89 & 10.72 & 10.89 & 10.64 & 10.89 \\
\hline Dietary fibre, $g$ & 26.4 & 26.4 & 27.9 & 26.4 & 27.9 \\
\hline Vitamin A, RE & 1011 & 804 & 836 & 808 & 836 \\
\hline Vitamin $D, \mu g$ & 6.69 & 7.67 & 7.07 & 8.10 & 7.07 \\
\hline Vitamin $E, \alpha-T E$ & 12.19 & 12.74 & 12.66 & 12.97 & 12.66 \\
\hline Thiamine, mg & 1.85 & 1.80 & 1.79 & 1.76 & 1.79 \\
\hline Riboflavin, mg & 2.13 & 2.10 & 2.10 & 2.10 & 2.10 \\
\hline Niacin, NE & - & - & - & - & - \\
\hline Vitamin $\mathrm{B}_{6}, \mathrm{mg}$ & 1.93 & 2.12 & 1.91 & 2.18 & 1.91 \\
\hline Folate, $\mu \mathrm{g}$ & 279 & 276 & 283 & 278 & 283 \\
\hline Vitamin $B_{12}, \mu g$ & 8.90 & 8.84 & 7.86 & 9.00 & 7.86 \\
\hline Vitamin C, mg & 104 & 104 & 110 & 104 & 110.17 \\
\hline Calcium, mg & 1038 & 1035 & 1084 & 1035 & 1084 \\
\hline Phosphorus, mg & - & - & - & - & - \\
\hline Magnesium, mg & 439 & 448 & 454 & 449 & 454 \\
\hline Iron, mg & 12.60 & 11.80 & 12.08 & 11.40 & 12.08 \\
\hline Zinc, mg & - & - & - & - & - \\
\hline Copper, mg & - & - & - & - & - \\
\hline lodine $(\mu \mathrm{g})$ & - & - & - & - & - \\
\hline Selenium, $\mu \mathrm{g}$ & - & - & - & - & - \\
\hline Potassium, g & 4.24 & 4.31 & 4.32 & 4.31 & 4.32 \\
\hline
\end{tabular}




\subsubsection{Children}

Table A28. Food intake in major food groups in 9 year-old children in Norway, $n=810$

\begin{tabular}{|c|c|c|c|c|c|}
\hline & Scenario 1 & Scenario 2 & Scenario 3 & Scenario 4 & Scenario 5 \\
\hline Meat, total, g/d & 84.5 & 65.0 & 45.5 & - & - \\
\hline Red meat, $\mathrm{g} / \mathrm{d}^{1}$ & 38.4 & 38.4 & 38.4 & - & - \\
\hline White meat, $\mathrm{g} / \mathrm{d}^{1}$ & 7.1 & 26.6 & 7.1 & - & - \\
\hline Processed meat, $\mathrm{g} / \mathrm{d}^{2}$ & 39.0 & 0.0 & 0.0 & - & - \\
\hline Fish and other seafood, $\mathrm{g} / \mathrm{d}^{3}$ & 26.6 & 46.1 & 28.1 & - & - \\
\hline Egg, $g / d^{3}$ & 9.7 & 9.7 & 10.2 & - & - \\
\hline Potatoes, rice and pasta, $\mathrm{g} / \mathrm{d}^{3}$ & 60.6 & 60.6 & 63.9 & - & - \\
\hline Bread and cereals, $g / d^{3}$ & 145.5 & 145.5 & 153.5 & - & - \\
\hline Fat spread (on bread), $\mathrm{g} / \mathrm{d}^{3}$ & 18.9 & 18.9 & 19.9 & - & - \\
\hline Fat used in cooking, $\mathrm{g} / \mathrm{d}^{3}$ & 1.6 & 1.6 & 1.7 & - & - \\
\hline Fruit and berries (excl. juice), $\mathrm{g} / \mathrm{d}^{3}$ & 78.7 & 78.7 & 83.0 & - & - \\
\hline Juice, $g / d^{3}$ & 68.6 & 68.6 & 72.4 & - & - \\
\hline Vegetables, $\mathrm{g} / \mathrm{d}^{3}$ & 65.7 & 65.7 & 69.3 & - & - \\
\hline Milk and milk products, $\mathrm{g} / \mathrm{d}^{3}$ & 422.4 & 422.4 & 445.6 & - & - \\
\hline Cheese, $g / d^{3}$ & 20.2 & 20.2 & 21.3 & - & - \\
\hline Beverages, $\mathrm{g} / \mathrm{d}^{3}$ & 587.8 & 587.8 & 620.1 & - & - \\
\hline Water, tea and coffee, $\mathrm{g} / \mathrm{d}^{3}$ & 209.7 & 209.7 & 221.2 & - & - \\
\hline Soda and fruit nectar, $\mathrm{g} / \mathrm{d}^{3}$ & 378.1 & 378.1 & 398.9 & - & - \\
\hline Alcohol, beer and vine, $\mathrm{g} / \mathrm{d}^{3}$ & 0.1 & 0.1 & 0.1 & - & - \\
\hline Snacks, sweets, ice cream, $\mathrm{g} / \mathrm{d}^{3}$ & 118.1 & 118.1 & 124.6 & - & - \\
\hline Other, $g / d^{3}$ & 120.0 & 120.0 & 126.6 & - & - \\
\hline
\end{tabular}

${ }^{1}$ Cooked meat and minced meat, calculated $20 \%$ weight loss from raw meat

${ }^{2}$ Prepared processed meat products, not weight loss calculated

${ }^{3}$ Measured in raw weight

Table A29. Macronutrient intake 9 year-old children in Norway, $\mathrm{n}=\mathbf{8 1 0}$

\begin{tabular}{lrrrrr}
\hline & Scenario 1 & Scenario 2 & Scenario 3 & Scenario 4 & Scenario 5 \\
\hline Protein, E\% & 14.1 & 15.1 & 13.6 & - & - \\
Fat, E\% & 31.4 & 29.8 & 29.4 & - & - \\
Saturated fat, E\% & 13.7 & 12.9 & 12.9 & - & - \\
Monounsaturated fat, E\% & 9.8 & 9.0 & 8.7 & - & - \\
Polyunsaturated fat, E\% & 5.7 & 5.8 & 5.7 & - & - \\
Carbohydrate, E\% & 54.5 & 55.1 & 57.0 & - & - \\
Added sugar, E\% & 16.5 & 16.8 & 17.4 & - & - \\
Dietary fibre, g/MJ & 1.79 & 1.82 & 1.89 & - & - \\
Alcohol, E\% & 0.0 & 0.0 & 0.0 & - & - \\
\hline
\end{tabular}

${ }^{1}$ Dietary fibre is included in the total carbohydrate (E\%). 
Table A30. Micronutrient intake 9 year-old children in Norway, $\mathrm{n}=810$

\begin{tabular}{|c|c|c|c|c|c|}
\hline & Scenario 1 & Scenario 2 & Scenario 3 & Scenario 4 & Scenario 5 \\
\hline Energy intake, MJ & 8.25 & 8.13 & 8.26 & - & - \\
\hline Dietary fibre, g & 14.8 & 14.8 & 15.6 & - & - \\
\hline Vitamin A, RE & 817 & 609 & 631 & - & - \\
\hline Vitamin $D, \mu g$ & 2.80 & 3.26 & 2.95 & - & - \\
\hline Vitamin $E, \alpha-T E$ & 6.07 & 6.27 & 6.30 & - & - \\
\hline Thiamine, mg & 1.10 & 1.07 & 1.08 & - & - \\
\hline Riboflavin, mg & 1.44 & 1.39 & 1.41 & - & - \\
\hline Niacin, NE & - & - & - & - & - \\
\hline Vitamin $\mathrm{B}_{6}, \mathrm{mg}$ & - & - & - & - & - \\
\hline Folate, $\mu \mathrm{g}$ & 155 & 152 & 155 & - & - \\
\hline Vitamin $B_{12}, \mu \mathrm{g}$ & - & - & - & - & - \\
\hline Vitamin C, mg & 84 & 84 & 89 & - & - \\
\hline Calcium, mg & 833 & 830 & 867 & - & - \\
\hline Phosphorus, mg & - & - & - & - & - \\
\hline Magnesium, mg & 237 & 241 & 242 & - & - \\
\hline Iron, mg & 8.80 & 8.35 & 8.38 & - & - \\
\hline Zinc, mg & - & - & - & - & - \\
\hline Copper, mg & - & - & - & - & - \\
\hline lodine $(\mu \mathrm{g})$ & - & - & - & - & - \\
\hline Selenium, $\mu \mathrm{g}$ & - & - & - & - & - \\
\hline Potassium, g & - & - & - & - & - \\
\hline
\end{tabular}

\subsubsection{Adolescents}

Table A31. Food intake in major food groups in 13 year-old adolescents in Norway, $\mathrm{n}=1005$

\begin{tabular}{|c|c|c|c|c|c|}
\hline & Scenario 1 & Scenario 2 & Scenario 3 & Scenario 4 & Scenario 5 \\
\hline Meat, total, g/d & 94.7 & 76.6 & 58.5 & 72.6 & 50.5 \\
\hline Red meat, $\mathrm{g} / \mathrm{d}^{1}$ & 51.0 & 51.0 & 51.0 & 43.0 & 43.0 \\
\hline White meat, $\mathrm{g} / \mathrm{d}^{1}$ & 7.5 & 25.6 & 7.5 & 29.6 & 7.5 \\
\hline Processed meat, $\mathrm{g} / \mathrm{d}^{2}$ & 36.2 & 0.0 & 0.0 & 0.0 & 0.0 \\
\hline Fish and other seafood, $\mathrm{g} / \mathrm{d}^{3}$ & 24.3 & 42.4 & 25.4 & 46.4 & 29.2 \\
\hline Egg, $g / d^{3}$ & 8.8 & 8.8 & 9.2 & 8.8 & 10.6 \\
\hline Potatoes, rice and pasta, $\mathrm{g} / \mathrm{d}^{3}$ & 67.2 & 67.2 & 70.2 & 67.2 & 80.7 \\
\hline Bread and cereals, $\mathrm{g} / \mathrm{d}^{3}$ & 145.8 & 145.8 & 152.4 & 145.8 & 175.1 \\
\hline Fat spread (on bread), $g / d^{3}$ & 15.1 & 15.1 & 15.8 & 15.1 & 18.1 \\
\hline Fat used in cooking, $\mathrm{g} / \mathrm{d}^{3}$ & 2.9 & 2.9 & 3.0 & 2.9 & 3.5 \\
\hline Fruit and berries (excl. juice), $\mathrm{g} / \mathrm{d}^{3}$ & 58.2 & 58.2 & 60.8 & 58.2 & 69.9 \\
\hline Juice, $g / d^{3}$ & 86.4 & 86.4 & 90.3 & 86.4 & 103.8 \\
\hline Vegetables, $\mathrm{g} / \mathrm{d}^{3}$ & 69.5 & 69.5 & 72.6 & 69.5 & 83.5 \\
\hline Milk and milk products, $\mathrm{g} / \mathrm{d}^{3}$ & 369.9 & 369.9 & 386.6 & 369.9 & 444.3 \\
\hline Cheese, $\mathrm{g} / \mathrm{d}^{3}$ & 24.1 & 24.1 & 25.2 & 24.1 & 29.0 \\
\hline Beverages, $\mathrm{g} / \mathrm{d}^{3}$ & 771.8 & 771.8 & 806.6 & 771.8 & 927.1 \\
\hline Water, tea and coffee, $\mathrm{g} / \mathrm{d}^{3}$ & 270.8 & 270.8 & 283.0 & 270.8 & 325.3 \\
\hline Soda and fruit nectar, $\mathrm{g} / \mathrm{d}^{3}$ & 500.6 & 500.6 & 523.2 & 500.6 & 601.4 \\
\hline Alcohol, beer and vine, $\mathrm{g} / \mathrm{d}^{3}$ & 0.4 & 0.4 & 0.4 & 0.4 & 0.5 \\
\hline Snacks, sweets, ice cream, $\mathrm{g} / \mathrm{d}^{3}$ & 134.1 & 134.1 & 140.1 & 134.1 & 161.1 \\
\hline Other, $\mathrm{g} / \mathrm{d}^{3}$ & 134.3 & 134.3 & 140.4 & 134.3 & 161.3 \\
\hline
\end{tabular}

${ }^{1}$ Cooked meat and minced meat, calculated $20 \%$ weight loss from raw meat

${ }^{2}$ Prepared processed meat products, not weight loss calculated

${ }^{3}$ Measured in raw weight 
Table A32. Macronutrient intake 13 year-old adolescents in Norway, $\mathrm{n}=1005$

\begin{tabular}{lrrrrr}
\hline & Scenario 1 & Scenario 2 & Scenario 3 & Scenario 4 & Scenario 5 \\
\hline Protein, E\% & 14.2 & 15.1 & 13.8 & 15.1 & 13.8 \\
Fat, E\% & 30.6 & 29.4 & 29.0 & 29.3 & 29.0 \\
Saturated fat, E\% & 13.5 & 12.8 & 12.9 & 12.7 & 12.9 \\
Monounsaturated fat, E\% & 9.7 & 9.1 & 8.8 & 9.1 & 8.8 \\
$\quad$ Polyunsaturated fat, E\% & 5.3 & 5.3 & 5.2 & 5.3 & 5.2 \\
Carbohydrate, E\% & 55.2 & 55.5 & 57.3 & 55.6 & 57.3 \\
$\quad$ Added sugar, E\% & 18.3 & 18.5 & 19.1 & 18.5 & 19.1 \\
$\quad$ Dietary fibre, g/MJ & 1.67 & 1.69 & 1.74 & 1.69 & 1.74 \\
Alcohol, E\% & 0.0 & 0.0 & 0.0 & 0.0 & 0.0 \\
\hline
\end{tabular}

${ }^{1}$ Dietary fibre is included in the total carbohydrate (E\%).

Table A33. Micronutrient intake 13 year-old adolescents in Norway, $n=1005$

\begin{tabular}{|c|c|c|c|c|c|}
\hline & Scenario 1 & Scenario 2 & Scenario 3 & Scenario 4 & Scenario 5 \\
\hline Energy intake, MJ & 8.86 & 8.77 & 8.87 & 8.76 & 8.87 \\
\hline Dietary fibre, $\mathrm{g}$ & 14.8 & 14.8 & 15.4 & 14.8 & 15.4 \\
\hline Vitamin A, RE & 774 & 574 & 590 & 576 & 590 \\
\hline Vitamin $D, \mu g$ & 2.53 & 3.00 & 2.64 & 3.10 & 2.64 \\
\hline Vitamin E, $\alpha$-TE & 6.87 & 7.08 & 7.09 & 7.11 & 7.09 \\
\hline Thiamine, mg & 1.13 & 1.10 & 1.10 & 1.09 & 1.10 \\
\hline Riboflavin, mg & 1.42 & 1.38 & 1.38 & 1.37 & 1.38 \\
\hline Niacin, NE & - & - & - & - & - \\
\hline Vitamin $\mathrm{B}_{6}, \mathrm{mg}$ & - & - & - & - & - \\
\hline Folate, $\mu \mathrm{g}$ & 162 & 160 & 163 & 161 & 163 \\
\hline Vitamin $B_{12}, \mu g$ & - & - & - & - & - \\
\hline Vitamin C, mg & 89 & 89 & 93 & 89 & 93.01 \\
\hline Calcium, mg & 858 & 856 & 885 & 857 & 885 \\
\hline Phosphorus, mg & - & - & - & - & - \\
\hline Magnesium, mg & 247 & 251 & 251 & 251 & 251 \\
\hline Iron, mg & 9.40 & 9.12 & 9.14 & 9.00 & 9.14 \\
\hline Zinc, mg & - & - & - & - & - \\
\hline Copper, mg & - & - & - & - & - \\
\hline lodine $(\mu \mathrm{g})$ & - & - & - & - & - \\
\hline Selenium, $\mu \mathrm{g}$ & - & - & - & - & - \\
\hline Potassium, g & - & - & - & - & - \\
\hline
\end{tabular}




\subsection{Sweden}

\subsubsection{Women}

Table A34. Food intake in major food groups in 18 to 75 year-old women in Sweden, $\mathbf{n = 9 8 2}$

\begin{tabular}{lrrrrr} 
& Scenario 1 & Scenario 2 & Scenario 3 & Scenario 4 & Scenario 5 \\
\hline Meat, total, g/d & 88.7 & 77.1 & 65.5 & 75.5 & 60.4 \\
Red meat, g/d & 45.3 & 45.3 & 45.3 & 42 & 42 \\
White meat, g/d & 20.2 & 31.8 & 20.2 & 33.5 & 20.2 \\
Processed meat, g/d & 23.2 & 0 & 0 & 0 & 0 \\
Fish, g/d & 43.3 & 54.9 & 44.1 & 56.6 & 44.2 \\
Egg, g/d & 21.3 & 21.3 & 21.6 & 21.3 & 21.7 \\
Potatoes, rice and pasta, g/d & 140 & 140 & 143 & 140 & 143 \\
Bread and cereals, g/d & 122 & 122 & 124 & 122 & 125 \\
Fat spread (on bread), g/d & 9.7 & 9.7 & 9.8 & 9.7 & 9.9 \\
Fat used in cooking, g/d & - & - & - & - & - \\
Fruit (excl. juice), g/d & 138 & 138 & 140 & 138 & 140 \\
Juice, g/d & 53 & 53 & 54 & 53 & 54 \\
Vegetables, g/d & 138 & 138 & 140 & 138 & 141 \\
Milk and milk products, g/d & 249 & 249 & 253 & 249 & 254 \\
Cheese, g/d & 25.7 & 25.7 & 26.1 & 25.7 & 26.2 \\
Beverages, g/d & 1,310 & 1,310 & 1,331 & 1,310 & 1,337 \\
Water, tea and coffee, g/d & 1,115 & 1,115 & 1,134 & 1,115 & 1,138 \\
Soda and fruit nectar, g/d & 97 & 97 & 98 & 97 & 99 \\
Alcohol, beer and vine, g/d & 98 & 98 & 99 & 98 & 100 \\
Savoury, sweets, ice cream, g/d & 84 & 84 & 85 & 84 & 85 \\
Other, g/d & 128 & 128 & 130 & 128 & 131 \\
\hline
\end{tabular}

Table A35. Macronutrient intake in 18 to 75 year-old women in Sweden, $\mathbf{n = 9 8 2}$

\begin{tabular}{lrrrrr}
\hline & Scenario 1 & Scenario 2 & Scenario 3 & Scenario 4 & Scenario 5 \\
\hline Protein, E\% & 16.8 & 16.7 & 16.1 & 16.7 & 16.0 \\
Fat, E\% & 34.4 & 34.2 & 33.9 & 34.2 & 33.7 \\
$\quad$ Saturated fat, E\% & 13.1 & 12.9 & 12.9 & 12.9 & 12.8 \\
$\quad$ Monounsaturated fat, E\% & 12.9 & 12.8 & 12.6 & 12.7 & 12.5 \\
Polyunsaturated fat, E\% & 5.7 & 5.8 & 5.7 & 5.8 & 5.7 \\
Carbohydrate, E\% & 46.0 & 46.0 & 47.1 & 46.0 & 47.1 \\
$\quad$ Added sugar, E\% ${ }^{1}$ & 8.2 & 8.2 & 8.4 & 8.2 & 8.4 \\
Dietary fibre, g/MJ $^{2}$ & 2.6 & 2.6 & 2.6 & 2.6 & 2.6 \\
Alcohol, E\% & 2.8 & 2.8 & 2.9 & 2.8 & 2.9 \\
\hline
\end{tabular}

${ }^{1}$ Sucrose.

${ }^{2}$ Dietary fibre is included in the total carbohydrate (E\%). 
Table A36. Micronutrient intake in 18 to 75 year-old women in Sweden, $\mathbf{n = 9 8 2}$

\begin{tabular}{|c|c|c|c|c|c|}
\hline & Scenario 1 & Scenario 2 & Scenario 3 & Scenario 4 & Scenario 5 \\
\hline Energy intake, MJ & 7.4 & 7.4 & 7.4 & 7.4 & 7.4 \\
\hline Dietary fibre, $\mathrm{g}$ & 18.8 & 18.9 & 19.2 & 19 & 19.2 \\
\hline Vitamin A, RE & 824 & 802 & 794 & 799 & 786 \\
\hline Vitamin D, $\mu \mathrm{g}$ & 6.4 & 7.1 & 6.4 & 7.2 & 6.4 \\
\hline Vitamin $E, \alpha-T E$ & 11.6 & 11.7 & 11.7 & 11.7 & 11.7 \\
\hline Thiamine, mg & 1.1 & 1.1 & 1.09 & 1.1 & 1.08 \\
\hline Riboflavin, mg & 1.4 & 1.4 & 1.39 & 1.38 & 1.38 \\
\hline Niacin, NE & 31.3 & 31 & 29.7 & 30.9 & 29.4 \\
\hline Vitamin $\mathrm{B}_{6}, \mathrm{mg}$ & 1.83 & 1.83 & 1.79 & 1.84 & 1.78 \\
\hline Folate, $\mu \mathrm{g}$ & 253 & 252 & 256 & 252 & 255 \\
\hline Vitamin $B_{12}, \mu g$ & 5 & 5.3 & 4.8 & 5.3 & 4.8 \\
\hline Vitamin C, mg & 95.7 & 95.5 & 98.0 & 95.5 & 98.0 \\
\hline Calcium, mg & 818 & 820 & 837 & 820 & 836 \\
\hline Phosphorus, mg & 1,241 & 1,241 & 1,230 & 1,241 & 1,223 \\
\hline Magnesium, mg & 305 & 306 & 308 & 306 & 307 \\
\hline Iron, mg & 9.5 & 9.4 & 9.3 & 9.4 & 9.2 \\
\hline Zinc, mg & 9.5 & 9.3 & 9.1 & 9.2 & 9.0 \\
\hline Copper, mg & - & - & - & - & - \\
\hline lodine $(\mu \mathrm{g})$ & - & - & - & - & - \\
\hline Selenium, $\mu \mathrm{g}$ & 41.7 & 43.5 & 40.8 & 43.8 & 40.5 \\
\hline Potassium, g & 2885 & 2883 & 2890 & 2883 & 2878 \\
\hline
\end{tabular}

\subsubsection{Men}

Table A37. Food intake in major food groups in 18 to 75 year-old men in Sweden, $n=762$

\begin{tabular}{lrrrrr}
\hline & Scenario 1 & Scenario 2 & Scenario 3 & Scenario 4 & Scenario 5 \\
\hline Meat, total, g/d & 136.9 & 115.2 & 93.4 & 101 & 65.4 \\
Red meat, g/d & 73.5 & 70 & 70 & 42 & 42 \\
White meat, g/d & 23.4 & 45.2 & 23.4 & 59,2 & 23.4 \\
Processed meat, g/d & 40 & 0 & 0 & 0 & 0 \\
Fish, g/d & 50.6 & 72.4 & 51.6 & 86,4 & 52.2 \\
Egg, g/d & 19 & 19 & 19 & 19 & 20 \\
Potatoes, rice and pasta, g/d & 232 & 232 & 236 & 232 & 239 \\
Bread and cereals, g/d & 158 & 158 & 161 & 158 & 163 \\
Fat spread (on bread), g/d & 13 & 13 & 13 & 13 & 13.5 \\
Fat used in cooking, g/d & - & - & - & - & - \\
Fruit (excl. juice), g/d & 97 & 97 & 99 & 97 & 100 \\
Juice, g/d & 65 & 65 & 66 & 65 & 67 \\
Vegetables, g/d & 113 & 113 & 115 & 113 & 116 \\
Milk and milk products, g/d & 289 & 289 & 295 & 289 & 298 \\
Cheese, g/d & 25.3 & 25.3 & 25.8 & 25.3 & 26.1 \\
Beverages, g/d & 1,312 & 1,312 & 1,338 & 1,312 & 1,355 \\
Water, tea and coffee, g/d & 958 & 958 & 977 & 958 & 989 \\
Soda and fruit nectar, g/d & 135 & 135 & 138 & 135 & 140 \\
Alcohol, beer and vine, g/d & 219 & 219 & 223 & 219 & 226 \\
Savoury, sweets, ice cream, g/d & 85 & 85 & 87 & 85 & 88 \\
Other, g/d & 169 & 169 & 172 & 169 & 175 \\
\hline
\end{tabular}


Table A38. Macronutrient intake in 18 to 75 year-old men in Sweden, $\mathbf{n = 7 6 2}$

\begin{tabular}{lrrrrr}
\hline & Scenario 1 & Scenario 2 & Scenario 3 & Scenario 4 & Scenario 5 \\
\hline Protein, E\% & 17.0 & 17.0 & 16.1 & 16.9 & 15.5 \\
Fat, E\% & 33.9 & 33.6 & 32.9 & 33.3 & 32.2 \\
Saturated fat, E\% & 13 & 12.7 & 12.6 & 12.5 & 12.4 \\
Monounsaturated fat, E\% & 12.7 & 12.6 & 12.2 & 12.4 & 11.8 \\
Polyunsaturated fat, E\% & 5.4 & 5.6 & 5.4 & 5.6 & 5.4 \\
Carbohydrate, E\% & 45.2 & 45.2 & 46.6 & 45.8 & 47.7 \\
Added sugar, E\% ${ }^{1}$ & 7.2 & 7.2 & 7.4 & 7.2 & 7.6 \\
Dietary fibre, E/MJ ${ }^{2}$ & 2.3 & 2.4 & 2.3 & 2.4 & 2.4 \\
Alcohol, E\% & 3.9 & 3.9 & 4.1 & 3.9 & 4.2 \\
\hline
\end{tabular}

${ }^{1}$ Sucrose.

${ }^{2}$ Dietary fibre is included in the total carbohydrate (E\%).

Table A39. Micronutrient intake in 18 to 75 year-old men in Sweden, $\mathbf{n = 7 6 2}$

\begin{tabular}{|c|c|c|c|c|c|}
\hline & Scenario 1 & Scenario 2 & Scenario 3 & Scenario 4 & Scenario 5 \\
\hline Energy intake, MJ & 9.4 & 9.4 & 9.4 & 9.3 & 9.4 \\
\hline Dietary fibre, $g$ & 21.3 & 21.7 & 21.9 & 21.9 & 22.4 \\
\hline Vitamin A, RE & 806 & 793 & 792 & 785 & 784 \\
\hline Vitamin $D, \mu g$ & 7.6 & 8.9 & 7.6 & 9.7 & 7.6 \\
\hline Vitamin $E, \alpha$-TE & 13.2 & 13.4 & 13.3 & 13.5 & 13.5 \\
\hline Thiamine, mg & 1.4 & 1.4 & 1.3 & 1.4 & 1.3 \\
\hline Riboflavin, mg & 1.69 & 1.67 & 1.66 & 1.66 & 1.65 \\
\hline Niacin, NE & 40.9 & 40.4 & 38.2 & 40.1 & 36.5 \\
\hline Vitamin $\mathrm{B}_{6}, \mathrm{mg}$ & 2.3 & 2.3 & 2.3 & 2.3 & 2.2 \\
\hline Folate, $\mu \mathrm{g}$ & 266 & 266 & 271 & 267 & 275 \\
\hline Vitamin $B_{12}, \mu g$ & 6 & 6.6 & 5.8 & 6.9 & 5.6 \\
\hline Vitamin C, mg & 92.7 & 92.6 & 95.7 & 92.5 & 98.0 \\
\hline Calcium, mg & 944 & 948 & 971 & 950 & 992 \\
\hline Phosphorus, mg & 1,543 & 1,545 & 1,518 & 1,546 & 1,505 \\
\hline Magnesium, mg & 365 & 366 & 368 & 366 & 371 \\
\hline Iron, mg & 11.5 & 11.3 & 11.1 & 11.1 & 10.8 \\
\hline Zinc, mg & 12.4 & 11.9 & 11.5 & 11.6 & 11.0 \\
\hline Copper, mg & - & - & - & - & - \\
\hline lodine ( $\mu \mathrm{g}$ ) & - & - & - & - & - \\
\hline Selenium, $\mu \mathrm{g}$ & 50.4 & 53.9 & 48.7 & 56.2 & 47.7 \\
\hline Potassium, g & 3413 & 3412 & 3401 & 3410 & 3402 \\
\hline
\end{tabular}




\subsubsection{Children}

Table A40. Food intake in major food groups in 4 year olds and $2^{\text {nd }}$ graders (age 8) in Sweden, $n=1479$

\begin{tabular}{lrrrrr} 
& Scenario 1 & Scenario 2 & Scenario 3 & Scenario 4 & Scenario 5 \\
\hline Meat, total, g/d & 122.6 & 104 & 85.5 & 90 & 57.5 \\
Red meat, g/d & 79.4 & 70 & 70 & 42 & 42 \\
White meat, g/d & 15.5 & 34 & 15.5 & 48 & 15.5 \\
Processed meat, g/d & 27.8 & 0 & 0 & 0 & 0 \\
Fish, g/d & 18.3 & 36.9 & 18.7 & 50.9 & 18.9 \\
Egg, g/d & 5.7 & 5.7 & 5.8 & 5.7 & 5.9 \\
Potatoes, rice and pasta, g/d & 175 & 175 & 178 & 175 & 181 \\
Bread and cereals, g/d & 129 & 129 & 131 & 129 & 133 \\
Fat spread (on bread), g/d & 12.8 & 12.8 & 13.0 & 12.8 & 13.2 \\
Fat used in cooking, g/d & - & - & - & - & - \\
Fruit (excl. juice), g/d & 108 & 108 & 110 & 108 & 111 \\
Juice, g/d & 68 & 68 & 69 & 68 & 70 \\
Vegetables, g/d & 61 & 61 & 62 & 61 & 63 \\
Milk and milk products, g/d & 453 & 453 & 462 & 453 & 468 \\
Cheese, g/d & 9.4 & 9.4 & 9.6 & 9.4 & 9.7 \\
Beverages, g/d & 384.2 & 384.2 & 391.3 & 384.2 & 396.3 \\
Water, tea and coffee, g/d & 155 & 155 & 158 & 155 & 160 \\
Soda and fruit nectar, g/d & 227 & 227 & 231 & 227 & 234 \\
Alcohol, beer and vine, g/d & 2.2 & 2.2 & 2.3 & 2.2 & 2.3 \\
Savoury, sweets, ice cream, g/d & 115 & 115 & 118 & 115 & 119 \\
Other, g/d & 100 & 100 & 107 & 100 & 114 \\
\hline
\end{tabular}

Table A41. Macronutrient intake 4 year olds and $2^{\text {nd }}$ graders (age 8) in Sweden, $n=1479$

\begin{tabular}{lrrrrr}
\hline & Scenario 1 & Scenario 2 & Scenario 3 & Scenario 4 & Scenario 5 \\
\hline Protein, E\% & 15 & 14.8 & 15.3 & 14.7 & 15.5 \\
Fat, E\% & 31.6 & 31.1 & 32.1 & 30.9 & 32.6 \\
Saturated fat, E\% & 14.3 & 14 & 14.6 & 13.8 & 14.8 \\
Monounsaturated fat, E\% & 11.4 & 11.1 & 11.6 & 11.0 & 11.7 \\
Polyunsaturated fat, E\% & 3.7 & 3.8 & 3.7 & 3.9 & 3.8 \\
Carbohydrate, E\% & 53.4 & 53.5 & 54.4 & 53.5 & 55.2 \\
$\quad$ Added sugar, E\% & 13.0 & 13.1 & 13.3 & 13.1 & 13.5 \\
Dietary fibre, g/MJ $^{2}$ & 1.8 & 1.8 & 1.8 & 1.8 & 1.8 \\
Alcohol, E\% & 0.008 & 0.008 & 0.008 & 0.008 & 0,008 \\
\hline
\end{tabular}

1 Sucrose.

2 Dietary fibre is included in the total carbohydrate (E\%). 
Table A42. Micronutrient intake 4 year olds and $2^{\text {nd }}$ graders (age 8) in Sweden, $n=1479$

\begin{tabular}{|c|c|c|c|c|c|}
\hline & Scenario 1 & Scenario 2 & Scenario 3 & Scenario 4 & Scenario 5 \\
\hline Energy intake, MJ & 7.1 & 7.0 & 7.1 & 7.0 & 7.1 \\
\hline Dietary fibre, $g$ & 12.6 & 12.5 & 12.8 & 12.4 & 13.0 \\
\hline Vitamin A, RE & 733 & 708 & 747 & 689 & 757 \\
\hline Vitamin $D, \mu g$ & 4.4 & 5.2 & 4.5 & 5.8 & 4.5 \\
\hline Vitamin $E, \alpha-T E$ & 6.0 & 6.2 & 6.2 & 6.3 & 6.3 \\
\hline Thiamine, mg & 1.14 & 1.14 & 1.15 & 1.10 & 1.18 \\
\hline Riboflavin, mg & 1.5 & 1.5 & 1.6 & 1.5 & 1.6 \\
\hline Niacin, NE & 24 & 23 & 24 & 22 & 24 \\
\hline Vitamin $\mathrm{B}_{6}, \mathrm{mg}$ & 1.5 & 1.5 & 1.5 & 1.5 & 1.5 \\
\hline Folate, $\mu \mathrm{g}$ & 176 & 174 & 179 & 173 & 181 \\
\hline Vitamin $B_{12}, \mu g$ & 4.4 & 4.8 & 4.5 & 5.0 & 5.6 \\
\hline Vitamin C, mg & 76 & 75 & 77 & 75 & 78 \\
\hline Calcium, mg & 912 & 913 & 929 & 913 & 942 \\
\hline Phosphorus, mg & 1,138 & 1,130 & 1,160 & 1,124 & 1,176 \\
\hline Magnesium, mg & 231 & 230 & 236 & 229 & 239 \\
\hline Iron, mg & 8.3 & 8.0 & 8.4 & 7.9 & 8.6 \\
\hline Zinc, mg & 8.7 & 8.3 & 8.9 & 8.0 & 9.0 \\
\hline Copper, mg & - & - & - & - & - \\
\hline lodine $(\mu \mathrm{g})$ & - & - & - & - & - \\
\hline Selenium, $\mu \mathrm{g}$ & 28.3 & 30.1 & 28.9 & 31.5 & 29.2 \\
\hline Potassium, g & 2574 & 2555 & 2623 & 2540 & 2660 \\
\hline
\end{tabular}

\subsubsection{Adolescents}

Table A43. Food intake in major food groups in adolescents $\left(5^{\text {th }}\right.$ graders, age 11$)$ in Sweden, $n=1016$

\begin{tabular}{lrrrrr}
\hline & Scenario 1 & Scenario 2 & Scenario 3 & Scenario 4 & Scenario 5 \\
\hline Meat, total, g/d & 135,3 & 110.9 & 86.5 & 96.9 & 58.5 \\
Red meat, g/d & 89 & 70 & 70 & 42 & 42 \\
White meat, g/d & 16.5 & 40.9 & 16.5 & 54.9 & 16.5 \\
Processed meat, g/d & 29.8 & 0 & 0 & 0 & 0 \\
Fish, g/d & 18.5 & 42.9 & 18.9 & 56.9 & 19.1 \\
Egg, g/d & 4.5 & 4.5 & 4.6 & 4.5 & 4.7 \\
Potatoes, rice and pasta, g/d & 200 & 200 & 205 & 200 & 208 \\
Bread and cereals, g/d & 103 & 103 & 106 & 103 & 107 \\
Fat spread (on bread), g/d & 12 & 12 & 12 & 12 & 12 \\
Fat used in cooking, g/d & - & - & - & - & - \\
Fruit (excl. juice), g/d & 68 & 68 & 69 & 68 & 70 \\
Juice, g/d & 77 & 77 & 78 & 77 & 79 \\
Vegetables, g/d & 53 & 53 & 54 & 53 & 55 \\
Milk and milk products, g/d & 423 & 423 & 432 & 423 & 438 \\
Cheese, g/d & 11.2 & 11.2 & 11.4 & 11.2 & 11.6 \\
Beverages, g/d & 456.7 & 456.7 & 466.7 & 456.7 & 472.8 \\
Water, tea and coffee, g/d & 208 & 208 & 212 & 208 & 215 \\
Soda and fruit nectar, g/d & 244 & 244 & 250 & 244 & 253 \\
Alcohol, beer and vine, g/d & 4.7 & 4.7 & 4.7 & 4.7 & 4.8 \\
Savoury, sweets, ice cream, g/d & 102.2 & 102.2 & 104.6 & 102.2 & 105.6 \\
Other, g/d & 112 & 112 & 127 & 112 & 135 \\
\hline
\end{tabular}


Table A44. Macronutrient intake in adolescents $\left(5^{\text {th }}\right.$ graders, age 11) in Sweden, $n=1016$

\begin{tabular}{lrrrrr}
\hline & Scenario 1 & Scenario 2 & Scenario 3 & Scenario 4 & Scenario 5 \\
\hline Protein, E\% & 15.7 & 15.6 & 16 & 15.2 & 16.2 \\
Fat, E\% & 31.5 & 31.4 & 32.3 & 30.7 & 32.7 \\
Saturated fat, E\% & 14.0 & 13.9 & 14.4 & 13.5 & 14.6 \\
Monounsaturated fat, E\% & 11.5 & 11.4 & 11.8 & 11.0 & 12.0 \\
Polyunsaturated fat, E\% & 3.7 & 3.9 & 3.8 & 4.0 & 3.9 \\
Carbohydrate, E\% & 52.8 & 52.9 & 54.0 & 52.8 & 54.7 \\
Added sugar, E\% & 12.3 & 12.3 & 12.6 & 12.4 & 12.7 \\
$\quad$ Dietary fibre, g/MJ" & 1.8 & 1.7 & 1.8 & 1.8 & 1.8 \\
Alcohol, E\% & 0.02 & 0.02 & 0.02 & 0.02 & 0.02 \\
\hline
\end{tabular}

${ }^{1}$ Sucrose.

${ }^{2}$ Dietary fibre is included in the total carbohydrate (E\%).

Table A45. Micronutrient intake in adolescents $\left(5^{\text {th }}\right.$ graders, age 11) in Sweden, $n=1016$

\begin{tabular}{|c|c|c|c|c|c|}
\hline & Scenario 1 & Scenario 2 & Scenario 3 & Scenario 4 & Scenario 5 \\
\hline Energy intake, MJ & 7.4 & 7.3 & 7.4 & 7.3 & 7.4 \\
\hline Dietary fibre, $g$ & 12.6 & 12.6 & 12.9 & 12.5 & 13.0 \\
\hline Vitamin A, RE & 632 & 610 & 646 & 580 & 654 \\
\hline Vitamin $D, \mu g$ & 4.1 & 5.2 & 4.2 & 5.7 & 4.2 \\
\hline Vitamin $\mathrm{E}, \alpha-\mathrm{TE}$ & 5.8 & 5.7 & 5.9 & 6.0 & 6.0 \\
\hline Thiamine, mg & 1.2 & 1.2 & 1.2 & 1.1 & 1.2 \\
\hline Riboflavin, mg & 1.5 & 1.5 & 1.5 & 1.5 & 1.6 \\
\hline Niacin, NE & 26 & 25 & 26 & 24 & 27 \\
\hline Vitamin $\mathrm{B}_{6}, \mathrm{mg}$ & 1.5 & 1.6 & 1.6 & 1.5 & 1.6 \\
\hline Folate, $\mu \mathrm{g}$ & 174 & 174 & 178 & 172 & 181 \\
\hline Vitamin $\mathrm{B}_{12}, \mu \mathrm{g}$ & 4.4 & 4.8 & 4.4 & 5.0 & 4.5 \\
\hline Vitamin C, mg & 63 & 63 & 65 & 63 & 65 \\
\hline Calcium, mg & 874 & 876 & 894 & 876 & 905 \\
\hline Phosphorus, mg & 1,169 & 1,172 & 1,196 & 1,153 & 1,210 \\
\hline Magnesium, mg & 239 & 239 & 244 & 237 & 247 \\
\hline Iron, mg & 8.3 & 8.1 & 8.5 & 7.8 & 8.6 \\
\hline Zinc, mg & 9.5 & 9.2 & 9.7 & 8.6 & 9.8 \\
\hline Copper, mg & - & - & - & - & - \\
\hline lodine $(\mu \mathrm{g})$ & - & - & - & - & - \\
\hline Selenium, $\mu \mathrm{g}$ & 29.7 & 32.6 & 30.4 & 33.3 & 30.7 \\
\hline Potassium, g & 2,603 & 2,600 & 2,662 & 2,564 & 2,695 \\
\hline
\end{tabular}


Nordic Council of Ministers

Ved Stranden 18

DK-1061 Copenhagen K

www.norden.org

\section{Nutritional evaluation of lowering consumption of meat and meat products in the Nordic context}

The World Cancer Research Fund (WCRF) recommended in 2007 that consumer intake of red meat is minimized and processed meat eliminated. The recommendation was based on a systematic review of the available literature on the association between meat consumption and cancer. The recommendation to individuals was to ingest less than 500 grams of red meat per weeks, and very little - if anything - processed meats. In a new study, National Food Institute has assessed the nutritional consequences from living the recommendations of the WCRF, in Norway, Sweden, Finland and Denmark. The current consumption of meat in the Nordic countries is not far from the level WCRF has proposed on an individual level. The study also shows that it will have no significant nutritional consequences to reduce the intake of meat to the recommended, neither when it comes to red meat nor processed meat. 